\title{
FURTHER EXPERIMENTS ON THE EFFECT OF HEAT ON THE EGGS OF CUMINGIA.
}

MARGARET MORRIS HOSKINS,

University and Bellevue Hospital Medical College.

I. Introduction.--If the eggs of the mollusc Cumingia tellinoides are heated during the prophase of the first maturation division, the formation of the polar body is prevented. The nuclear division continues, giving rise to two daughter nuclei, both of which are retained in the egg. In the unfertilized egg these nuclei fuse, so that the egg is in fact fertilized by the polar nucleus. The course of the development which follows this self-fertilization has already been described (Morris, 'I 7 ). Since the publication of that study, experiments similar to those producing artificial parthenogenesis have been made on fertilized eggs. It was found that if eggs are heated immediately after insemination they do not form polar bodies, but proceed to the first cleavage at the end of the warming. As these eggs should contain a triploid instead of a diploid number of chromosomes, it was thought that a study of them and a comparison with dispermic eggs might yield interesting results. Theoretically, of course, the polar nucleus is equivalent to a sperm nucleus, and either of these is equivalent to the egg nucleus. The suppression of maturation gives a chance for an interesting comparison between the sperm and polar nuclei. Besides the experiments in which maturation was suppressed, a control series of experiments was made to distinguish the effects of heating from those of the retention of the polar nucleus. In this series, the fertilized eggs were heated after they had completed the formation "of polar bodies. Any abnormalities found in these eggs would obviously be the result of the heat alone.

A cytological study of eggs from the different sets of experiments has been made and is presented in the following pages.

II. Material and Methods.-The technique of the experiments is extremely simple and hardly varies at all from that used in 260 
producing artificial parthenogenesis. A small flask of sea water is partially immersed in a beaker of water, and warmed over a flame. The eggs are put into this flask, and can easily be kept at any desired temperature for an hour or more. The temperature most frequently used was that which had been most success$\mathrm{ful}$ in inducing parthenogenetic development, $32^{\circ}$ to $34^{\circ} \mathrm{C}$. The length of the exposure was different, however, for while the unfertilized eggs are not injured by being kept at this temperature for sixty, or even ninety minutes, the fertilized eggs appear more sensitive and should not be heated for more than thirty-five or forty minutes. In one series of experiments the eggs were placed in the warm water within five minutes after insemination; in the others they were watched until maturation was complete, and transferred to the flask before the pronuclei had united.

Eggs were preserved from the various experiments at different intervals, and a large amount of normal material was also preserved. Bouin's fluid was used as a fixative and the eggs were embedded in paraffin in the usual way. The sections were cut ten microns in thickness and stained with iron hematoxylin.

III. Cytological Study.-A few points in the normal and parthenogenetic development of Cumingia should be reviewed here for the sake of clearness. The haploid number of chromosomes is eighteen; they are very distinct in the first maturation spindle. There is no reason to suppose that the exact diploid number is not present in the first cleavage spindle of normally fertilized eggs, but owing to the form of the chromosomes, accurate counting is impossible. The long thin threads are so much intertwined, that individuals cannot be distinguished. In the parthenogenetic egg, however, the case is different. Here the chromosomes of the first cleavage are small and very definite bodiesand it is possible to count them. Since the chromatin of the egg has not undergone reduction, one would expect to find thirtysix chromosomes in the first cleavage. Such is not the case, however; the number is variable, but always greater than thirtysix. Fifty to sixty of these small masses of chromatin are present, and it is evident that they do not represent individuals of the normal chromosome group. Under the experimental conditions a new distribution of the chromatic material has taken place, 
and an abnormal number of chromosomes is formed. It is not possible to determine whether the mass of chromatic material rep esented in one of these plates of chromosomes is exactly equal to that of a normal cleavage plate, but on theoretical grounds it was assumed that such is the case.

(b) Suppression of Maturation in Fertilized Eggs.-As has been said the fertilized eggs in which maturation is to be suppressed are heated within five minutes after their insemination. At this time, the polar spindle has moved to the periphery of the egg, but the formation of the polar body itself has not begun. The sperm head is within the egg, but has not been transformed into a vesicular pronucleus. The first stage that is of interest in eggs preserved from these experiments is the anaphase represented in Fig. I. In this it will be seen that a division of the eighteen bivalent chromosomes has taken place, and that the daughter chromosomes are moving somewhat irregularly to the poles of the spindle, while the sperm head is beginning to enlarge to form a vesicle.

A later stage of this nuclear division is shown in Fig. 2. Here the chromosomes have begun to form vesicles preparatory to passing into the resting stage. It will be seen from Fig. I that although the division of the chromosomes is complete, the migration of the daughter chromosomes to the poles of the spindle is somewhat irregular, and it is owing to this fact that we do not find two perfectly definite groups of vesicles in such a stage as Fig. 2 represents. In this figure the male pronucleus is also to be seen; it is well advanced in its development, and apparently has not been injured by the heat.

Further development of the resting nuclei is seen in Fig. 3. Here two daughter nuclei are found, with a third small vesicle which would undoubtedly have fused ultimately with them, as there is no evidence that any such vesicles are ever left out. In this stage the male pronucleus had developed still farther, and it is probable that the aster represented in the figure is of male origin.

Fig. 4 represents the final stage of the suppression of the polar body. In this, the two daughter nuclei formed from the chromosomes of the polar spindle have fused completely. The male pronucleus has reached a large size and lies closely apposed 
to the egg nucleus. The aster has already divided and the spindle is forming before the male and female pronuclei have fused. In some cases, apparently, the pronuclei do not unite at all; and one finds such a prophase of the first cleavage as that represented in Fig. 5. Here two skeins of chromatin are present in the spindle, and the figure shows what it is important to note, namely, that even if the pronuclei do not unite before cleavage, all chromatic material is included in the formation of the chromosomes of the first cleavage spindle.

We can trace, then, in eggs which have been heated immediately after fertilization, a suppression of maturation which leads to the formation of two daughter nuclei within the egg. Further, we can trace the union of both these nuclei with the male pronucleus, leading to the formation of a cleavage spindle which should contain eighteen chromosomes from the sperm and thirty-six from the egg. This suppression of maturation is exactly like the process which has been seen to take place in the unfertilized eggs, in which, owing to the absence of the sperm, the result is a diploid instead of a triploid amount of chromatin.

(c) The First Cleavage of Heated Eggs.-The first cleavage spindle forms normally in the eggs which have been heated immediately after insemination. Before its formation the eggs have been returned to cooler sea water, so that conditions surrounding them are normal during the division. The important variation from the usual condition is seen in the chromatic part of the figure. Theoretically, of course, there should be fifty-four chromosomes, but as a matter of fact there are sometimes fewer, sometimes more than this number. Figs. 6 to 9 show plates of chromosomes from such eggs, in which the numbers are 44,48 , 50 and $6 \mathrm{I}$, respectively.

It is in a comparison of these plates with those from parthenogenetic, normal and dispermic eggs that the greatest interest is to be found. The equatorial plates of the first cleavage of normal eggs show how much the form of the chromosomes is modified by the experimental treatment. In the normal eggs (Figs. Io and II), one finds long threads so much twisted about each other that accurate counting of them is impossible. This is the case also in the dispermic egg, as shown in Fig. I2. It is evident that 
more chromosomes are present here than in the normal egg, but the exact numerical relations cannot be determined. The most interesting comparison to be made is with the parthenogenetic egg. Here, as has been said, the chromosomes are so distinct that they can be counted, and the number is about the same as that found in fertilized eggs in which the polar bodies have been suppressed. Figs. I3 and I4 are from the first cleavage of parthenogenetic eggs, in which the numbers of the chromosomes are 46 and 47 respectively. In other cases as many as sixty-one chromosomes have been found (Morris, 'I7). The general shape of the bodies is similar in parthenogenetic and in heated fertilized eggs; spherical bodies and short thick rods are found instead of the normal threads. A striking difference is seen, however, in the size of the individual chromosomes, which is considerably greater in the fertilized than in the parthenogenetic egg. This is most clearly respresented in text-figure $\mathrm{I}$, in which the chromosomes are arranged in rows, graded according to size. $A$ represents the chromosomes of the parthenogenetic egg, $C$ those of the fertilized egg in which maturation has been suppressed. The smallest members of the two groups are about equal in size, but almost half of those in the fertilized egg are larger than the largest from the parthenogenetic one. A natural explanation of this difference in size is suggested by the fact that while the suppression of the polar body gives the parthenogenetic egg a diploid amount of chromatin, the same process makes the fertilized egg triploid. As the number of chromosomes is the same in the two cases, we might expect their size to be greater in the egg that contains the larger amount of chromatin. This was, in fact, the explanation given in a preliminary report (Morris, 'I 7 ), but further experiments have shown that it is not entirely correct.

A control series of experiments was made in which eggs were subjected to heat after the formation of the polar bodies had been completed. In these, the effects of heat are shown, separated from any effect of the retention of the polar nucleus. The comparison of the parthenogenetic eggs with those that have been fertilized and heated before maturation leads one to expect that eggs heated after maturation will show cleavage chromosomes exactly like those of parthenogenetic egg, since both are 
diploid and have been exposed to heat. When, however, examination of the preserved material is made, an unexpected condition is found. As in other eggs which have been heated, the chromosomes are fifty-five to sixty-five in number, but instead of being like those of the diploid parthenogenetic egg in size, they are not to be distinguished from those of the triploid egg. The reader is referred again to text-figure $I$ in which the nuclear condition of the three kinds of eggs is shown. $A$ is the parthenogenetic egg with thirty-six chromosomes incorporated into its cleavage nucleus, $B$ the normal one also containing thirty-six, and $C$ the triploid egg with fifty-four chromosomes. The range of size of the chromosomes is about the same in both kinds of fertilized eggs $(B$ and $C$ ) notwithstanding the different amounts of chromatin present in them. Plates of the eggs heated after maturation are shown in Figs. I5, I6 and 17 , the numbers of the chromosomes being 55, 65, and 66 respectively.

(d) The Value of the Polar Body. - The unexpected size relation of the cleavage chromosomes suggests the possibility that the chromatin of the polar nucleus is not, as a matter of fact, active. If that were the case, the parthenogenetic egg would be actually haploid, and both fertilized eggs diploid, and this would explain the condition illustrated in the text-figure. It must be remembered, however, that the polar nucleus is like the egg nucleus in appearance, and that the two vesicles fuse without any evidence of elimination of nuclear material. Dead chromatin is sometimes found in the cytoplasm of other kinds of eggs under abnormal conditions, but no such masses of chromatin are found in the material preserved from these experiments. Since this is so, it is difficult to believe that the polar nucleus, which was formed from perfectly normal daughter chromosomes, suffers complete degeneration. This is especially true when one reviews the experiments (Morris, 'I7) by which it was shown that the retention of the polar nucleus in unfertilized eggs is followed by normal cleavage; while those eggs from which it is extruded are unable to develop.

Study of the later stages of the development of heated eggs confirms the belief that the polar nucleus is an active element in 
development. In the cleavage which occurs about three hours after fertilization, one finds that the chromatin has returned to the normal condition. The number of the chromosomes can no longer be distinguished accurately, as they are small and crowded
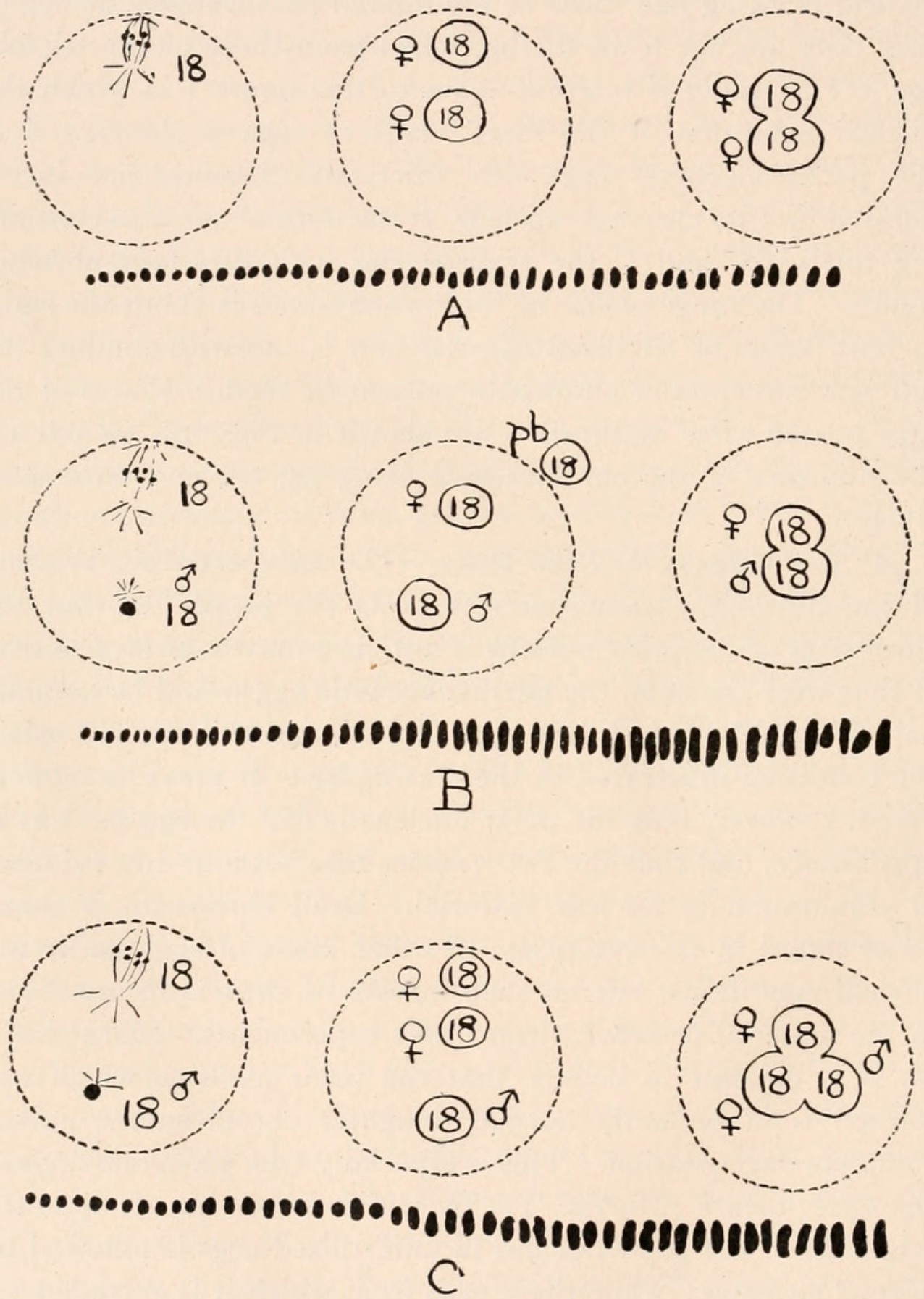

FIG. I. Diagrams showing the nuclear conditions and the chromosomes of eggs heated at different periods. $A$, heated before fertilization (parthenogenetic); $B$, heated after fertilization and maturation; $C$, heated after fertilization and before maturation. 
together in the spindle. Fig. 18 is from a fertilized egg in which maturation has been suppressed, Fig. I9 from a normal one, and Fig. 20 from one which was heated after its polar bodies had been formed. A comparison of the three figures shows that there are approximately the same number of chromosomes in the plates represented in 19 and 20 , while 18 shows a larger number. This is in accordance with the belief that the polar nucleus contributes normal chromosomes to the egg.

Further evidence is given by a study of the resting nuclei. Boveri ('05) has shown that the surface area of a resting nucleus is proportional to the number of chromosomes in it, and this fact is frequently used in determining the relative amounts of chromatin when the cleavage chromosomes cannot be counted. In the present instance, the four cell stage of the various types of egg has been selected for comparison. Here we can be sure of comparing equivalent nuclei, as the size and position of the cells makes them easily recognizable. It will be remembered that the cleavage in Cumingia is not equal. The first division separates a small cell $A B$ from a larger one, $C D$. Then follows a division of $A B$ giving rise to a three-cell stage; and next $C D$ divides. In the four-cell stage $A, B$ and $C$ are approximately equal, while $D$ is larger than any of them. In the normal egg, shown in text-figure $2, A$, the nuclei of all four cells are equal. Fig. 2, $B$, shows a parthenogenetic egg, with nuclei like those of the normal one; and such nuclei are also found in eggs heated after maturation, as shown in Fig. 2, C. All these eggs contain the diploid amount of chromatin, which is not actually changed by the heating, and, as far as can be judged from the resting nuclei, the chromatin supplied by the polar nucleus is equivalent to that supplied by the sperm. Similarity is also found among triploid eggs, whether these contain an extra sperm or a suppressed polar nucleus. Text-figure $2, D$, shows a dispermic egg with two multinucleate cells and one nucleus abnormally large. Text-figure 2, E, represents a fertilized egg in which the polar nucleus was retained; here also are two multinucleate cells. In $F$ which is from an egg of the same sort, the cells are not multinucleate, but two of the nuclei are above the normal size.

(e) The Size and Number of the Chromosomes.-From the 
evidence given above I believe we may conclude that the parthenogenetic egg contains a diploid amount of chromatin, while the fertilized egg in which maturation has been suppressed is triploid. It is evident then that the size of the chromosomes in heated eggs is determined by some other factor than the amount
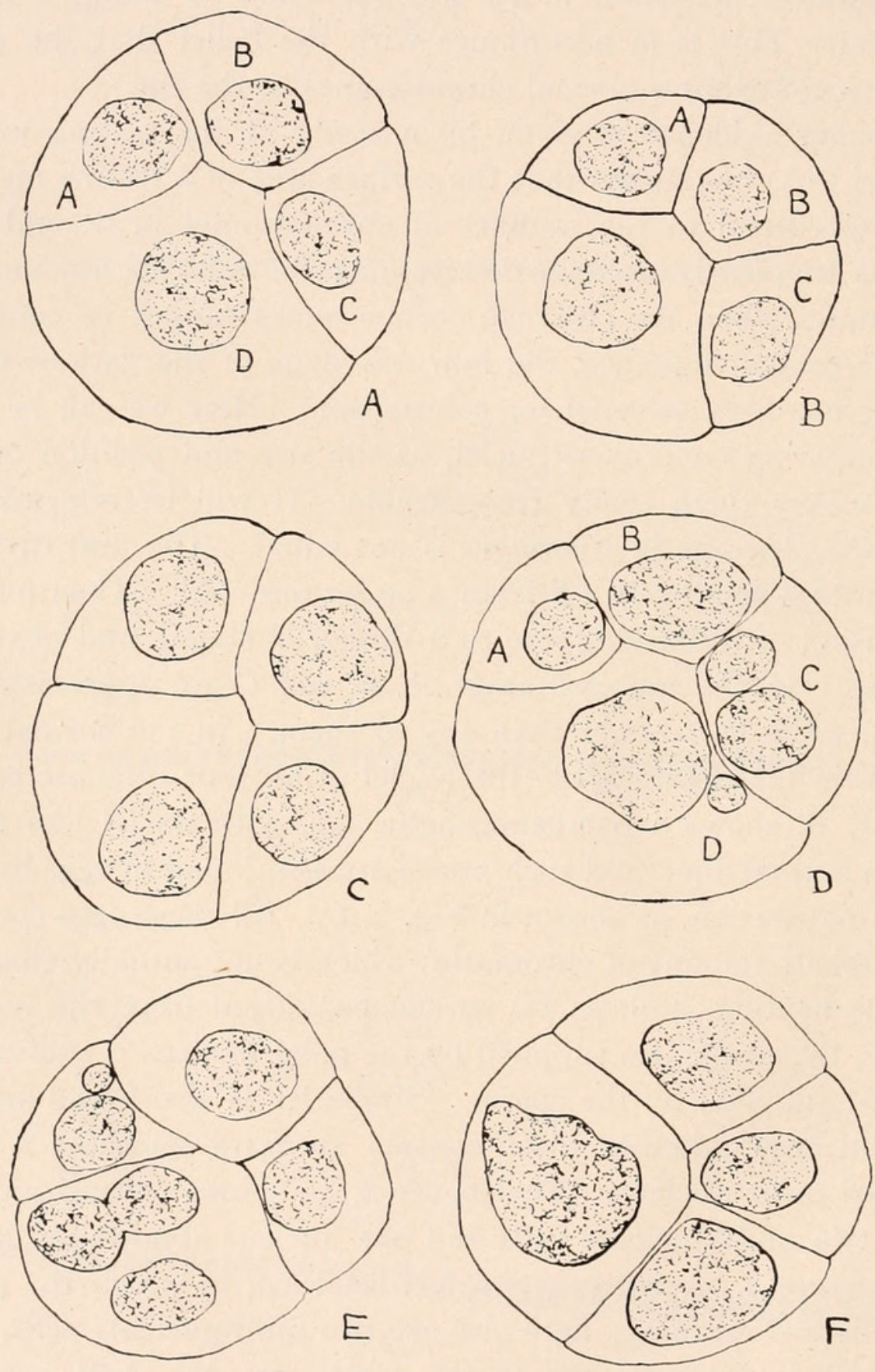

FIG. 2. $A$, normal egg (diploid); $B$, parthenogenetic egg (diploid); $C$, fertilized egg heated after maturation (diploid); $D$, dispermic egg (triploid); $E$ and $F$, fertilized egg heated immediately after insemination (triploid). 
of nuclear material that is present in them. If this were not so, the chromosomes of the fertilized egg heated after maturation would be like those of the parthenogenetic egg, instead of like those of the triploid one. Various other facts indicate that the appearance of these equatorial plates is not a reliable measure of the amount of chromatin present. Compare, for instance, Figs. I5 and I7. There are ten more chromosomes in the second plate than in the first, but the increase in number has evidently not been accomplished by the subdivision of some members of the first group for the average size of the bodies is greater in the plate which contains the larger number. Compare Fig. I7 with Fig. Io also. Fertilization and maturation were normal in both these eggs, so that they undoubtedly contained the same amount of chromatin, but it seems as if there were more in the figure from the egg which has been heated. There is, in fact, no increase in amount, for in later stages the chromatin returns to the normal condition (Figs. I9 and 20).

Apparently, in heated eggs, we have an abnormal condition of aggregation of the chromatin, varying somewhat in individual cases. The variations observed in the number and size of the chromosomes are due to differing degrees of susceptibility to heat on the part of the eggs. When the susceptibility is slight, there is an increase in the number of bodies formed from the chromatin; when it is greater, there is an apparent increase in the amount of this material. It may be noted that the slighter abnormality is found in eggs heated before fertilization. At this period few eggs are destroyed by the heat, even if the exposure is prolonged to ninety minutes. After fertilization and maturation have taken place, it is difficult to warm the eggs for even thirty minutes without killing a large number; and it is in the chromosomes of these eggs that the greatest degree of abnormality is observed.

\section{Discussion.}

In I9Io, Jordan studied the normal cytology of Cumingia, and concluded that in this animal the chromosomes are not persistent and individual cell organs. He based his conclusion on two facts; first, that they cannot be followed through the resting stage of the cell cycle; and second, that they undergo 
changes of form during the development of the egg. At first sight, the evidence given in this paper seems to agree with Jordan's conclusion. If the persistence or recurrence of a definite group of chromosomes at each mitosis is essential to proving them individuals, the bodies in Cumingia cannot be so designated, since an entirely abnormal arrangement of the chromatin may be substituted for the usual group without injury to the egg. This use of the word "individuality" (implying unity and a separate, definite existence) has been made by many writers, and has led to much argument and confusion. It is not, however, the sense, in which all supporters of the theory of the individuality of the chromosomes have applied it. As McClung ('I 7 ) for instance, uses it, it means that each chromosome is qualitatively different from the others in the group- "a single thing of a given kind." The essential point is that the chromatin is "differentially organized and linearly arranged," and the chromosomes are aggregates of this substance, individual in the sense that they have specific characters. This theory is broad enough so that Hance's work (I9I8) really supports it. Hance finds, both in Enothera scintillans and in the pig, certain fragmented chromosomes. The parts of chromosomes behave like normal bodies in the various stages of mitosis, and such facts would be in opposition to the narrower view of the individuality of the chromosomes. Hance, concludes "If the theory of the individuality of the chromosomes can only recognize a strict morphological continuity then the chromosomes in Scintillans lose their individuality through breaking up. If the theory is broader in its scope and admits an individuality not only of whole chromosomes, but of the chromatin or chromomeres, the scintillans situation falls within its limits."

The conditions found in Cumingia give no information with regard to the organization of the chromatin or the individuality of chromomeres. All that can be established from them is that the aggregation of the chromatin into definite bodies is subject to a certain amount of variation under normal conditions, and to very great alterations under the influence of heat. This behavior is entirely consistent, so far as I can see, with the belief that the chromatin is definitely organized and that the normal chromo- 
somes are qualitatively different from each other. On the other hand the facts are not incompatible with the opposing view that the chromatin is a homogeneous substance, which condenses at mitosis into masses devoid of individuality.

\section{Summary.}

I. If the eggs of Cumingia are subjected to heat immediately after fertilization, they do not form polar bodies. The chromosomes of the first polar spindle divide and two resting nuclei are formed. These nuclei fuse with each other and with the male pronucleus, giving rise to a cleavage nucleus which contains a triploid amount of chromatin.

2. The equatorial plates of these eggs show forty-five to sixty chromosomes. About the same number has been found in the cleavage of parthenogenetic (diploid) eggs; but there the individual bodies are smaller than they are in the triploid eggs.

3. If fertilized eggs are heated after they have formed polar bodies, the equatorial plates of their first cleavage contain fiftyfive to sixty-five chromosomes. These are equal in size to those of a triploid egg.

4. Study of later stages (resting nuclei and equatorial plates) shows that the chromatin of the polar nucleus is active, and approximately equivalent to that of a male pronucleus.

5. The size and number of the chromosomes in heated eggs is not dependent on the amount of chromatin that is present. They vary with the susceptibility of the egg to heat.

6. The conditions described are not in opposition to the theory of the individuality of the chromosomes, if that theory is given a broad interpretation.

Boveri, Th.

\section{BIBLIOGRAPHY.}

'o5 Zellen Studien, V. Jena, I905.

Hance, Robert T.

'r8a Somatic Chromosome Variations in the Evening Primrose. Enothera scintillans. Genetics.

'r8b The Diploid Chromosome Complexes of the Pig (Sus scrofa) and Their Variations, Jour. Morph., Vol. 30, No. I.

Jordan, H. E.

'ro A Cytological Study of the Egg of Cumingia with Special Reference to the History of the Chromosomes and the Centrosome, Arch. fur. Zellforsch., Vol. 4. 
McClung, C. E.

'r7 The Multiple Chromosomes of Hesperotettix and Mermiria (Orthoptera). Jour. Morph., Vol. 29, No. 2.

Morris, Margaret.

'r7a A Cytological Study of Artificial Parthenogenesis in Cumingia, Jour. Exp. Zoöl., Vol. 22, No. I.

'r $7 \mathbf{b}$ Influence of Heat on the Eggs of Cumingia, Proc. Am. Assoc. Anat. Anat. Rec., Vol. I I, No. 6. 



\section{EXPLANATION OF PLATE I.}

All the figures on this plate are from fertilized eggs, heated immediately after insemination,

FIG. I. First polar, spindle, anaphase, male pronucleus at the left.

FIG. 2. First polar, spindle, telophase. Male pronucleus at the right.

FIG. 3. Daughter nuclei from maturation division, male pronucleus below.

FIG. 4. Diploid female pronucleus and normal male pronucleus uniting.

FIG. 5. Prophase, first cleavage. 

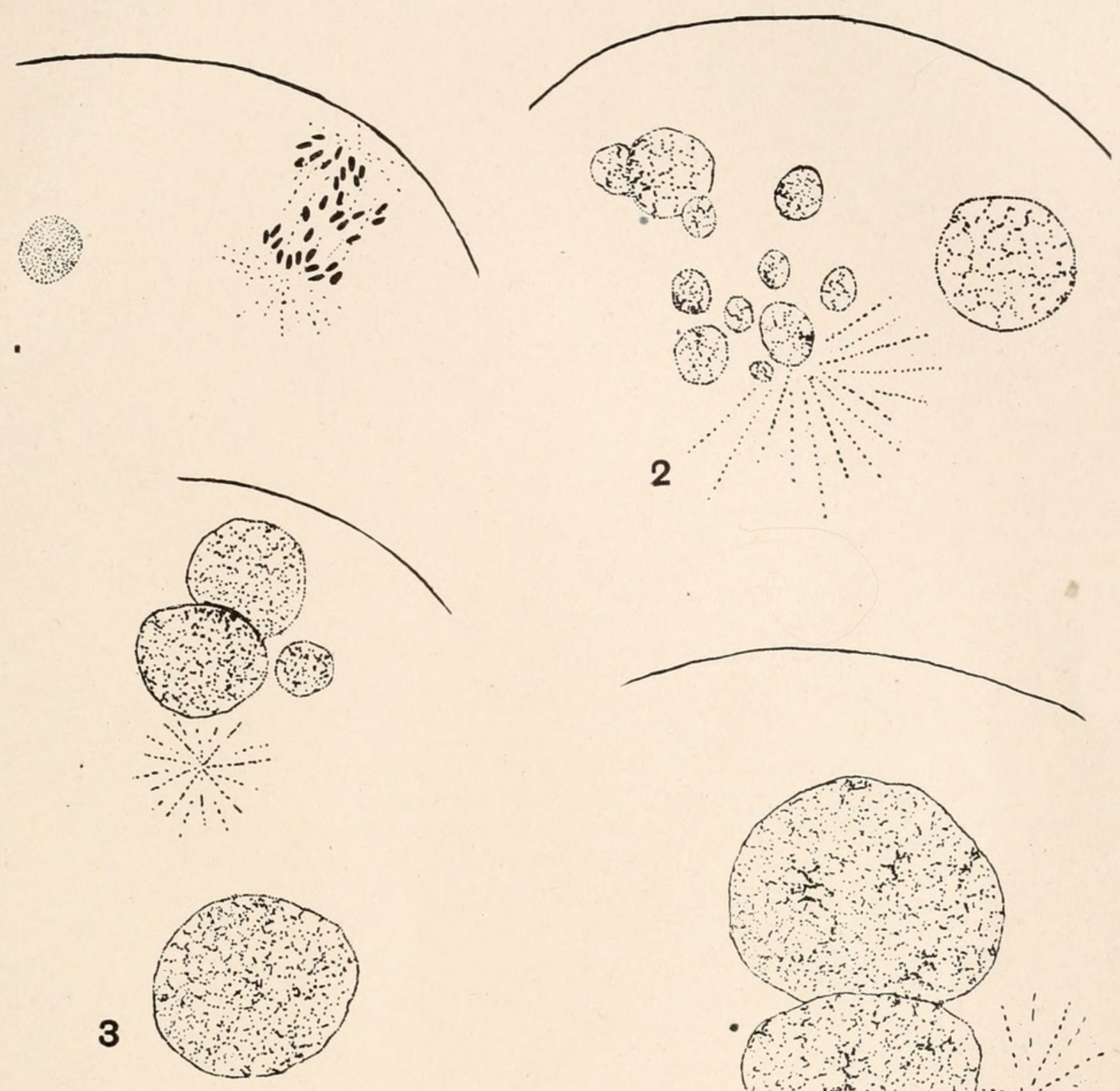

2
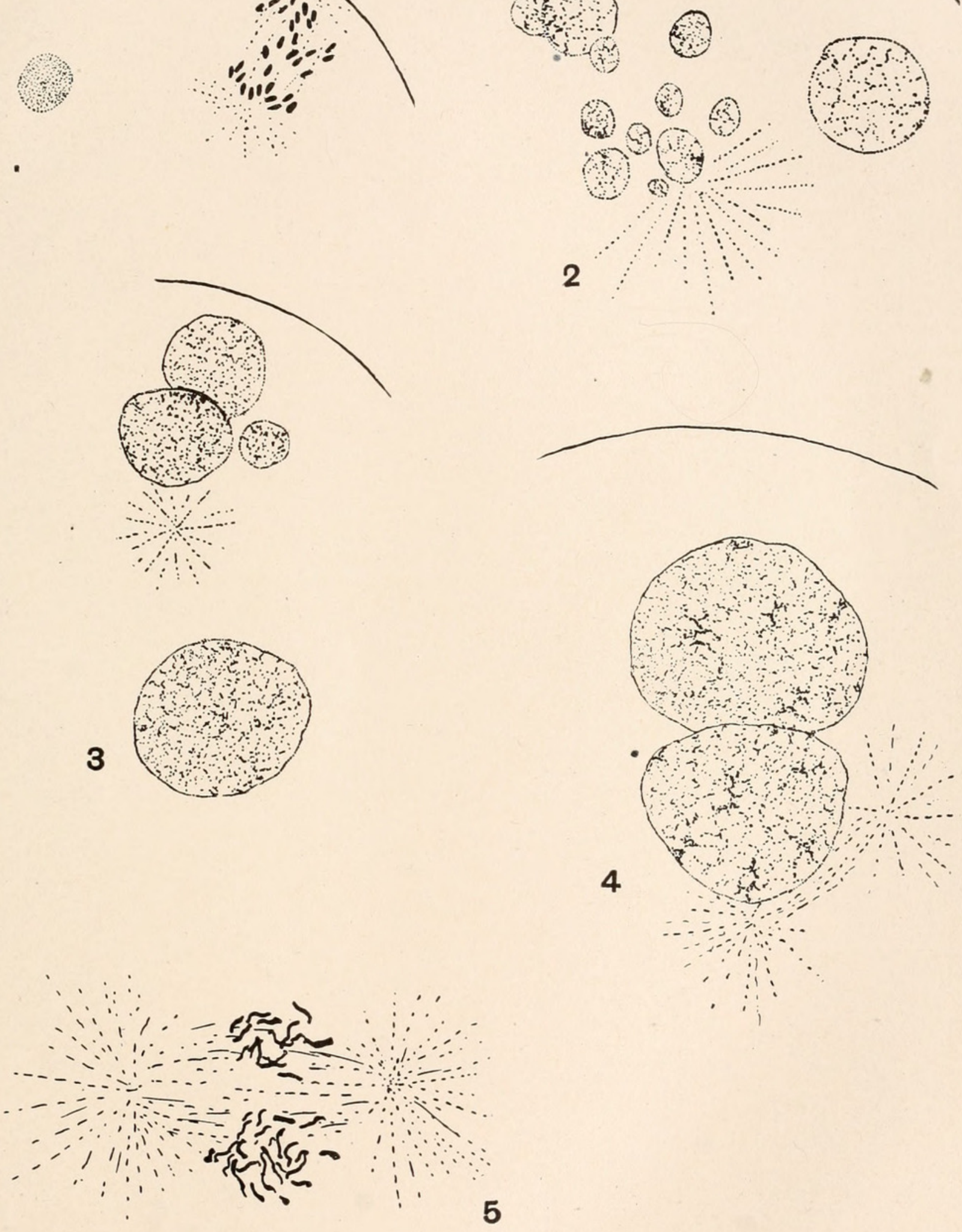




\section{EXPLANATION OF PLATE II.}

FIGs. 6, 7, 8, 9. Equatorial plates of first cleavage of eggs, heated immediately after insemination (triploid).

Figs. IO, II. Chromosomes from first cleavage of normal eggs.

FIG: I2. Chromosomes from first cleavage of dispermic egg.

FIG. I3, I4. Equatorial plates of first cleavage of parthenogenetic eggs (diploid).

FIGs. I5, I6, I7. Equatorial plates of first cleavage of eggs heated after maturation was completed (diploid).

FIG. I8. Chromosomes from an egg heated immediately after insemination. Egg preserved three hours after fertilization.

FIG. I9. Chromosomes from a normal egg, preserved three hours after fertilization.

FIG. 20. Chromosomes from an egg heated after maturation was completed. Egg preserved three hours after fertilization.

FIG. 2I. First cleavage (anaphase) of an egg heated after maturation was completed. 

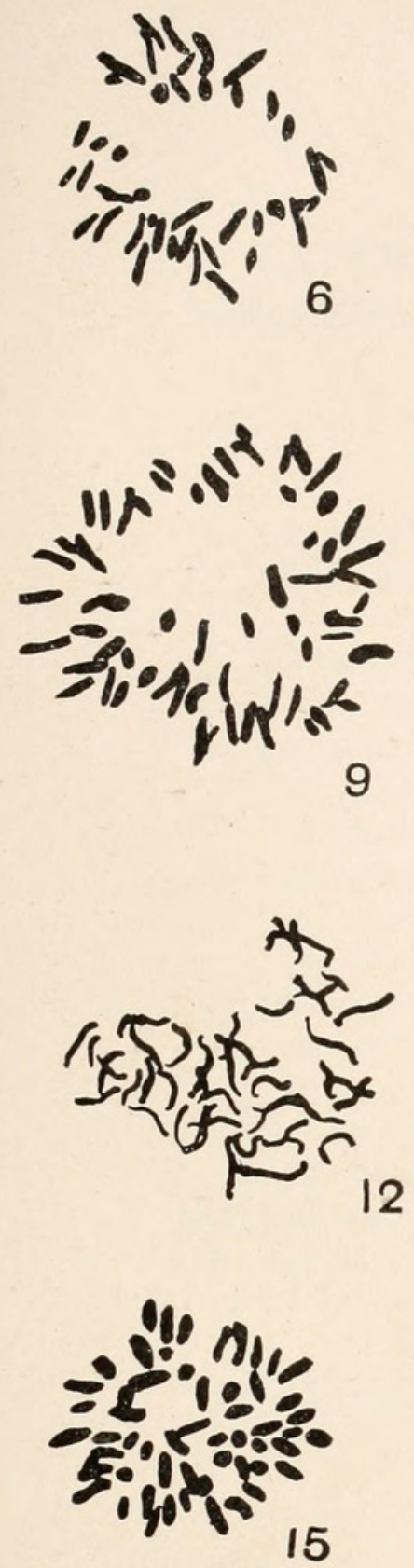
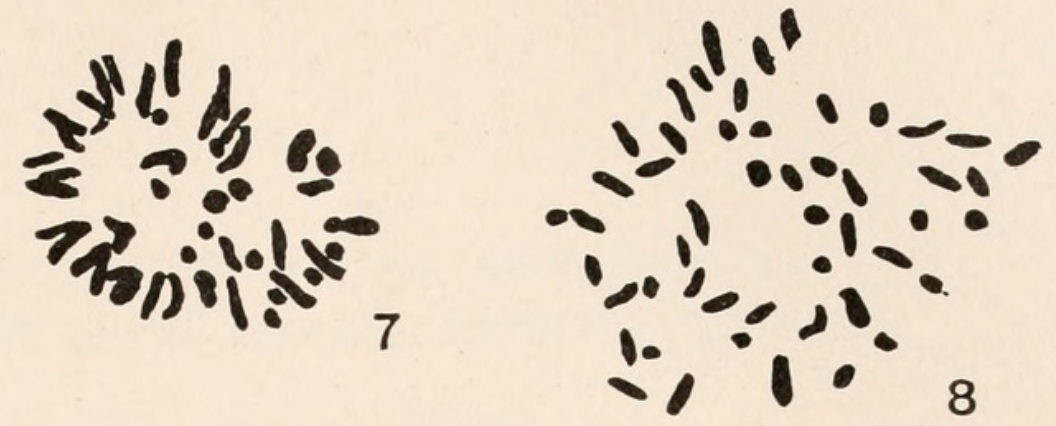
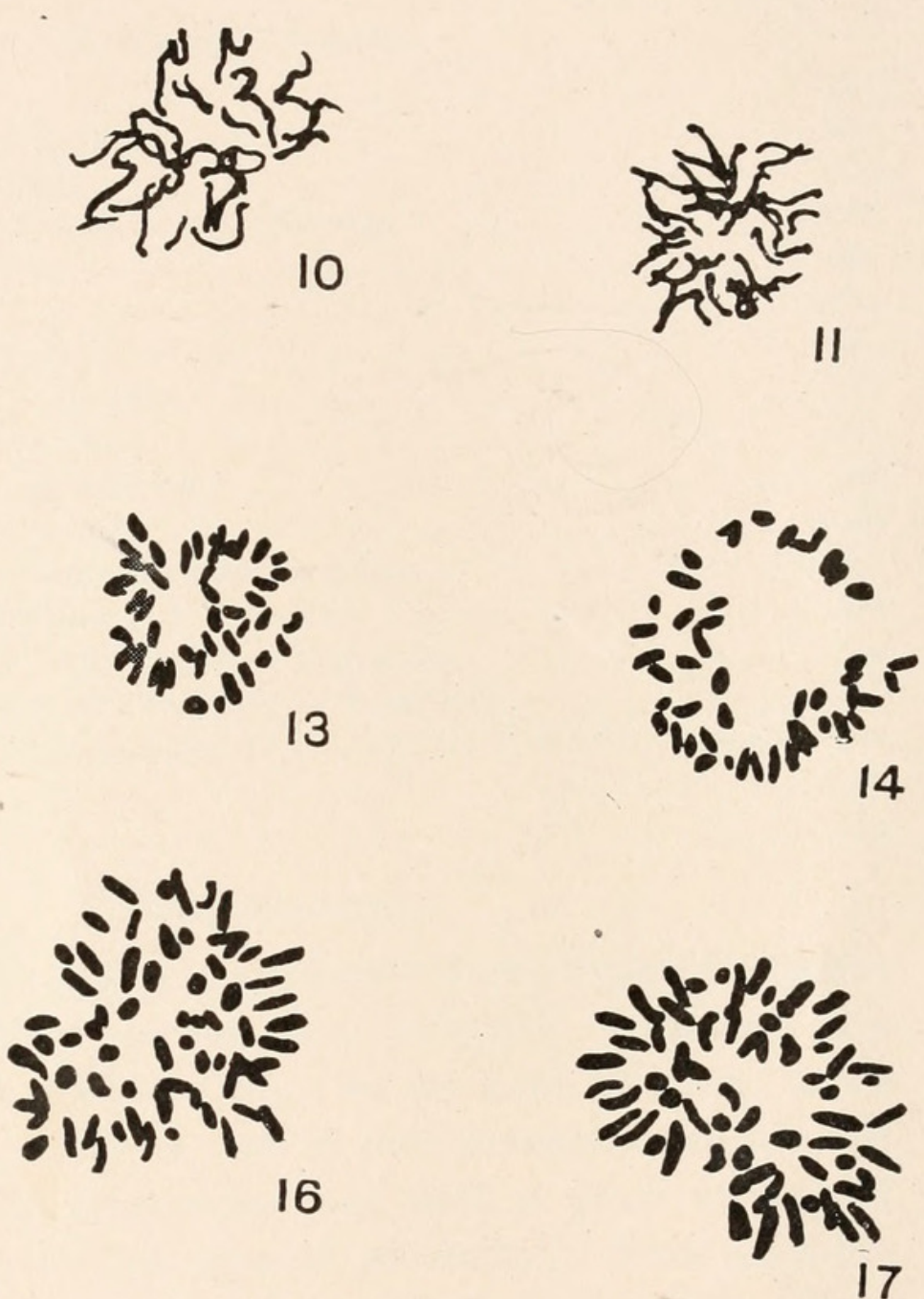

18

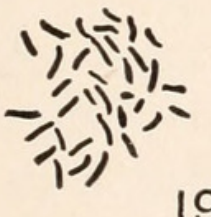

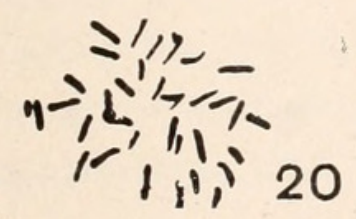

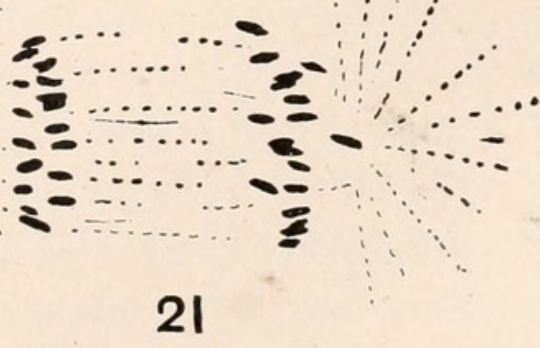





\title{
AN EXPERIMENTAL STUDY OF ACCLIMATION TO TEMPERATURE IN PLANARIA DOROTOCEPHALA.
}

\author{
ELLINOR HELENE BEHRE.
}

TABle of Contents.

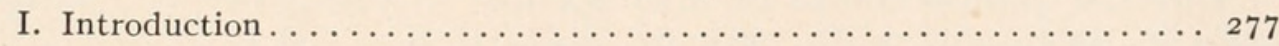

Summary of the Literature. . . . . . . . . . . . . 277

Purposes of the Paper ......................... 279

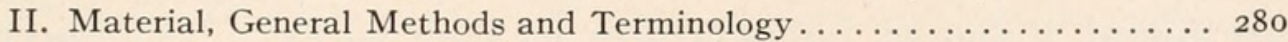

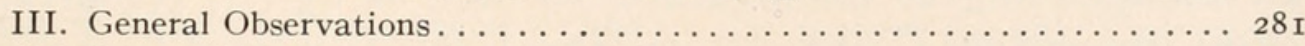

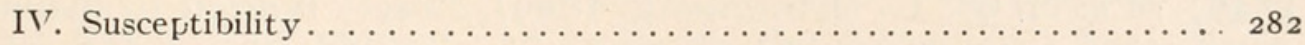

A. Jong Time Acclimation. . . . . . . . . . . . 284

B. Short Time Acclimation . . . . . . . . . . . . . 287

V. Carbon Dioxire Production . . . . . . . . . . . . . . . . 293

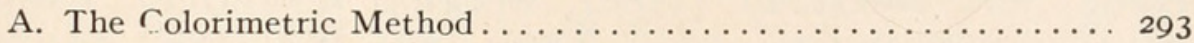

B. The Biometer Method. . . . . . . . . . . . . . . . . . 298

$\checkmark$ I. Influence of Temperature on Head-Frequency . . . . . . . . 300

A. Direct effect of altered temperature............. 300

I. During the Entire Period of Regulation. . . . . . . . . 300

2. During the First Few Hours of Regulation . . . . . . . . . 305

B. An Analysis of Acclimation by the Method of Head-Frequency. . 308

VII. Discussion . . . . . . . . . . . . . . . . . . . . 309

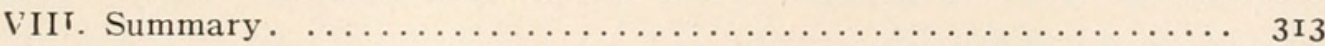

\section{INTRODUCTION.}

It is a familiar fact that within certain limits within which the organism can continue to function normally, metabolic ra:e varies directly with temperature. As far back as 1865 , Sachs (1865) studied the effect of rise in temperature upon a great number of biological phenomena and with a great variety of material, and came to that general conclusion. Very accurate data upon the rate of growth were obtained by Féré (1894) working with hen's eggs; upon rate of activity of protoplasm by Nägeli (I860), Schultze (I863), Hofmeister (I867), and others, and especially by Velten (1876) who made an accurate quantitative determination of the effect of temperature upon the activity of chlorophyll grains in Elodea, Vallisneria and Chara; upon oxygen absorption, by Treviranus (I83I) working on the honeybee; upon carbon dioxide excretion, by Rossbach (1872) in studies on the contraction rate of vacuoles in various protozoa; and 
upon these and other phases of the subject by many other later investigators. The general conclusions on the direct effect of temperature may be summed up in the words of Verworn (I899): "Within certain limits increasing temperature acts to augment vital processes. Up to a certain point excitation increases with increase of temperature. This holds good for very different phenomena and for very different forms of living substance."

But the phenomenon of acclimation to temperature changes, while well known, has not been submitted to extensive analysis. It has been observed of course that in warm springs organisms are found, living at temperatures as high as $85^{\circ} \mathrm{C}$. (Flourens, I846), or even $98^{\circ} \mathrm{C}$. (Ehrenberg, I 859), closely related to species which live in water seldom as high as $40^{\circ} \mathrm{C}$. Acclimation to temperature has also been observed in Euglena, where Schwartz (I884) and Aderhold (I888), working separately, found that Euglena collected in summer are not active below $5^{\circ}$ or $6^{\circ} \mathrm{C}$., in winter at as low as $0^{\circ} \mathrm{C}$. No explanation for this phenomenon is offered and no further experiments have been performed upon this material. But Dallinger (I880) found that flagellates will endure a rise of temperature from $15.6^{\circ} \mathrm{C}$. to $70^{\circ} \mathrm{C}$. if the change is very gradual. And both Schottelius (1867) and Dieudonné (I894) succeeded in causing bacilli which normally produced a fluorescing pigment and trimethylamine at $22^{\circ}$ and not at $35^{\circ}$, to produce these substances at $35^{\circ}$ if kept at that temperature through a sufficient number of generations.

The most complete and elaborate experiments on vertebrates are those of Davenport and Castle (I895) upon Bufo tadpoles, and those of Loeb and Wasteneys (I9I2) upon Fundulus. Davenport and Castle found that Bufo tadpoles kept at $15^{\circ}$ went into heat rigor at $40.3^{\circ} \mathrm{C}$., from which state recovery was possible; but those kept at $25^{\circ} \mathrm{C}$. for 28 days resisted this higher temperature perfectly, going into heat rigor only at $43.5^{\circ}$. If brought back to $I 5^{\circ}$ for $\mathrm{I} 7$ days they lost their resistance to high temperature, but only partially, going into heat rigor now at $4 \mathrm{I} .6^{\circ} \mathrm{C}$. The Fundulus experiments of Loeb and Wasteneys showed similar results. Fish from a temperature of $10^{\circ} \mathrm{C}$. die in less than two hours at $29^{\circ} \mathrm{C}$., and in a few minutes at $35^{\circ} \mathrm{C}$.; but if first exposed to $27^{\circ} \mathrm{C}$. for 40 hours they can live indefinitely at $35^{\circ} \mathrm{C}$., and 
may even endure $39^{\circ}$ if the rise is gradual. This acquired resistance to high temperature persists through four weeks' subsequent exposure to very low temperature. In these two cases an alteration of temperature has evidently produced a persistent effect on the protoplasm.

All the observations and experiments quoted show that organisms have the capacity to acclimate to considerable changes of temperature if these are brought about gradually; but very slight attempts have been made to give an explanation of the physiological significance of the acclimation process. The only noteworthy attempt to analyze the processes involved in acclimation is that of Davenport (I897). In regard to the Confervæ that live in hot springs, he suggests the following: Since it is known that the coagulation point of at least one protein, egg albumin, rises in proportion as it is dried, and since a number of investigators have held that death from high temperature is due to coagulation of proteins, the increased resistance to extreme heat is probably due to loss of water. However, there is some evidence at present that death from high temperature is due rather to accumulation of acids in the tissues (Mayer, 'I 7 ), which throws some doubt upon Davenport's interpretation of acclimation in hot springs. Further, acclimation to extreme cold is, according to Davenport, a loss of irritability. The process of acclimation, then, consists in the modification of protoplasm through excessive heat or cold in such a way that it is not so strongly irritated by these extreme temperatures, and that the coagulation and freezing points are shifted, possibly through loss of water ( 1897, p. 258). This conception of the process of acclimation is inadequate in that it regards protoplasm as a static mass, which alters its condition through successive stages, rather than as a continually changing dynamic system.

The studies reported in this paper were undertaken to determine the effect of temperature changes upon the metabolism of Planaria dorotocephala and to discover if possible a physiological basis for the phenomenon of acclimation to temperature changes.

The work was carried on at the University of Chicago, I9I 5I9I 8, at the suggestion and under the direction of Prof. C. M. 
Child. It is a great pleasure to me to have this opportunity to express my thanks to Professor Child, not only for the stimulus of his ideas and for his valuable suggestions, but for his kindness in placing at my disposal certain unpublished data from his own experiments concerning the effect of temperature on head-frequency and head-form in the regeneration of pieces of Planaria. My warm thanks are due to Dr. L. H. Hyman, of the Department of Zoölogy of the University of Chicago, for her keen and thoughtful criticism, constant encouragement, and constructive advice. I wish further to acknowledge my deep indebtedness to other colleagues and to the friends whose help during these three years has made effort easy.

\section{Material, General Methods and Terminology.}

The material used for these experiments was Planaria dorotocephala, one of the triclad turbellarians, the same species used extensively by Child (' $\mathrm{I}, a, b, c$, etc.) in his earlier studies on the axial metabolic gradient. It is found in the springs that feed into swamps a short distance back from the banks of the Fox River, near Cary, Ill. The material lends itself very well to temperature experiments; for though its natural habitat is in waters of relatively low temperature, the stock lives readily in the laboratory at $\mathrm{I} 7^{\circ} \mathrm{C}$., and can continue to exist to all intents normally in temperatures varying from somewhat over $30^{\circ} \mathrm{C}$. to at least as low as $4^{\circ}$. The temperatures employed all lay well within these limits, between $30^{\circ}$ and $5^{\circ}$. The stock was collected and brought into the laboratory at intervals during the time covered by the experiments, and was fed on liver three times weekly (the frequency which has been found necessary to maintain growth) throughout the period. ${ }^{1}$ With this treatment the stock maintains itself in normal condition.

For the experimental work three general temperatures were employed, approximately $10^{\circ}$ apart; that of the refrigerator ranging between about $8^{\circ}$ and $10^{\circ} \mathrm{C}$., that of the general laboratory, $18^{\circ}$ to $20^{\circ}$; and that of a warm chamber, between $27^{\circ}$ and

1 Dr:ring a part of the tirie high temperature stock was fed mo:e often, as it was found that metabolism is so rapid at raised imperature on tri-weekly feedings that the worms not only may not grow but may even derrease in size. 
$30^{\circ}$ C. For convenience these will be called "low," "medium" and "high," and the exact temperatures given only when this seems significant for the purpose of the experiment. Several other terms used should be explained here. By "living" temperature is meant, not the temperature of the natural environment, but that temperature at which they have been living for a certain experimental period; in acclimation experiments there is an "acclimation temperature." "Regulation temperature" means that temperature to which the worms are subjected during regulation; similarly, "testing temperature" means the temperature at which the metabolic condition of the worms is tested. When two temperatures are given, the first is the living, the second the testing or regulating temperature.

The general methods employed in estimating the effect of temperature upon the metabolism were:

I. Susceptibility.

2. Measurements of $\mathrm{CO}_{2}$ production by

I. Colorimetric method.

2. The biometer.

3. Rate of regulation and head-frequency.

These methods will be described more fully as the experiments are reported.

\section{General Observations.}

Even before any actual experiments are attempted, certain general observations on the effect of temperature upon the worms can be made. Out-of-door stock lives at a temperature of not more than $8-14^{\circ}$. Under these conditions the worms are not very active, rather small but stocky, and of dark color. When brought into the laboratory and kept there under temperature conditions approximately like those out-of-doors they maintain the same general appearance and are very sluggish even in response to light. When kept at ordinary room temperature, however, which during most seasons of the year represents a rise of at least $7-8^{\circ} \mathrm{C}$., the stock becomes more active and loses some of its heavy pigmentation, changes which we have come to associate with more rapid metabolism. Even if well fed the worm shows these changes; and they are much more marked in stock that is put at still higher temperature. At $27-30^{\circ} \mathrm{C}$. 
the metabolic rate is so high that it is difficult to keep stock sufficiently nourished to allow it to increase in size. The worms are restless, and soon become thinner, narrower and much lighter in color. For example, a stock collected November 17, I9I7 and set in the warm chamber January II, I9I8 at average temperature of $27.5^{\circ}$ was fed tri-weekly. The reduction in size was rapid; the worms originally $\mathrm{I} 5^{-1} 8 \mathrm{~mm}$. in length decreased within a period of two weeks to 9-Io mm., and were very much more slender than the worms of the same stock and size in the same temperature under daily feeding. It was further noticed, though no measurements were taken, that this reduction was more rapid, even, than in a parallel starvation stock at lower temperatures-ranging from $14-16^{\circ}$. That these differences in appearance and behavior are directly associated with the metabolic rate needs no further proof. Even the pigment changes cannot be a matter of kind of food but must, it seems, be related to oxidation rate in some such way as the alterations in pigmentation which cause seasonal dimorphism in butterflies (Dorfmeister, I879, Weismann, I895, et al.).

IV. Relation of Susceptibility to Temperature Changes.

The experiments to be reported in this section deal with alterations of metabolic rate in acclimation as tested by the susceptibility method. This method as devised by Child ('I $3 a$ ) consists in subjecting the animals to concentrations of certain agents which will kill them slowly enough to permit one to observe accurately differences in their time of death. Child has sufficiently demonstrated that the time required for death is dependent upon metabolic rate, being shorter the higher the rate. Therefore in my experiments I have used the time required for death as a measure of the effect of various conditions of temperature upon the metabolic rate.

In all the experiments reported here, $\mathrm{KNC}$ was the agent used. The work of earlier physiologists, notably that of Geppert (I889), demonstrated that the action of KNC on vertebrates in some way prevents the tissues from utilizing the oxygen of the blood. Loeb and various other more recent workers have used KNC extensively to inhibit oxidations; and it has been shown 
that cyanides decrease the activity of oxidizing enzymes. Hyman ('I6) has recently shown that in all except very low concentrations cyanides decrease oxygen consumption in the sponge. I am also permitted to mention the results of recent experiments on Planaria dorotocephala not yet published: Dr. Hyman shows that here also cyanides decrease oxygen consumption to a marked degree, and Professor Child has been able to demonstrate a parallel decrease in $\mathrm{CO}_{2}$ production in the same material under the influence of cyanides. This action of $\mathrm{KNC}$ upon oxidation makes it very effective for the purposes of these experiments, since metabolic rates are best measured in terms of oxidative processes. And Child (' $13 a$ ) has presented evidence of the fact that susceptibility to cyanide increases with rise in temperature, so there is good precedent for the use of this agent.

The concentration of KNC found most effective was a I/I,Ooo molecular solution made up with water of the appropriate temperature. In each lot Io worms of as nearly as possible the same size were used. They were put in a Ioo c.c. Erlenmeyer flask, the water drained off and the worms then rinsed in the appropriate cyanide solution (made up fresh each time), after which the flasks were filled and stoppered tightly to prevent loss of KNC by evaporation. The method of recording death rates was that employed by Child ('I5) in which certain arbitrarily defined stages in the course of disintegration were distinguished as follows:

Stage I.-The worm is still intact.

Stage II.-The first signs of disintegration are apparent. These usually appear at the head end but, as we would expect, also very soon in the region of the posterior zooids.

Stage III.-The beginning of disintegration on the margins posterior to the head.

Stage IV.-Margins completely disintegrated.

Stage V.-There is no tissue left with any appearance of life.

From the data thus obtained graphs were plotted by the method that Child has previsouly used ('I5, p. 8I). ${ }^{1}$

1 This methori consists in giving numerical values to the stages of disintegration as follows: Stage II., I; Stage III., 2; Stage IV., 3; Stage V., 4; and using as 


\section{A. Long Time Acclimations.}

In the first series of experiments, stocks of worms were used which had been in the three temperatures for periods of time from three days to three months. The susceptibility of lots of worms from each of these stocks was then tested at a different

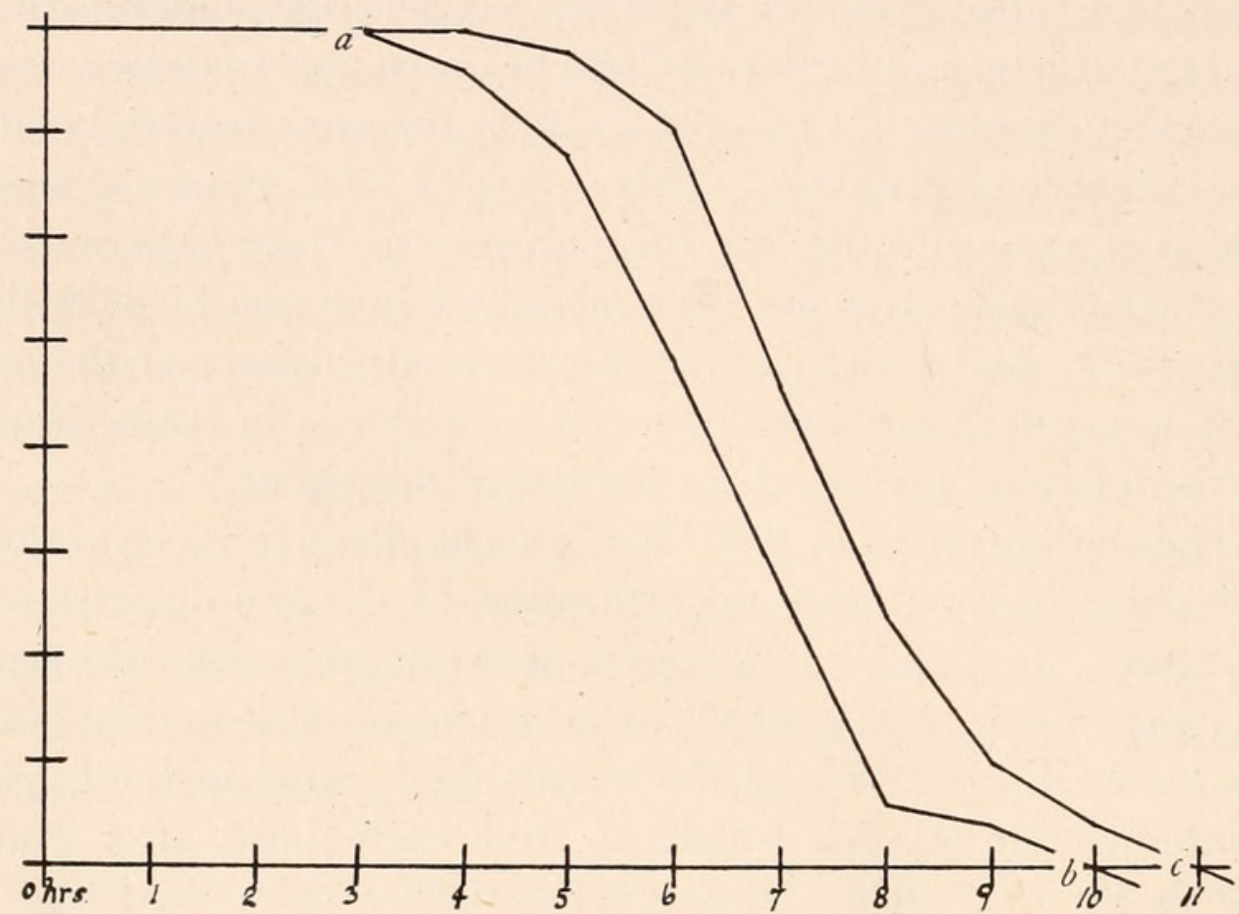

FIG. I:

temperature and compared with that of worms which had been living at that temperature. All possible combinations of temperatures were used. The graphs represented by Figs. I and 2, from worms with one week "acclimation," with temperature ordinates these values multiplied by the number of worms in each stage at each time interval, with the time intervals as abscissæ.

Since ten worms were used in each series, the highest possible numerical total, i. $e$., the largest ordinate, will be 40 , and will be attained when all the worms have reached Stage V., i. e., are dead and disintegrated. The axis of ordinates is therefore divided into 40 spaces, each representing one unit of numerical value, and since the progress of death is most easily represented by descending curves, the ordinates are measured from above downward. Thus, for example, if we have a lot of ten worms which at a given time show the following groupings as regards stages of disintegration:

Stage I. Stage II. Stage III. Stage IV. Stage V

2 worms 2 worms 4 worms 2 worms

The sum of the numerical values will be $2+4+\mathrm{I} 2+8=26$, which is the ordinate for the curve at this time, and is to be measured downward from the zero point (see Fig. I). 
changes in both directions, are typical of the results of such experiments. Fig. I shows the susceptibility of two lots of worms, the experimental lot (medium-high) from a medium living temperature, represented by the curve $a-b$; the control (highhigh) from a high living temperature, represented by the curve $a-c$; the susceptibility of both was tested at high. The position of the curve $a-b$ well to the left of the curve $a-c$ indicates that the worms which have been put suddenly from medium into high temperature to test are more susceptible to cyanide than the worms which have been living at that high temperature for a week previous to testing. Fig. 2 shows the same kind of experi-

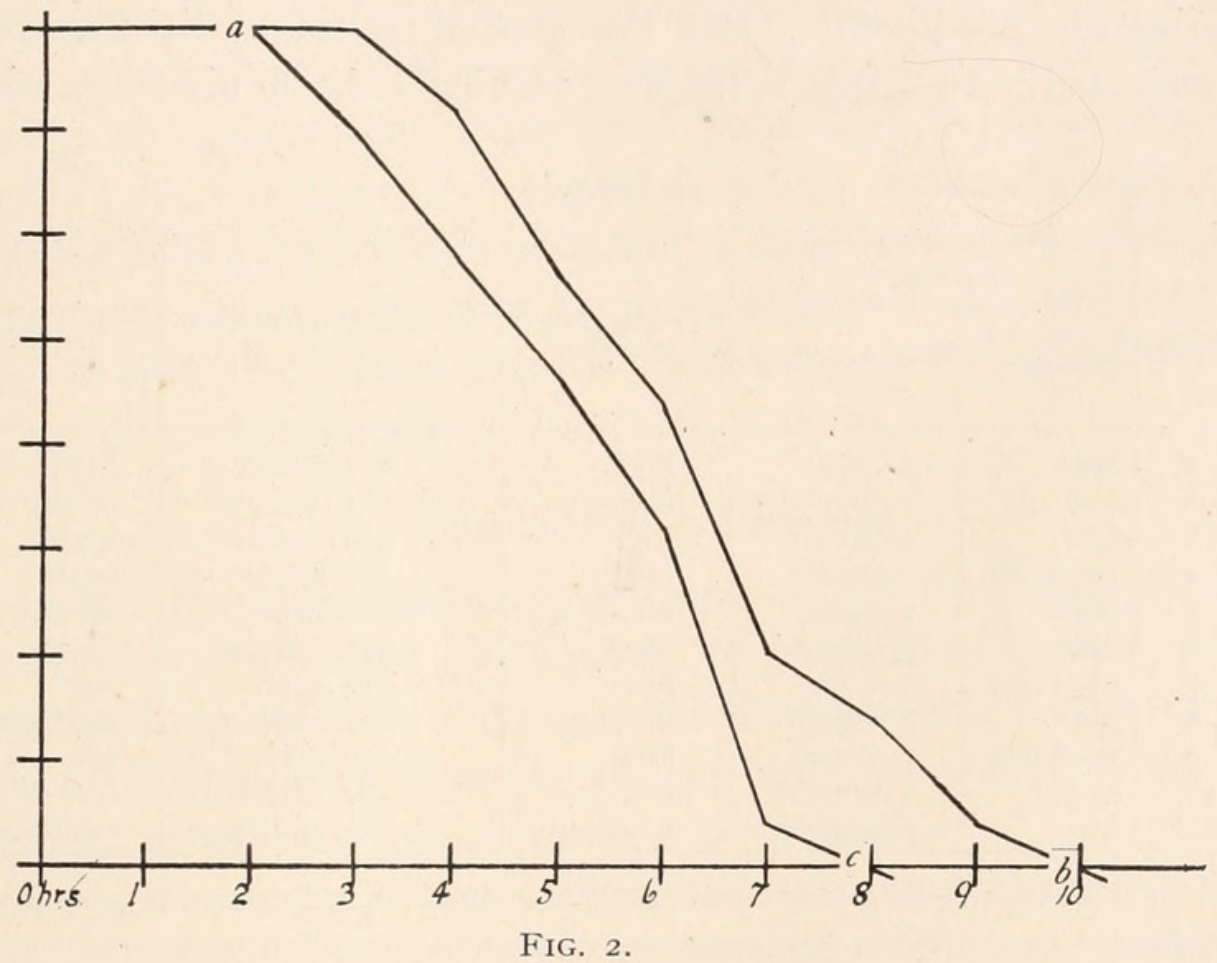

ment with opposite temperature change; here the experimental lot was living at high temperature a week, and its susceptibility, tested at medium temperature, compared with that of a control which had been living at that medium temperature. The curve $a-b$ here represents the experimental (high-medium) lot, the curve $a-c$ the control (medium-medium). The fact that the curve $a-b$ lies well to the right of the curve $a-c$ shows plainly that the worms which have been put into medium temperature to test are less susceptible to cyanide if they have previously been living at high for a week than if they have been in the medium temperature during that length of time. 
It appears from the two graphs, then, that worms whose susceptibility is tested at a higher temperature than that at which they were living for a week are more susceptible than the controls; worms tested at a lower temperature than that at which they had lived a week previously are less susceptible than the controls.

Other data supporting these general conclusions are given below in Table I. Here are given the results of typical experiments differing from those pictured in Figs. I and 2 merely in the length of time that the experimental worms had lived in one temperature before being tested at the other. Some experiments with each direction of temperature change from the living to the testing one are given. Only the time of complete disintegration is recorded. In Table I. the first vertical column gives the series

TABLE I.

\begin{tabular}{|c|c|c|c|c|c|}
\hline \multirow[b]{2}{*}{ Series. } & \multicolumn{2}{|c|}{ Experiment. } & \multirow[b]{2}{*}{$\begin{array}{l}\text { Testing Tem- } \\
\text { perature. }\end{array}$} & \multirow[b]{2}{*}{$\begin{array}{c}\text { Experimental Worms } \\
\text { Died. }\end{array}$} & \multirow[b]{2}{*}{ Controls. } \\
\hline & $\begin{array}{l}\text { Acclimation } \\
\text { Tempera- } \\
\text { ture. }\end{array}$ & $\begin{array}{l}\text { Period of Accli- } \\
\text { mation. }\end{array}$ & & & \\
\hline $\begin{array}{l}\text { I } \\
2 \\
3 \\
4 \\
5 \\
6 \\
7 \\
8 \\
9 \\
\text { IO } \\
\text { I I }\end{array}$ & $\begin{array}{l}\text { low } \\
\text { low } \\
\text { low } \\
\text { medium } \\
\text { high } \\
\text { low- } \\
\text { medium } \\
\text { low- } \\
\text { medium } \\
\text { high } \\
\text { low- }\end{array}$ & $\begin{array}{l}3 \text { days } \\
4 \text { days } \\
4 \text { days } \\
\text { I week } \\
\text { I week } \\
3 \text { weeks } \\
3 \text { weeks } \\
\text { I month } \\
\text { I month } \\
2 \text { months } \\
3 \text { months }\end{array}$ & $\begin{array}{l}\text { high } \\
\text { medium } \\
\text { high } \\
\text { high } \\
\text { medium } \\
\text { high } \\
\text { low } \\
\text { medium } \\
\text { low } \\
\text { low } \\
\text { medium }\end{array}$ & $\begin{array}{l}\text { I hr. before } \\
3 \text { hrs. before } \\
3 \text { hrs. before } \\
\text { I hr. before } \\
6 \text { hrs. after } \\
2 \text { hrs. before } \\
2 \text { hrs. after } \\
2 \text { hrs. before } \\
2 \text { hrs. after } \\
\text { Io hrs. after } \\
2 \text { hrs. + before }\end{array}$ & $\begin{array}{l}\text { high } \\
\text { medium } \\
\text { high } \\
\text { high } \\
\text { medium } \\
\text { high } \\
\text { low } \\
\text { medium } \\
\text { low } \\
\text { low } \\
\text { medium }\end{array}$ \\
\hline
\end{tabular}

* In this case the difference between experimental lot and control is greater than is indicated in the table, because observation was concluded before the controls were completely dead and disintegrated.

numbers; the second column headed "acclimation temperature" gives the temperature the effect of which on a second change of temperature is to be tested. The third column, "acclimaţion period," gives the length of time during which the animals are kept at acclimation temperature. The fourth column, "testing temperature," gives the temperature at which the animals were tested. The fifth column shows whether the experimental lot is more or less susceptible than the control. And the last column shows the temperature at which the control worms were living 
and are tested. For example, in No. I, the experimental worms were kept three days in low temperature; then their susceptibility to KNC was tested at high temperature; and it was found that in general they died an hour earlier than the controls which had been living and were tested at high.

These eleven experiments give results similar to those indicated in the preceding graphs; worms tested immediately after they have been put into a higher temperature than that at which they have been living for a shorter or longer time show greater susceptibility to cyanide than those which have been living indefinitely at the higher temperature; those tested immediately after they have been put into a lower temperature than that at which they have been living for a shorter or longer time show a lower susceptibility to cyanide than those which have been living indefinitely at the lower temperature. In other words, worms brought into a given temperature after a period of exposure to another temperature show a difference in metabolic rate as indicated by susceptibility from the animals which have been living indefinitely at the given temperature.

\section{B. Short Time Acclimation.}

In the preceding section it has been shown that susceptibility to cyanide is modified by exposure to given temperatures for as short a time as three days. Further experiments were undertaken to determine whether or not such modification can be brought about in a still shorter period of time.

A few experiments were performed with worms which had lived but 36 hours at a particular temperature. These experiments presented nothing new and were therefore soon discontinued. Fig. 3 illustrates the general results of such experiments as were made. It is the record of Io worms acclimated to $30^{\circ}$ for 36 hours (curve $a-c$ ), compared in $\mathrm{KNC}$ at $16^{\circ}$ with worms which had been living at $16^{\circ}$ (curve $a-b$ ). This graph shows that worms living at high temperature for 36 hours are less susceptible to cyanide in low temperature than worms which have been living at that low temperature; that is, that even so short a period as 36 hours is long enough to modify the metabolic rate, though not to so marked a degree as longer time intervals. 
A large number of experiments were performed to determine whether a I2 hours' exposure to a given temperature would alter

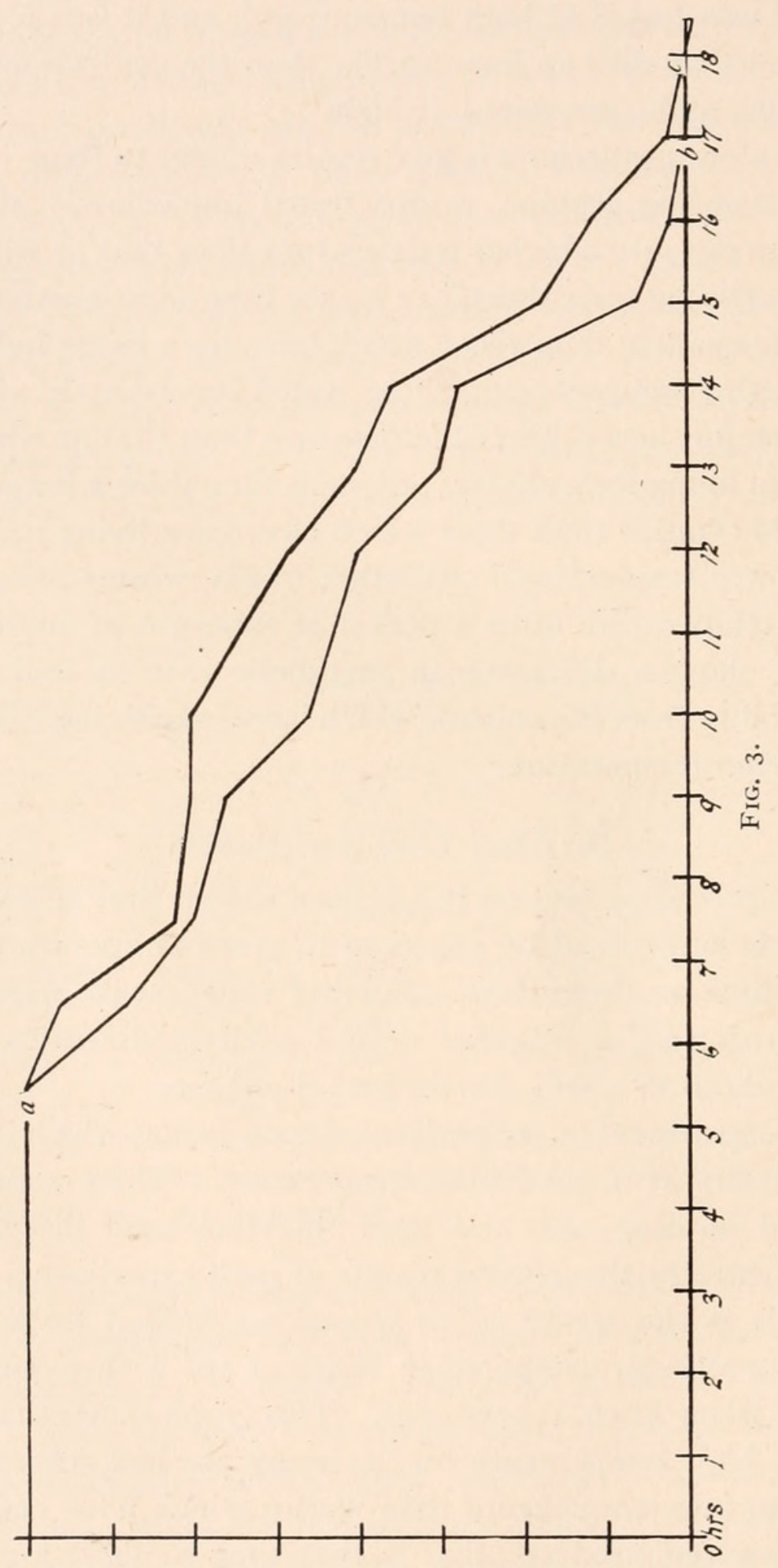

the susceptibility to cyanide. Worms from stocks kept for various lengths of time at one temperature were placed for 
twelve hours in a different temperature; the susceptibility to cyanide was then compared at the second temperature with that of worms from the same stock which had not been exposed to the second temperature until the time of testing. Both lots were tested at the second temperature. If the worms show consistently different death rates it will be proof that time intervals as short as these few hours actually produce persistent modifications in metabolism. The results are more easily tabulated and considered in separate groups according to the direction of the temperature change.

In Table II. the experimental lots are brought into a tempera-

TABLE II.

Lowered Temperature.

Comparative Susceptibility.

\begin{tabular}{|c|c|c|c|c|}
\hline No. & Control Lots. & & Experir & mental Lots. \\
\hline I & high-low & $>$ & high, & I 2 hrs. low \\
\hline 2 & “ & $>$ & “" & I 2 hrs. “" \\
\hline 3 & “ & $<$ & “ & I 2 hrs. "“ \\
\hline 4 & “" & $=$ & " & I 2 hrs. "“ \\
\hline 5 & $\because$ & $<$ & ‘ & I 2 hrs. "“ \\
\hline 6 & “ & $<$ & “. & I 2 hrs. “" \\
\hline 7 & “ & $<$ & “ & I 2 hrs. “” \\
\hline 8 & ““ & $<$ & ““ & I 2 hrs. "“ \\
\hline 9 & “ & $<$ & “ & I 2 hrs. " \\
\hline Io & ““ & $>$ & “. & I 2 hrs. " \\
\hline I I & “" & $<$ & “ & I 2 hrs. "“ \\
\hline I 2 & high-medium & $<$ & “ & I 2 hrs. medium \\
\hline I3 & “ & $=$ & “ & I 2 hrs. \\
\hline I4 & “ & $>$ & “ & I 2 hrs. \\
\hline I 5 & “" & $<$ & “ & I 2 hrs. \\
\hline I6 & medium-low & $<$ & medium, & I 2 hrs. low \\
\hline I 7 & “ & $<$ & “ & I 2 hrs. " \\
\hline I 8 & “" & $<$ & “" & I2 hrs. " " \\
\hline I9 & “ & $<$ & ““ & I 2 hrs. “ \\
\hline 20 & “" & $<$ & “" & I 2 hrs. “" \\
\hline $2 \mathrm{I}$ & “" & $<$ & “ & I 2 hrs. " \\
\hline 22 & “، & $<$ & “" & I 2 hrs. " \\
\hline
\end{tabular}

ture below that at which they have been living and remain there I2 hours before determination of their susceptibility is begun. The control lots, on the other hand, are brought into the lower temperature only when the determination of susceptibility begins. The table shows the difference in susceptibility between such 
pairs of lots. In no. I for example, the control lot brought from high to low temperature at the time of susceptibility determination shows a susceptibility greater than that of the experimental lot which has been 12 hours at the low temperature before the susceptibility determination.

Of these twenty-two cases almost 73 per cent. show that I2 hours in a lower temperature than the living one before the addition of cyanide makes the worms more susceptible to cyanide than those which have been subjected to the depressing influence of the cold and of the cyanide simultaneously; in other words, the worms first brought into low temperature then subjected to cyanide die faster than those brought into low temperature and cyanide at the same time. Judging from these data a I2 hours' subjection to a lower temperature produces some degree of adjustment; in most cases the worms have apparently undergone some increase in metabolic rate during the twelve hours at the lower temperature. Just what the nature of this adjustment is had better be considered later when there are more data from which to judge. But that it is not merely a shock effect is evident from a comparison of the effects of acclimation periods of various lengths. In I 2 hours the worms show less acclimation than in 36 hours, and in that period less than in three days, so that evidently the process is not ended in a period shorter than three days, which itself is surely too long a time for shock effect from a change of $10^{\circ}$ to persist. The process then is gradual, covering a considerable period of time, which may range from three days to one week, by which time the acclimation is fairly complete and the new rate established.

The possible sources of error in these experiments account for most of the exceptional results quite readily. The series tested at low temperature all take so long even to begin disintegration that some degree of acclimation undoubtedly occurs in the period before death begins, which would bring the two lots very nearly to the same rate. This might well explain the inconsistency in no. I4, where a relation like the majority held until the last half hour at which time the condition became reversed. The fact that the series were not followed up to complete disintegration may explain the result of nos. 4 and I3. The worms 
of nos. I and 2 belonged to a series which had previously been shifted several times from one temperature to another for very short periods of time; the repeated changes may have been so frequent as to check the effect of the last change. The result of the last of these six exceptions (a little over 27 per cent. of the total number of experiments), no. Io, can only be explained on the ground of possible individual variation.

Twenty-three experiments with temperature changes in the opposite direction were performed. Table III. summarizes the

TABLE III.

Raised Temperature.

Comparative Susceptibility.

\begin{tabular}{|c|c|c|c|c|c|c|}
\hline No. & \multirow{2}{*}{\multicolumn{2}{|c|}{$\begin{array}{l}\text { Control Lots. } \\
\text { low-high }\end{array}$}} & \multicolumn{4}{|c|}{ Experimental Lots. } \\
\hline I & & & $>$ & low, & I $2 \mathrm{hrs}$. & high \\
\hline 2 & “. & “ & $>$ & “ & I 2 hrs. & “ \\
\hline 3 & “ & “ & $=$ & “ & I 2 hrs. & “ \\
\hline 4 & “" & “ & $<$ & “" & I $2 \mathrm{hrs}$. & “ \\
\hline 5 & “ & “ & $=$ & “ & I 2 hrs. & “ \\
\hline 6 & ““ & “ & $>$ & “ & I $2 \mathrm{hrs}$. & ““ \\
\hline 7 & ““ & “ & $=$ & “" & I 2 hrs. & “" \\
\hline 8 & “ & “. & $=$ & “. & I 2 hrs. & “ \\
\hline 9 & “ & “ & $>$ & “ & I $2 \mathrm{hrs}$. & “. \\
\hline 10 & “ & “ & $>$ & “ & I 2 hrs. & “ \\
\hline I I & low-n & dium & $>$ & “ & I 2 hrs. & medium \\
\hline I 2 & “ & “ & $=$ & “ & I $2 \mathrm{hrs}$. & “ \\
\hline I3 & “ & “" & $<$ & “ & I 2 hrs. & “ \\
\hline I 4 & “" & “ & $>$ & “ & I 2 hrs. & “ \\
\hline I 5 & “" & “" & $=$ & “ & I 2 hrs. & “" \\
\hline I6 & “" & “" & $>$ & “ & I 2 hrs. & “ \\
\hline 17 & “ & “" & $>$ & “ & I $2 \mathrm{hrs}$. & “ \\
\hline I8 & mediu & -high & $<$ & medium, & I 2 hrs. & high \\
\hline I9 & “ & " & $<$ & “ & I $2 \mathrm{hrs}$. & “ \\
\hline 20 & “ & “" & $<$ & “، & I $2 \mathrm{hrs}$. & “ \\
\hline $2 \mathrm{I}$ & “ & ". & $>$ & “ & I 2 hrs. & “ \\
\hline 2 & “" & “" & $>$ & “" & I 2 hrs. & “ \\
\hline 23 & “" & “ & $>$ & “" & I 2 hrs. & “ \\
\hline
\end{tabular}

results of such experiments. In these series the experimental lots are brought into a temperature higher than that at which they have been living and remain there I 2 hours before determination of susceptibility is begun. The controls, as in Table II. above, are brought into the second temperature (in this case the higher one) only at the time when the determination of suscepti- 
bility begins. The table shows the difference in susceptibility between the two lots. Thus no. I, for example, shows that the susceptibility of a lot ("control") brought from low to high temperature only when the susceptibility determination is begun is greater than that of a lot ("experimental") which has been I2 hours at the high temperature before the susceptibility determination.

We can see from a glance at Table III. that there is much greater variability in the results in the raised temperature series than in the series with lowered temperature. Predicting results on the basis of the previous set of experiments, we would assume that after I 2 hours in a higher temperature than the living one, before subjection to the $\mathrm{KNC}$, the worms would be somewhat less susceptible than similar worms subjected to the new temperature and cyanide simultaneously. In other words, they should have become acclimated to some extent to this second change. Of the 23 series tested to determine this point ten gave the predicted result, six the opposite and seven showed no difference between the experimental and the control animals. Let us examine these to see whether a reasonable explanation for these very variable results can be found. One fact which may throw light on this question is the following: From examination of the graphs, which are not given here for lack of space, it is very evident that of the ten series which gave the result which we predicted from the findings in Table II., one showed a time interval of five hours between the death of the two series, one four hours' difference in time, and four two hours or very little less. The time intervals between complete disintegration of the two lots which showed the opposite type of result (those in which I 2 hours' acclimation did not decrease susceptibility) were mostly shorter; the curves were closer together as a rule. Apparently, then, acclimation to raised temperatures is less rapid than acclimation to lowered ones since susceptibility seems to be much less altered by 12 hours at a temperature higher than that at which the worms have been living than it is by 12 hours at a temperature lower than that at which they have been living. In the case of the highest temperature used, this apparent retardation in the process of acclimation may perhaps be ex- 
plained on the ground that this high temperature is close to the limit at which these animals can live at all after a sudden change; it has been found that they cannot live in a temperature above $30^{\circ}$ unless the temperature is raised very gradually.

The susceptibility method shows then that exposure to a given temperature for even so short a time as $\mathrm{I} 2$ hours produces a change in physiological condition (Tables II., III.). When such a I2-hour period of exposure to a given temperature is followed by exposure to a higher temperature, the susceptibility determined at the higher temperature is higher than that of animals which have been living indefinitely at this higher temperature. The susceptibility determined at a temperature lower than that of the I2 hours' period is lower than the susceptibility of worms which have been living indefinitely at that lower temperature. With increase in the period of exposure to a given temperature this effect shows in general an increase (Table I.).

\section{Carbon Dioxide Production.}

The second method used for demonstrating the differences in metabolic rate at different temperatures consisted in a comparison of the $\mathrm{CO}_{2}$ output of different lots. The measurement of $\mathrm{CO}_{2}$ has long been used by physiologists as one of the best methods available for estimating the change in metabolic rate under experimental conditions. In these experiments carbon dioxide output was measured in two ways: by the colorimeter method and by the biometer.

\section{A. The Colorimetric Method.}

The colorimetric method was an adaptation of that used extensively by Haas in the laboratory of Plant Physiology of Harvard University. It consisted essentially in measuring the comparative $\mathrm{CO}_{2}$ output of two lots of worms in terms of the color change in an indicator solution in which the worms were tested. The following indicators were tried:

$\begin{array}{lll}\text { Alizarin } & \text { Congo red } & \text { Phenolpthalein } \\ \text { Methyl orange } & \text { Benzo-purpurin } & \text { Phenolsulphone-pthalein } \\ \text { Neutral red } & \text { Liquid litmus } & \end{array}$

Of these the turning point of the first three proved to be neither sufficiently close to the $\mathrm{PH}$ of the well water, nor sharply dif- 
ferentiated enough, for the purpose of these experiments. Congo red and benzo-purpurin were not very satisfactory because they were taken up by the slime secreted by the worms so that the color in the solution itself became so varyingly diluted as to make accurate comparison uncertain. Liquid litmus and phenolpthalein were used to some extent; but by far the most satisfactory for the purposes of these experiments was the phenolsulphonepthalein used by Haas (I9I6) which combined all of the desirable qualities for a good indicator-non-toxicity, slowness of the penetration rate, great sensitiveness to very slight increase in $\mathrm{H}$-ion concentration, and a suitable working rangefrom $\mathrm{PH} 8.6$ to $\mathrm{PH}$ 6. The starting point for these experiments was of course the $\mathrm{PH}$ of the well water in which the worms lived in the laboratory-about PH 7.6; but this point is not very significant for the purposes of these experiments as no attempt was made to determine the absolute $\mathrm{PH}$ but rather the comparative changes in $\mathrm{PH}$ in terms of color differences.

In the earlier experiments equal numbers of worms of the same size were compared without weighing. Later, beginning with series XXV., and throughout the rest of the experiments, the worms were weighed and the weights recorded; and an attempt was made to put the excess weight now on one side, now on the other, so as to prevent the weight from being by any possibility the determining factor in the results. The worms were weighed in water at the temperature at which they had been living in each particular case. A small glass container with the water was first quickly balanced, and the worms were placed in this after a moment on filter paper to remove excess water. After weighing they were placed in pyrex tubes of standard volume; these were rinsed and then filled with indicator solution and sealed, with air excluded by paraffined corks, or, better paraffin plugs. The worms were then put into the new temperature away from the direct sunlight and all other strong illumination in order to preclude the possibility of stimulation from those sources. To avoid as far as possible the differences in motor activity resulting from differences in temperature the worms were decapitated, (except in a few cases indicated in the table), shortly before weighing. At any time from ten minutes 
to twenty-four hours after decapitation there is almost complete inactivity in all the different temperatures, and the time between decapitation and experiment was always within these limits. That the animals do not excrete any appreciable amount of any non-volatile acid was shown by the fact that after the color change was produced by the worms the indicator solution could be brought back to the original color by shaking thoroughly with air; and there is no good reason to believe that they excrete any other volatile acid than $\mathrm{CO}_{2}$.

The results obtained by this method are briefly as follows: first, worms brought from a low to a higher temperature show in the higher temperature a higher rate of metabolism as indicated by $\mathrm{CO}_{2}$ production than that of the worms which have lived at the higher temperature; second, so far as the evidence goes worms brought from a higher to a lower temperature show a lower rate of $\mathrm{CO}_{2}$ production than those which have been living at the lower temperature. Table IV. gives the results of 24 experiments in which worms acclimated to low and tested at medium temperature (experimental) are compared with worms which have been living indefinitely and are tested at medium temperature (control).

As can be seen at a glance the majority of these experiments gave very consistent results, extensive and beautiful evidence that worms acclimated to cold showed higher $\mathrm{CO}_{2}$ production in medium temperature than worms acclimated to and tested at the medium temperature. Of the twenty-four experiments performed, seventeen, that is, 83 per cent., gave this result. The possibilities of experimental error here are: Observations over too short a period of time; too great a discrepancy in the weights of the two lots of worms; the inaccuracy of judgment due to the use of an unsatisfactory indicator. Of the four exceptions to the majority rule in this table, three, nos. 2, 6 and $2 \mathrm{I}$, can all be explained on one or the other of these grounds. No. 5 is explicable only as the result of individual variations in rate of $\mathrm{CO}_{2}$ production, which are sometimes considerable.

The other two possible "raised-temperature" series-mediumhigh and low-high-gave results in the main like that of Table IV.; worms acclimated to a lower temperature than the one at 
TABLE IV.

\begin{tabular}{|c|c|c|c|c|c|c|}
\hline \multirow{4}{*}{$\begin{array}{c}\text { No. } \\
\text { I }\end{array}$} & \multirow{3}{*}{$\begin{array}{l}\text { Time Between Beginning } \\
\text { of Experiment and } \\
\text { First Noticeable Color } \\
\text { Difference. } \\
\text { I hr. }\end{array}$} & \multicolumn{5}{|c|}{$\mathrm{CO}_{2}$ Production. } \\
\hline & & Control & ots. & & Experit & ntal Lots \\
\hline & & medium-1 & edium & $>$ & low- & edium \\
\hline & $21 / 2 \mathrm{hrs}$. & “ & “" & $<$ & “ & “" \\
\hline 2 & 5 hrs. & “ & “ & $>$ & “ & “، \\
\hline 3 & 2 hrs. & “ & “” & $=$ & “ & “ \\
\hline & 4 hrs. & “ & “" & $<$ & “ & “ \\
\hline 4 & I $1 / 2 \mathrm{hrs}$. & “ & “ & $<$ & “ & “ \\
\hline 5 & $21 / 2 \mathrm{hrs}$. & “" & “ & $=$ & “ & “" \\
\hline & $31 / 4 \mathrm{hrs}$. & “ & “ & $>$ & “. & “ \\
\hline 6 & $1 / 2 \mathrm{hr}$. & “ & “. & $>$ & “. & “. \\
\hline 7 & $1 / 2 \mathrm{hr}$. & “" & “ & $>$ & “ & “ \\
\hline & $6 \mathrm{hrs}$. & “ & “" & $<$ & “ & “ \\
\hline 8 & $1 / 2 \mathrm{hr}$. & “ & “ & $>$ & “ & ، \\
\hline & I hr. & “. & “. & $<$ & “ & “" \\
\hline 9 & I hr. & “. & “. & $<$ & “ & “ \\
\hline Io (heads present) & $1 / 2 \mathrm{hr}$. & “ & “" & $<$ & “. & “. \\
\hline II & $1 / 2 \mathrm{hr}$. & “. & “ & $<$ & “، & “ \\
\hline I 2 & 3 hrs. & “. & “ & $<$ & “، & “ \\
\hline I3 (heads present) & $1 / 2 \mathrm{hr}$. & “. & . & $<$ & “. & “، \\
\hline I 4 & $1 / 2 \mathrm{hr}$. & “. & “. & $>$ & “ & “. \\
\hline & $\mathrm{I} 1 / 2 \mathrm{hrs}$. & “. & “. & $=$ & ، & “. \\
\hline & 3 hrs. & “ & “، & $<$ & “ & ، \\
\hline I5 (heads present) & $31 / 2 \mathrm{hrs}$. & “. & “. & $<$ & “، & ، \\
\hline I6 & $31 / 2 \mathrm{hrs}$. & “. & ، & $<$ & ، & ." \\
\hline I 7 & $1 / 2 \mathrm{hr}$. & “. & “. & $<$ & “ & “. \\
\hline 18 & $1 / 2 \mathrm{hr}$. & “. & “. & $<$ & “ & “. \\
\hline I9 (heads present) & $\mathrm{I} 1 / 2 \mathrm{hrs}$. & “. & “، & $<$ & “. & “. \\
\hline 20 & $\mathrm{I} 1 / 2 \mathrm{hrs}$. & “. & “، & $<$ & “. & “. \\
\hline $2 \mathrm{I}$ & I hr. & “. & “ & $<$ & “. & ، \\
\hline & 2 hrs. & “. & “ & $>$ & “ & “. \\
\hline 22 & $3 \mathrm{hrs}$. & “ & “. & $<$ & “. & “. \\
\hline 23 & $3 / 4 \mathrm{hr}$. & “ & “" & $<$ & “ & “. \\
\hline 24 & $3 / 4 \mathrm{hr}$. & “ & “. & $<$ & “. & “. \\
\hline
\end{tabular}

which they were tested produced more $\mathrm{CO}_{2}$ in the same length of time than similar worms acclimated to and tested at the higher temperature. The only exception in this group belonged to a series exceptional in character throughout-with no apparent reason for its non-conformity except individual variations in rate. As a check upon this one series three other series with the same temperature conditions were tried later. The same length of time in the living temperature was allowed, the worms were weighed very carefully and tested with the most delicate indicator; under these conditions the typical result was obtained. 
Few experiments with temperature changes in the opposite direction-acclimation temperature higher than testing temperature - were performed. The least satisfactory of these were the "high-low" vs. "low-low" series. This was because it required so long a time for the worms to show any appreciable $\mathrm{CO}_{2}$ production that a new acclimation may have occurred or at least begun to occur in that time. Series LXVI., I, "highlow" for instance, showed no color change at all even in the controls for more than 24 hours. As the previous experiments had shown even a I2-hour period to permit of some degree of acclimation, it is evident that in the above case we are dealing with something in the nature of a second acclimation. This difficulty could have been obviated by the use of greater numbers of worms; but beyond a few experiments to illustrate this point, no further attempts were made with this temperature combination. The two series "high-medium" vs. "medium-medium" and "medium-low" vs. "low-low" showed in over 60 per cent. of the cases that worms kept at a lower temperature have a higher rate of $\mathrm{CO}_{2}$ production than those which have been suddenly brought into that temperature from a higher one.

Before leaving the subject of the indicator method, a few preliminary attempts to check the short-time acclimation periods may perhaps be mentioned. Though not conclusive on account of their small number, they are at least suggestive. The experimental procedure was as follows: Three lots of worms of as nearly as possible equal weights were taken, two that had been at low temperature, a third, the control, from medium temperature. The heads from all three lots were cut off, but at such times that one of the low temperature lots stood for a number of hoursI2 to 24 -headless before the experiment was begun; immediately after decapitating, this lot was put into medium temperature, so that it had, each time, I 2 to 24 hours in which to adjust to that temperature before its rate of $\mathrm{CO}_{2}$ production began to be measured. This gave for comparison with the control, two lots of the "low-medium" series, one of which was thus tested at once at the time of change of temperature, the other only after it had been given I2-24 hours in which to begin the process of acclimation. From the previous experimental data with short- 
time acclimation we would suppose that the lot given a number of hours' start would have begun a second acclimation to the new temperature and would consequently show a new lower rate, producing less $\mathrm{CO}_{2}$ in the same length of time than the lot which was subjected to change of temperature simultaneously with the beginning of the experiment. As a matter of fact such was the case in a few experiments tried in the way described above, at any rate up to the sixth hour after setting up the experiment, and in one case for as long as twenty-four hours at least. With other combinations of temperature in the same direction, the results were consistent with the above. "Medium-high" and "low-high" lots showed slower $\mathrm{CO}_{2}$ production if given twelve hours' start at the second temperature than if the $\mathrm{CO}_{2}$ production was estimated at once upon change of temperature. Thus even these few tentative experiments give further evidence of an acclimation after only I $2-24$ hours.

\section{B. The Biometer Method.}

The findings as to carbon dioxide production by the colorimetric method are further confirmed by the results of experiments with worms in the biometer, an apparatus devised by Tashiro (I9I4) to show very minute amounts of $\mathrm{CO}_{2}$ by the formation of crystals of barium carbonate on the surface of a drop of the hydrate, and used extensively by him in the study of nerve metabolism and to some extent by him and Child (' $13 b$ ) in experiments on this same form, Planaria dorotocephala. The biometer can be used for comparative estimation of $\mathrm{CO}_{2}$ production in Planaria, but the method is so delicate that the best results are obtained with single individuals except when the worms are very small. With larger numbers the barium carbonate forms too rapidly to permit of accurate comparison,accordingly all the experiments reported here are the results of testing one worm against another. The worms to be tested were decapitated to decrease motor activity, were weighed (in all cases except the first one), then dried for a moment on filter paper and put into the biometer on small cover slips. The method of weighing was the same as that for the colorimetric $\mathrm{CO}_{2}$ determination (see above, p. 293); as often as possible the 
excess weight was put on alternate sides in duplicate experiments, and the position of experimental and control worms in the apparatus was alternated. It should be stated, of course, that only those temperature combinations could be employed in which the testing and the control temperatures were medium since that was the only temperature at which the biometer could be operated. The "low-medium" group gave the same results as the colorimetric experiments of Table IV. above, as far as tried out. But it is from the "high-medium" lot, the one furnishing the less complete records in the colorimetric estimations, that the data below are quoted, since they are characteristic both as regards the majority results and the exceptions. Table $\mathrm{V}$. is a summary of the results of these experiments. Worms which had been living at high temperature were put into the biometer at medium and their $\mathrm{CO}_{2}$ production as determined by $\mathrm{BaCO}_{3}$ precipitation was compared at that temperature with that of worms which had been living at the medium temperature indefinitely.

TABLE V.

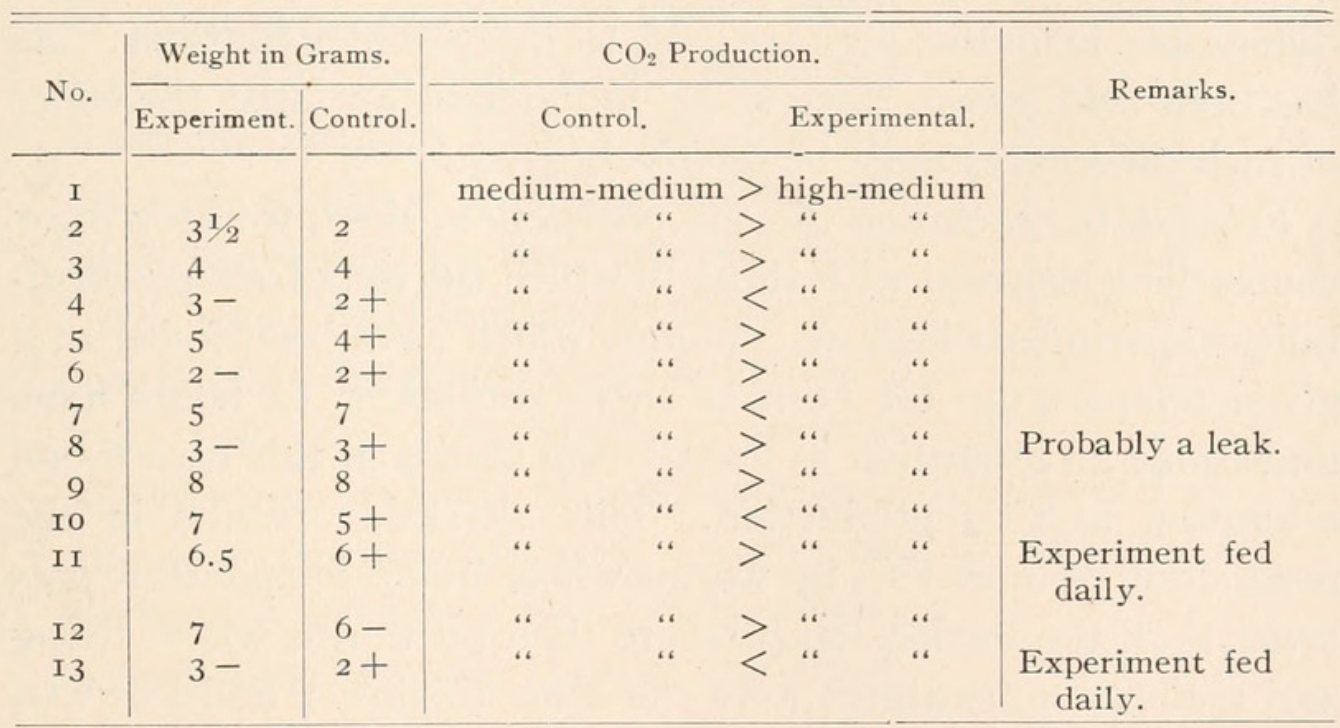

The results in the majority of the experiments harmonize with what we should expect from previous experiments. Of the I 3 experiments here, 8 , that is, nearly 62 per cent., show that animals which have been living at a higher temperature produce $\mathrm{CO}_{2}$ less rapidly, that is, they have a lower metabolic rate when tested out at a lower temperature than do animals which have 
been living at that lower temperature. Of the other four experiments, one, no. 8 (with positive results) has been left out of account, as it seemed probable that there was a leak in the biometer. In considering the exceptions we must bear in mind that small differences in weight may be enough, when dealing with such small amounts of protoplasm, to account for variations. Among the exceptions, three, nos. 4,7 and $\mathrm{I}_{3}$, have the excess weight on the experimental side, but this is not the case with the fourth, no. I2; so weight can hardly be considered the explanation. As earlier experiments had shown that it was hard to maintain high temperature stock at the usual size on tri-weekly feedings, it seemed worth while when the first few cases of nonconformity appeared, to consider whether the irregularity could be found to have a definite relation to the nutritive conditions. But after daily feeding of one stock for a month, the last three experiments, I I, I 2 and I 3 , failed to support any such theory. The excess weight was always on the experimental side yet the results differed in the different experiments, with no direct relation to the feeding. The exceptions here are probably due to slight differences in motor activity and to individual variations. As has been said above, since single individuals are used the effect of such-differences must be relatively great.

From data on carbon dioxide production, then, we may draw conclusions identical with those to which the data from susceptibility experiments lead us. Worms which have been living at a given temperature for even as short periods as I2 hours have undergone an alteration in metabolism shown in this case by an alteration in $\mathrm{CO}_{2}$ production. This alteration results in the production of more $\mathrm{CO}_{2}$ by worms whose living temperature was lower than the testing temperature than by worms whose living and testing temperatures were the same (higher); and less $\mathrm{CO}_{2}$ production by worms whose living temperature was higher than that at which they were tested than by worms whose living and testing temperatures were the same (lower) temperature.

Vi. Influence of Temperature on Head-Frequency.

A. Direct Effect of Altered Temperature.

I. During the Entire Period of Regulation.-Before taking up the question of the effect of acclimation to certain temperatures 
upon the head-frequency of regulating Planaria, we must consider: first, the significance of regulation experiments with this form; second, the factors concerned in head-frequency; and third, the direct effect of temperature on head-frequency.

In a study of regulation, whole worms are cut into certain pieces of equal size and allowed to remain for sufficient length of time to undergo growth and reorganization or redifferentiation. Planaria dorotocephala ordinarily reproduces asexually by fission, and worms above a certain size consist of two or more zooids which are distinguishable physiologically but not morphologically (Child, 'I I $c$ ). Since the head-frequency in the regulation of pieces has been found to vary according to the position of the piece with respect to the boundaries of the different zooids, it is desirable for the sake of uniformity to use pieces from a single zooid. The anterior zooid extending from the head to a short distance behind the mouth is the longest zooid, and most convenient for the purpose. Moreover, since head-frequency varies with length of piece and size of animal (Child,' I $a$, 'I $4 a$, 'I $4 b$, 'I6), pieces of uniform length from animals of approximately the same size must be used. In the experiments reported below, three pieces, representing each one third of the length of the first zooid after removal of the head, are used and are designated $A$,

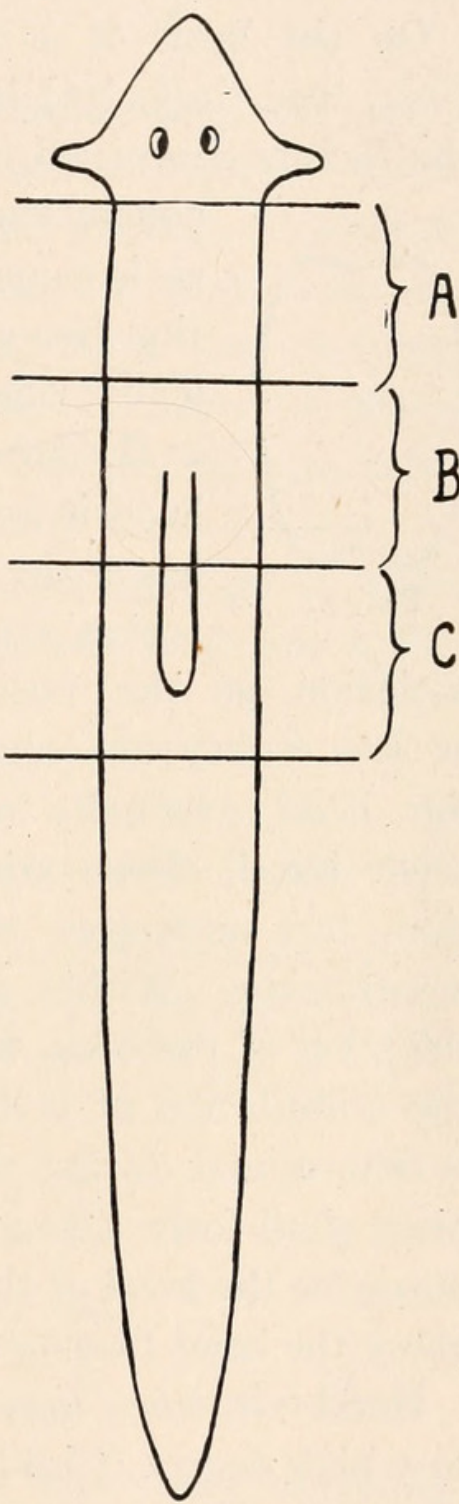

FIG. 4. $B$ and $C$, in order from anterior to posterior (see Fig. 4). In all the experiments unless otherwise stated, the temperatures used were: "low," I0-I2 $2^{\circ}$; "medium" $20^{\circ}$; "high" $29^{\circ}$. During the period of regulation the water was changed frequently to guard against the accumulation of toxic substances. Professor 
Child's morphological classification of the different degrees of cephalic differentiation between normal and headless ('I I $c$ ) is followed in all the tabulations. Worms are classified as normal; teratophthalmic, "teratomorphic, anophthalmic, and headless. In all experiments fifty pieces each were used and the numerical results are given in percentages unless otherwise stated.

On the basis of a wide range of experimental data, Child ('I3c, 'I4 $a$, 'I $4 b$, 'I6) has attempted a physiological analysis of the factors concerned in head-frequency in this species, and his

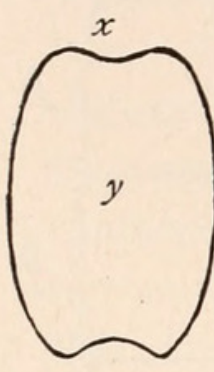

FIG. 5. conclusions are adopted in this paper. His analysis is somewhat as follows: In each piece after section two regions are to be distinguished physiologically, one which can be designated $x$, the region at the anterior end of the piece from which the new head is formed; the other designated as $y$, consisting of the remainder of the piece (see Fig. 5). The region $x$ undergoes more or less complete dedifferentiation as the result of section, its cells attain a more or less embryonic condition, and from this embryonic tissue the head gradually redifferentiates. The region $y$, on the other hand, shows stimulation through the nerves after section, but undergoes relatively little and only gradual dedifferentiation. Within any single individual, the more posterior the level of the body from which the piece is taken the greater the stimulation of $y$ (Child, 'I $4 a$ ). It has been shown that it is determined during this period of stimulation of $y$ whether a piece shall form a head or not (Child, ' $14 b$ ) and that the more posterior the level of the body from which the piece is taken the lower the head-frequency (Child, 'I I $a$, 'I 6 ).

Head-frequency may be experimentally altered and controlled to a high degree (Child, 'I I $e$, 'I6) and the results of experiments along this line together with data noted above concerning the regions $x$ and $y$ have led Child to the conclusion that a new head is formed, not through correlation with and dependence upon the rest of the piece, but so to speak in spite of it. The differentiation of a head is determined by the embryonic cells of $x$, exactly as in the embryo arising from an egg, and the region $y$ can only inhibit head development to a greater or-less degree provided its 
metabolic rate is sufficiently high in relation to that of $x$. All the experimental data agree in pointing to the conclusion that headfrequency increases with increase in rate $x$ in relation to rate $y$, and decreases with the increase of rate $y$ in relation to rate $x$. In other words, we may express head-frequency in the general formula head-frequency $=\frac{\text { rate } x}{\text { rate } y}$.

In order to show the direct effect of temperature on headfrequency, we may compare the head-frequency of pieces which have been living at a given temperature and undergo regulation at another temperature higher or lower than the first, with the head-frequency of pieces which have been living and undergo regulation at the first temperature. ${ }^{1}$ Table VI. shows the effect on head-frequency of a rise from low to medium temperature, Table VII. the effect of a fall in temperature from medium to low, and Table VIII. the effect of a rise from medium to high. In each lot, $A, B$ and $C$ consist of 50 pieces, and the headfrequencies are given in percentages.

TABLE VI.

Worms Which Have Been Living for Six Weeks at Low Temperature, Regulating at Medium.

\begin{tabular}{|c|c|c|c|c|c|c|c|c|c|}
\hline Series. & Living Temp. & Reg. Temp. & تِّ & $\begin{array}{l}\dot{\Xi} \\
\text { ż }\end{array}$ & 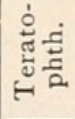 & 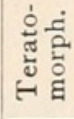 & 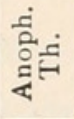 & 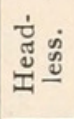 & Iึ \\
\hline $\begin{array}{c}4 \mathrm{I} 9 \mathrm{~A} . \\
\mathrm{I} .\end{array}$ & Low & Medium & $\begin{array}{l}\text { A } \\
\text { B } \\
\text { C }\end{array}$ & $\begin{array}{l}86 \\
56 \\
\text { I0 }\end{array}$ & $\begin{array}{l}\text { I } 4 \\
42 \\
62\end{array}$ & $\begin{array}{r}2 \\
14\end{array}$ & 8 & 4 & 2 \\
\hline 2. (control) & Low & Low & $\begin{array}{l}\text { A } \\
\text { B } \\
\text { C }\end{array}$ & 24 & $\begin{array}{l}76 \\
40 \\
14\end{array}$ & $\begin{array}{l}6 \\
2\end{array}$ & $\begin{array}{l}5^{2} \\
3^{\circ}\end{array}$ & $\begin{array}{r}2 \\
50\end{array}$ & 4 \\
\hline
\end{tabular}

In Table VI., for example, where the first series of pieces have been living at low and undergo regulation at medium temperature, while the second series have been living and undergo regulation at low, the rise in temperature produces a very great increase in head-frequency. In the $A$ pieces, with 24 per cent.

${ }_{1}$ These tables are made up froin unpublished records of Professor Child which he has had the great kindness to put at my disposal. Practically all my own data along this line were rendered worthless by the chlorination of the city water. 
TABLE VII.

Worms Which have Been Living for a Number of Months in the Laboratory at Medium Temperature, Regulating at Low.

\begin{tabular}{|c|c|c|c|c|c|c|c|c|c|}
\hline Series. & Living Temp. & Reg. Temp. & : & $\begin{array}{l}\dot{E} \\
\dot{0} \\
z\end{array}$ & 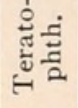 & 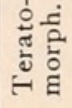 & ن & 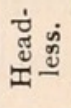 & 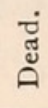 \\
\hline \multicolumn{9}{|l|}{435} & 6 \\
\hline & & & $\begin{array}{l}\text { B } \\
\text { C }\end{array}$ & 2 & $\begin{array}{r}56 \\
2\end{array}$ & $\begin{array}{l}4 \\
6\end{array}$ & $\begin{array}{l}28 \\
28\end{array}$ & $\begin{array}{l}\text { IO } \\
40\end{array}$ & 24 \\
\hline 2. (control) & Medium & Medium & $\begin{array}{l}\text { A } \\
\text { B } \\
\text { C }\end{array}$ & 78 & $\begin{array}{l}22 \\
74 \\
20\end{array}$ & $\begin{array}{l}6 \\
6\end{array}$ & $\begin{array}{l}\text { I } 8 \\
24\end{array}$ & $\begin{array}{r}2 \\
50\end{array}$ & \\
\hline
\end{tabular}

normal and 76 per cent. teratophthalmic in the control, the rise in temperature for regulation alters this head-frequency to 86 per cent. normal and 14 per cent. teratophthalmic. In the $B$ pieces the control shows no normals, 40 per cent. teratophthalmic, and 52 per cent. anophthalmic with 8 per cent. teratomorphic and headless together, while the rise in temperature alters this head-frequency to 56 per cent. normal, 42 per cent. teratophthalmic and only 2 per cent. of the lower types. In $C$ pieces a similar increase in head-frequency results from a rise in temperature. Table VII. shows a great decrease in head-frequency

\section{TABLE VIII.}

Worms Which Have Been Living for Almost Two Months in the Laboratory at Medium Temperature, Regulating at High.

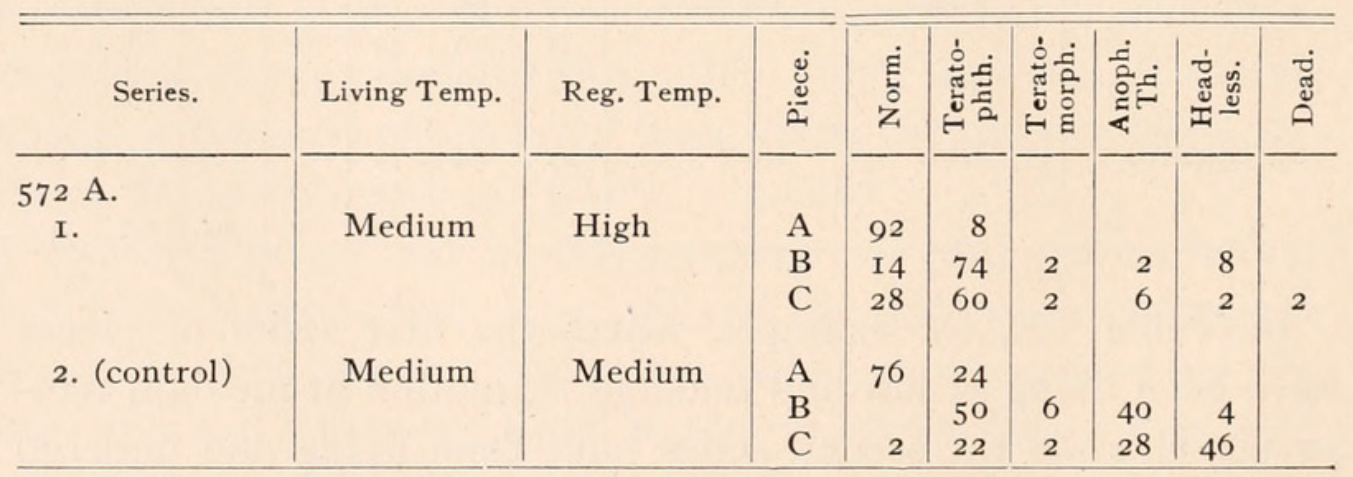

as the result of regulation at a lower temperature than the living temperature. And Table VIII. shows an increase in headfrequency as the result of regulation in a temperature higher than the living temperature. 
Let us consider briefly the significance of the data in the light of the interpretation of head-frequency suggested above. It will be seen that at a lowered temperature the head frequency throughout is lower than it would have been at the original temperature; at raised temperature it is higher than it would have been at the original temperature." Alteration of temperature then must affect $x$ more than $y$; for if this were not the case we should expect head-frequency to remain unaltered. Apparently, then, the $x$ cells are more susceptible to the direct effect of temperature changes than those of $y$.

This greater susceptibility of the $x$ cells to temperature change is also indicated by the fact that at $4^{\circ} \mathrm{C}$. the $x$ region is incapable in almost 100 per cent. of the cases of giving rise to any head at all; although if the changes in temperature have not been too rapid the pieces may still remain alive at this temperature. Pieces kept for some five months at this temperature remained headless; but when brought into medium temperature gave rise to a high percentage of heads, many of which were normal. At this extremely low temperature life was maintained, but little or no growth of the physiologically younger cells of $x$ occurred.

2. During the First Few Hours of Regulation.-Another series of experiments was conducted to see what would be the effect of temperatures applied for shorter periods of time than the whole time of regulation. These experiments were in a sense preliminary to acclimation experiments proper. They lie in intermediate position between those testing the direct effect of temperature during regulation and those testing the power of adjustment of the organism to temporary changes, and the extent to which such changes permanently alter the metabolic rate.

It has been found experimentally (Child, 'I $4 b$ ) that whether a head shall be formed or not is determined within $3^{-6}$ hours after sectioning. ${ }^{1}$ These experiments were repeated by me with like results (see Table IX. below).

We know that long pieces from standardized stock, such as $a-x$ (Fig. 6), produce practically Ioo per cent. normal heads. We also know that pieces such as $a-b$ (Fig. 6) whose anterior

\footnotetext{
${ }^{1}$ Similar data have been worked out for Lumbriculus inconstans by Hyman (' $16 a$ !
} 
ends are as nearly as possible at the same body level as the anterior ends of the long pieces give practically ioo per cent. headless forms. Moreover, we find that when a piece such as

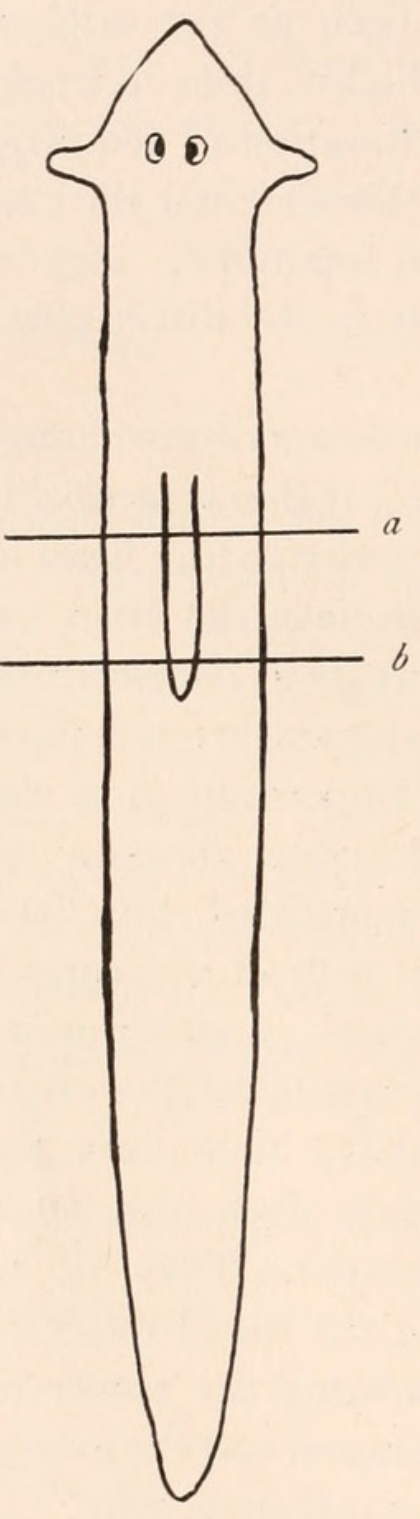

$x$

FIG: 6 . $a-b$ has remained for a few hours as the anterior portion of the long piece $a-x$ and is then isolated, it usually gives rise to a head. It is evident that at the anterior end of the piece conditions determining head formation have been so fixedly established during these few hours that they are not essentially altered by the later isolation of the short piece, although when the short piece is isolated at once head formation is inhibited.

The experimental procedure is as follows: A lot (A) of 25 or 50 long pieces $(a-x$, Fig. 6) are cut and allowed to regulate, and head-frequency noted. A second lot (B), short pieces ( $a-b$, Fig. $6)$, are likewise cut and allowed to regulate. These serve as controls. Several hundred long pieces ( $a-x$, Fig. 6) are now cut, and from the anterior regions of these, lots (C, D, E, etc.) of short pieces ( $a-b$, Fig. 6) are cut at different intervals following the first section. In this way the head forming region is left for a certain length of time as the anterior end of the long piece before it becomes the anterior end of the short piece. Table IX. gives the results of such a series of experiments.

Evidently the process of head determination then begins almost immediately after section and the conditions existing in the piece during the first few hours after section must constitute the most important factor determining the character of the result.

The controls $A$ give Ioo per cent. heads, whereas the controls 
TABLE IX.

\begin{tabular}{|c|c|c|c|}
\hline Lot. & $\begin{array}{c}\text { Length of Time Between Two Cuts, at } a \\
\text { and at } b .\end{array}$ & $\begin{array}{l}\text { Per Cent. } \\
\text { Heads. }\end{array}$ & $\begin{array}{l}\text { Per Cent. } \\
\text { Headless. }\end{array}$ \\
\hline $\begin{array}{r}\text { XXIV. A } \\
\text { B } \\
\text { C } \\
\text { D } \\
\text { E } \\
\text { F }\end{array}$ & 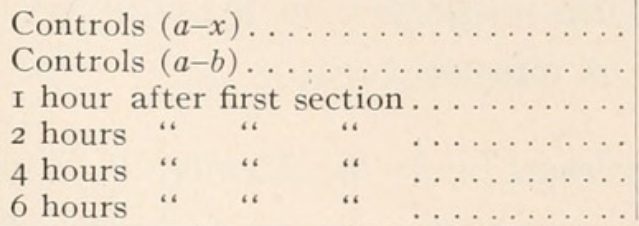 & $\begin{array}{r}\text { I } 00 \\
8 \\
40 \\
64 \\
88 \\
92\end{array}$ & $\begin{array}{r}92 \\
60 \\
36 \\
12 \\
8\end{array}$ \\
\hline
\end{tabular}

$B$ give only 8 per cent. heads, and in the lots $\mathrm{C}, \mathrm{D}, \mathrm{E}, \mathrm{F}$, cut from the anterior ends of the long pieces at different intervals, it is evident that head-frequency increases with the length of the interval and that 6 hours' connection with the long piece is a sufficient interval to form a head in 92 per cent. of the pieces.

The demonstration of the occurrence of head determination within so short a period of time furnished good ground for the belief that temperature, acting through similar periods of time, would be able to produce an effect upon head-frequency. A few experiments along this line were undertaken. Worms from medium temperature were cut and immediately put for three hours into low temperature, after which they were left to regulate at medium temperature, and their head-frequency compared with that of a medium temperature series not subjected to low temperature. The results of such a series of 25 worms are given below in Table $\mathrm{X}$. The death rate is somewhat high but the differences in head-frequency indicate some effect of the temperature change. Although these differences are slight, several repetitions of the experiments showed the same results, which are therefore to be considered typical.

TABLE X.

\begin{tabular}{|c|c|c|c|c|c|}
\hline Lot. & $\begin{array}{l}\text { Temp. for } 3 \text { Hrs. } \\
\text { After Cutting. }\end{array}$ & Reg. Temp. & $\begin{array}{l}\text { Heads, } \\
\text { Per Cent. }\end{array}$ & $\begin{array}{l}\text { Headless, } \\
\text { Per Cent. }\end{array}$ & $\begin{array}{l}\text { Dead, } \\
\text { Per Cent. }\end{array}$ \\
\hline $\begin{aligned} & \text { XIV. } 5 \\
& \mathrm{~A} \\
& \mathrm{~B} \\
& \mathrm{C}\end{aligned}$ & Medium & Medium & $\begin{array}{l}98 \\
74 \\
48\end{array}$ & $\begin{array}{r}2 \\
18 \\
52\end{array}$ & 8 \\
\hline $\begin{aligned} & \text { XIV. } \text { I } \\
& \mathrm{A} \\
& \mathrm{B} \\
& \mathrm{C}\end{aligned}$ & Low & Medium & $\begin{array}{l}88 \\
60 \\
40\end{array}$ & $\begin{array}{r}8 \\
34 \\
42\end{array}$ & $\begin{array}{r}4 \\
6 \\
\mathrm{I} 2\end{array}$ \\
\hline
\end{tabular}


From the above table it will be seen that the effect of lowering temperature during the beginning of the period of regulation is of the same sort as the effect of a temperature continued during the whole period. Head-frequency is lowered throughout the series by the lowering of temperature.

B. The Analysis of Acclimation by the Method of Head-Frequency.

In the experiments of the preceding section, worms were taken from temperatures at which they had been living so long that there could be no doubt that acclimation is practically completed. In this section worms were used which had been living at a given temperature for shorter periods of time before putting into a new temperature to regulate. In this way an attempt was made to determine for how long a period worms must live in one temperature before acclimation to that temperature occurs to such a degree that it will affect the head-frequency at a new temperature.

The method consisted in keeping worms at a certain temperature for various lengths of time, from three days to three weeks. Then cutting $\mathrm{A}, \mathrm{B}$ and $\mathrm{C}$ pieces for regulation at another temperature and comparing their head-frequency with that of pieces from animals living at the second temperature. A difference in head-frequency between the two lots will indicate that the first temperature has had some effect on the reaction to the second.

The following table gives a resumé of the results of such experiments with acclimation periods of from 3 days to 3 weeks.

Taking the first series as an illustration, the animals were kept at low temperature for three days and the $A, B, C$ pieces when cut were placed in medium temperature for regulation. The head-frequency of this series was then compared with that of a control series which had been living and underwent regulation at the regulation (in this case medium) temperature. In this first series the head-frequency of the worms kept at low for three days before the pieces were cut shows in the $A$ pieces a decrease, in the $B$ and $C$ pieces an increase in head-frequency as compared with the control. The data for the other series are recorded in the same way.

The table shows that the effect on head-frequency for shorter 
TABle XI.

\begin{tabular}{|c|c|c|c|c|c|}
\hline \multirow{2}{*}{ Series. } & \multirow{2}{*}{$\begin{array}{l}\text { Length and Temperature } \\
\text { of Acclimation Period. }\end{array}$} & \multirow{2}{*}{$\begin{array}{c}\text { Regulation } \\
\text { Tempera- } \\
\text { ture. }\end{array}$} & \multicolumn{3}{|c|}{$\begin{array}{l}\text { Head-frequency Compared with that of Worms } \\
\text { Kept and Regulating at Regulation Temperature }\end{array}$} \\
\hline & & & A. & B. & C. \\
\hline I & low, 3 days & medium & decrease & increase & increase \\
\hline 2 & low, 3 days & “. & & & “ \\
\hline 3 & low, 3 days & “ & “. & “. & “" \\
\hline 4 & high, 3 days & “ & “ & decrease & decrease \\
\hline 5 & low, 3 days & & increase & increase & increase \\
\hline 6 & medium, 3 days & high & decrease & decrease & decrease \\
\hline 7 & low, 4 days & medium & increase & increase & increase \\
\hline 8 & medium, 4 days & high & decrease & ... & "“ \\
\hline 9 & low, 4 days & & & “" & decrease \\
\hline Io & medium, I week & low & increase & $\overline{-}$ & “. \\
\hline I I & medium, I week & high & & increase & “ \\
\hline I 2 & low, I week & medium & decrease & & 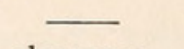 \\
\hline I3 & medium, 3 weeks & low & & decrease & decrease \\
\hline I 4 & low, 3 weeks & medium & increase & increase & increase \\
\hline I 5 & low, 3 weeks & high & & & \\
\hline I6 & medium, 3 weeks & high & increase & “. & “. \\
\hline I 7 & low, 3 weeks & high & “ & “ & “ \\
\hline 18 & low, 3 weeks & medium & “" & “" & “" \\
\hline 19 & high, 3 weeks & medium & decrease & decrease & - \\
\hline 20 & low, 3 weeks & medium & increase & increase & increase \\
\hline
\end{tabular}

periods up to one week is not entirely uniform; while with three weeks at the acclimation temperature, there is uniformity, headfrequency being higher than that of the control when the regulation temperature is higher than that of acclimation and vice versa. As might be expected, the head-frequency method of demonstrating the effect of acclimation is not as delicate as the other methods employed, and consequently longer periods of acclimation are required to give consistent and uniform results. Since the physiological methods have shown that at least some degree of acclimation to temperature occurs within a few hours (see pp. 307-8 above), it is evident that when pieces are brought into the new temperature for regulation the effect of any temperature to which they have been previously subjected will be more or less compensated by the beginning of acclimation to the new temperature even before head-frequency is determined. Consequently, this method can be expected to show only the larger effects resulting from longer periods of acclimation.

VII. Discussion.

The experimental data on susceptibility, on $\mathrm{CO}_{2}$ production as estimated both colorimetrically and by the biometer, and on 
head-frequency in regulation all agree in indicating that when individuals of Planaria dorotocephala are subjected to changes in temperature which are not too extreme, two sorts of change in metabolic condition are distinguishable. The first of these is the change in oxidation rate which is the direct effect of the change in temperature, and is either an increase or a decrease in rate according as the change consists in a rise or a fall in temperature. The second is a gradual process of acclimation extending over days or weeks and apparently gradually approaching a limit. This process involves an alteration opposite in direction to the first, consisting in a gradual decrease in oxidation rate if the change is from a lower to a higher temperature, an increase if the change is from a higher to a lower temperature.

That this alteration in rate is a real acclimation and not merely a recovery from the shock of a change in temperature is indicated first by the fact that extreme changes are not necessary to bring it about; second, by the fact that it occurs when the temperature is raised the same number of degrees gradually as well as when it is raised abruptly, and third, that it only begins to be appreciable after twelve hours or more and may extend over a period of weeks. Recovery from any shock that might conceivably result from a change of $10^{\circ}$ in temperature in an animal like Planaria might be expected to occur within a much shorter period of time than this acclimation process.

The acclimatory change in rate of oxidation, a decrease following rise, an increase following fall in temperature, represents the working of a regulatory mechanism which shows some resemblances in its results to the mechanism of temperature regulation in the warm-blooded animals. There, too, a rise in temperature brings about a decrease in rate of oxidation, and a fall, an increase in rate. It seems probable that a regulatory mechanism working in much the same way as that of Planaria will be found in other cold-blooded animals, and that such a general mechanism of acclimation to temperature in cold-blooded animals is the basis from which the temperature-regulating mechanism of warmblooded animals is developed and elaborated.

The main differences between a general mechanism of acclimation to temperature such as that of Planaria and a temperature- 
regulating mechanism such as that of warm-blooded animals seem to be that the former acts relatively slowly and only partially compensates the direct effect of temperature change; whereas the temperature-regulating mechanism acts very rapidly and maintains a uniform body temperature over a wide range of external temperature change.

Since the establishment of the fact that the usual temperature coefficient of velocity of chemical reaction for $\mathrm{IO}^{\circ} \mathrm{C}$. within ordinary temperature range is between 2 and 3 , and that the temperature-coefficients of many physical processes are of very different orders of magnitude, the temperature coefficients of various physiological processes have been determined on the assumption that such coefficients will show whether chemical or physical processes are primarily concerned. Snyder ('o8) found that the velocities of nerve impulses follow van't Hoff's law for chemical reactions. Van Slyke and Cullen ('I4) observed that the reaction rate of the enzyme urease is nearly doubled by every $\mathrm{Io}^{\circ}$ rise in temperature between $10^{\circ}$ and $40^{\circ}$, the average temperature coefficient being I.9I within this range. Loeb and Wasteneys ('II) investigated the temperature coefficient for the rate of oxidation in newly fertilized Arbacia eggs and found it to be remarkably constant, about 2. And Lillie and Knowlton ('97) showed the temperature coefficient for the development of the egg of the frog to be of the same nature as that for chemical reactions. A great number of other similar cases might be quoted. Yet with the increase in knowledge along this line it has become increasingly evident that caution is necessary in generalizing from such data; for not only are some of the chemical and physical temperature coefficients almost identical, but as Bayliss ('I5, p. 43) and others have pointed out, the physiological processes are processes occurring in heterogenous systems in which even when a chemical reaction occurs, other processes must also be concerned; and the velocity of the whole will be conditioned by that process the rate of which is lowest under the given conditions.

The experiments on temperature acclimation in Planaria show that in addition to the direct effect of temperature on the velocity of cer ain physiological processes, there is a secondary effect 
occurring gradually and proceeding in the opposite direction from the first; that is, after a change in temperature, the velocity of physiological processes must undergo a gradual progressive change apparently approaching a limit in a constant temperature. Such a change manifestly cannot be an effect of temperature on the velocity of chemical reaction, but must result from an action of the altered velocity and other temperature effects associated with it upon the constitution or condition of the heterogenous protoplasmic system. These changes in the system in turn condition further gradual alterations in the velocity of reactions even though the temperature remains constant.

The effect of temperature upon head-frequency suggests that the processes in the region $x$ (Fig. 5), the cells of which undergo extreme dedifferentiation and rapid growth and are directly concerned in head-formation, are altered to a greater degree by change in temperature than those in the region $y$. Regulation at a higher temperature than that at which the animal has been living increases, and regulation at a lower temperature decreases head-frequency. Moreover, acclimation to a given temperature alters the reaction, as indicated by head-frequency, to another temperature (Table XI.). This table also shows that animals acclimated to a high temperature show a lower head-frequency, and animals acclimated to a low temperature, a higher head-frequency, than those brought into that temperature at the beginning of regulation. These effects are in general opposite in direction to the direct effects of temperature change. If headfrequency $=\frac{\text { rate } x}{\text { rate } y}($ pp. $302-3)$, as various lines of experimental evidence indicate, it is evident; first, that changes in temperature must directly alter rate $x$ more than rate $y$; and second, that acclimation to a given temperature preceding regulation produces its effect by altering the metabolic level at which the regulatory processes in the cells of $x$ begin.

These conclusions are in complete agreement with other data on acclimation to temperature and to other conditions in Planaria. In general, direct susceptibility to change in conditions and also capacity for acclimation to conditions which are not too extreme vary with rate of oxidation (Child, 'I $3 a$, 'I $3 c$, 
I4a, I4c, 'I6). A physiologically young animal shows a higher susceptibility to change in conditions as indicated by direct effect, and also is able to become more rapidly and completely acclimated to changes which are not too extreme. The cells of $x$ undergo extreme dedifferentiation after section and become essentially embryonic cells before giving rise to a head. In an isolated piece then they very soon become physiologically younger than the cells of $y$, and the higher susceptibility of $x$ to temperature changes as well as the effects of acclimation are unquestionably associated with this change in physiological condition and increase in metabolic activity.

In short, the data on head-frequency not only indicate direct and acclimatory effects of temperature of the same sort as those indicated by susceptibility to cyanide and $\mathrm{CO}_{2}$ production, but they also indicate that these temperature effects are not the same for cells or tissues in different physiological condition. Here again the difficulty of drawing definite conclusions as to existence of a temperature coefficient of physiological processes is evident, from the fact that the rate of increase in the velocity of reaction may vary with the physiological condition of the cells or tissues concerned.

\section{Summary.}

I. The susceptibility of Planaria dorotocephala to toxic concentrations of KNC increases with rise and decreases with fall in temperature.

2. When animals which have been living at one temperature are subjected to another a gradual change in susceptibility to $\mathrm{KNC}$ in the new temperature occurs. In animals brought from a lower to a higher temperature the susceptibility undergoes gradual decrease at the higher temperature, and in animals brought from a higher to a lower temperature the susceptibility undergoes a gradual increase at the lower temperature. These secondary changes in susceptibility are distinguishable after twelve hours' subjection to a new temperature, but extend over days or weeks, apparently gradually approaching a limit. These changes occurring in a temperature higher or lower than that at which the animals have previously been living represent a process of acclimation. 
3. Estimations of $\mathrm{CO}_{2}$ production by a colorimetric method and by the Tashiro biometer give essentially the same results as the susceptibility method. The increase in $\mathrm{CO}_{2}$ production which occurs when animals are brought from a lower to a higher temperature is followed by a gradual decrease at the higher temperature; and the decrease in $\mathrm{CO}_{2}$ production which occurs when animals are brought from a higher temperature is followed by a gradual increase in $\mathrm{CO}_{2}$ production at the lower temperature.

4. Experiments on the effect of temperature on head-frequency in the regulation of pieces give results similar to those on susceptibility and on $\mathrm{CO}_{2}$ production. Rise in temperature increases, fall in temperature decreases, head-frequency, but acclimation determines changes in head-frequency in opposite directions from those directly determined by change of temperature. Animals which have become acclimated to a high temperature show a lower head-frequency in regulation than those brought in to that temperature at the beginning of regulation; and animals acclimated to low temperature show a higher head-frequency than those brought into that temperature at the beginning of regulation.

5. All the experimental data agree in indicating that, within the temperature range of the experiments, acclimation to a change in temperature upward consists in changes which manifest themselves physiologically as a gradual decrease in rate of metabolism or oxidation; and acclimation to a change in temperature downward consists in changes which manifest themselves physiologically as a gradual increase in rate of metabolism or oxidation.

6. The working of the regulating mechanism concerned in acclimation to temperature resembles as regards its action on metabolism the temperature-regulating mechanism of warmblooded animals, but is very much slower and less effective as a compensatory mechanism than the latter. It may perhaps be regarded as representing the general basis from which a temperature-regulating mechanism has developed. 
Aderhold, R.

\section{BIBLIOGRAPHY.}

'88 Beitrag zur Kenntniss richtender Kräfte bei der Bewegung niederer Organismen. Jena Zeitschr., XXII., pp. 310-342.

Bayliss, W. M.

'I5 Principles of General Physiology. Longmans, Green \& Co., London.

Child, C. M.

'I I S Studies on the Dynamics of Morphogenesis and Inheritance in Experimental Reproduction in Planaria dorotocephala. I., The axial gradient in Planaria dorotocephala as a limiting factor in regulation. Jour. Exp. Zoöl., X., 3 .

'Irb Studies in the Dynamics, etc. II., Physiological dominance of anterior over posterior regions in the regulation of Planaria dorotocephala. Jour. Exp. Zoöl., XI., 3.

'IIc Studies in the Dynamics, etc. III., The formation of new zooids in Planaria and other forms. Jour. Exp. Zoöl., XI., 3.

'IId A Study of Senescence and Rejuvenescence, based on Experiments with Planaria dorotocephala. Arch. f. Entw.-mech., XXXI., p. 537.

'ire Experimental Control of Morphogenesis in the Regulation of Planaria. Biol. Bull., XX., No. 6.

'rза Studies, etc. V., The relation between resistance to depressing agents and rate of metabolism in Planaria dorotocephala and its value as a method of investigation. Jour. Exp. Zoöl., XIV., p. I53.

'rзb Certain Dynamic Factors in Experimental Reproduction and their Significance for the Problems of Reproduction and Development. Arch. f. Entw.-mech., XXXV., p. 598.

'r3c Studies, etc. VI., The Nature of the Axial Gradients in Planaria and their Relation to Antero-posterior Dominance, Polarity and Symmetry. Arch. f. Entw.-mech., XXXVII., p. Io8.

'r4a Studies, etc. VII., The stimulation of pieces by section in Planaria dorotocephala. Jour. Exp. Zoöl., I6, p. 4I3.

'I4b Studies, etc. VIII., Dynamic Factors in Head Determination in Planaria. Jour. Exp. Zoöl., XVII., p. 6I.

'I4c Starvation, Rejuvenescence and Acclimation in Planaria dorotocephala. Arch. Ent. Mech., XXXVIII.

'I5 Senescence and Rejuvenescence. University of Chicago Press.

'r6 Studies, etc. IX., The Control of Head Form and Head-Frequency in Planaria by means of Potassium Cyanide. Jour. Exp. Zool., XXI., p. Io I.

\section{Dallinger, W. H.}

'8o On a Series of Experiments made to Determine the Thermal Death Pyint of Known Monad Germs when the Heat is endured in a Fluid. Jour. Roy. Micr. Soc., III., pp. I-I6.

\section{Davenport, C. B.}

'97 Experimental Morphology. MacMillan Co., New York, 509 pp.

Davenport, C. B., and Castle, W. E.

'95 Studies in Morphogenesis, III. On the Acclimatization of Organisms to Dieudonné, A. High Temperatures. Arch. für Entw., II., pp. 236-240.

'94 Beiträge zur Kenntniss der Anpassungsfähigkeit der Bakterien an ursprünglich ungünstige Temperatur-verhältnisse. Arb. a. d. kais. Gesndhtsmt., IX., p. 492. 
Dorfmeister, G.

'79 Über den Einfluss der Temperatur bei der Erzeugung der Schmetterlingsvarietäten. Mittheil. naturw. Ver. Steiermark. Jahrg. I879, pp. 3-8.

Ehrenberg, C. G.

'59 Über eine auf der Insel Ischia jüngst beobachtete zur Erläuterung einer ungarischen aus Kiesel Organismen bestehenden Felsart dienende Wirkung heisser Quellen. Monatsber. Akad. Wiss. Berlin aud d. Jahre I858.

Féré, C.

'94 Note sur l'influence de la Temperature sur l'incubation de l'oeuf de poule. Jour. de l'Anat. et de la Physiol., XXX., pp. 352-365.

Flourens, M. J. P.

'46 (Note on Conferva of Icelandic hot springs.) Comp. Rend., XXIII., p. 934 .

Geppert, J.

'89 Über das Wesen der Blausaürevergiftung. Zeitschr. f. klin. Med., Bd. I5.

Haas, A. R.

'I6 A Simple and Rapid Method of Studying Respiration by the Detection of Exceedingly Minute Quantities of Carbon Dioxide. Science, N. S., Vol.

Hofmeister, W. XLIV., No. II25, pp. 105-I08.

'67 Die Lehre von der Pflanzenzelle. Leipzig. Engelmann, 664 pp.

Hyman, L. H.

'I6a An Analysis of the Process of Regeneration in Certain Microdrilous Oligochaetes. Jour. Exp. Zoöl., XX., 2, pp. 99-163.

' $16 \mathrm{~b}$ On the Action of Certain Substances on Oxygen Consumption. Am. Jour. Phys., Vol. 40, 2.

Knowlton, F. P., and Starling, E. H.

'I2 Influence of Temperature and Blood Pressure on the Isolated Mammalian Heart. Jour. Phys., 44.

Lillie, F. R., and Knowlton, F. P.

'97 On the Effect of Temperature on the Development of Animals. Zoöl. Bull., I., pp. I79-193.

Loeb, J., and Wasteneys, $\mathrm{H}$.

'I2 On the adaptation of fish (Fundulus) to higher temperature. Jour. Exp. Zoöl., XII., p. 543.

Mayer, A. G.

'I7 Is Death from High Temperature due to the Accumulation of Acid in the Tissues? Am. Jour. Phys., XLIV., 4, pp. 581-586.

Nägeli, C.

'6o Ortsbewegungen der Pflanzenzellen und ihrer Theile. Beitr. z. wiss. Bot., II., pp. 59-108.

Rossbach, M. J.

'72 Die rhythmischen Bewegungserscheinungen der einfachsten Organismen und ihr Verhalten gegen physikalische Agentien und Arzneimittel. Verh. phys. med. Ges., Würzburg, I, pp. 179-242. Also in Arbeiten a. d. zoöl.

Sachs, J. zoot. Institut', Würzburg, I., 9-72.

'65 Handbuch Exp. Phys., p. 52.

Schottelius, M.

'87 Biologische Untersuchungen über den Micrococcus Prodigiosus. Leipzig. 
Schultze, M.

'63 Das Protoplasma der Rhizopoden und der Pflanzenzellen. Leipzig, Engelmann, 68 pp.

Schwartz, F.

'84 Der Einfluss der Schwerkraft auf die Bewegungsrichtung von Chlamidomonas und Euglena. Ber. bot. Ges., II., pp. 5I-72.

Snyder, C.

'08 The Temperature Coefficient in the Velocity of Nerve Conduction. Am. Jour. Phys., 22, p. I79.

\section{Tashiro, S.}

'I4 Carbon Dioxide Apparatus. III. Another special apparatus for the estimation of very minute quantities of carbon dioxide. Jour. Biol. Chem., XIX., p. 485 .

Treviranus, G. R.

'3I Versuche über das Atemholen der niederen Tiere. Unters. über d. Natur. d. Menschen, d. Tiere, u. d. Pflanzen. (Tiedemann \& Treviranus), IV., pp. I-39.

Van Slyke, D. D., and Cullen, G. B.

'I4 The Mode of Action of Urease and of Enzymes in general. Jour. Biol. Chem., XIX., p. I4I.

Velten, W.

'76 Die Einwirkung der Temperatur auf die Protoplasma-bewegung. Flora LIX., pp. I77-I82, I93-I99, 209-217, April-May.

Verworn, M.

'99 General Physiology. Transl. by F. S. Lee, London. MacMillan \& Co., 6 5 pp. (pp. 389, 390).

\section{Weismann, A.}

'95 Neue Versuche zum Saison-Dimorphismus der Schmetterlinge. Zoöl. Jahrb., Syst., VIII., p. 4I et seq. 



\section{BIOLOGICAL BULLETIN}

THE RELATION OF THE EMBRYO TO THE PRINCIPAL AXIS OF SYMMETRY IN THE BIRD'S EGG.

GEORGE W. BARTELMEZ,

From the Department of Anatomy, The University of Chicago.

Contents.

I. The Fundamental Relations of the Various Parts of the Bird's Egg.... 319

II. Historical Review. . . . . . . . . . . . . . . . . . . 324

A. The Principal Egg Axis ...................... 324

B. The Air Space............................. 324

C. The Shell Pigment............................. 333

D. The Chalazæ............................. 325

E. Ligamentum Albuminis........................ 328

F. The Long Axis of the Yolk .................... 328

G. The Oviducal and Ovarian Orientation.............. 334

H. The Relation of the Embryo to the Principal Egg Axis: Axis Angle............................... 335

III. Axis Angles in the Pigeon's Egg... . . . . . . . . . . . . . . . . 339

IV. Discussion........................... 347

A. Variability in Axis Angles. . . . . . . . . . . . . . 347

B. Inversions .............................. 349

C. Variability in the Chalazæ..................... 353

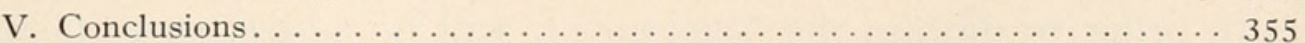

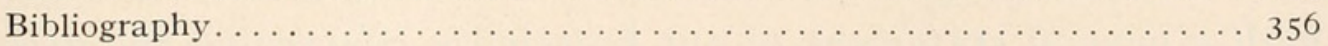

While studying the earliest stages in the development of the pigeon's egg some years ago it became necessary to devote some attention to the laid egg. Here I found several relations of fundamental importance which recent embryologists have consistently neglected. It was especially interesting to find that the well-known relation between embryo and egg as a whole (Fig. I) is subject to much greater variation than is generally believed. This became still more striking when it was found that the eggs of a single bird vary less than the eggs obtained from a group of birds. The present report covers observations extended over a much longer period than my former one (I9I2), together with an analysis of the data and the literature. 
I wish to call particular attention to the older studies on the bird's egg. From the time of Aristotle until the work of Kölliker, O. Hertwig and van Beneden began, the only accredited and accessible embryological material was afforded by the hen's egg and a wealth of observation was accumulated concerning it. Yet recent students of the bird's egg have dated their work from Gegenbaur's paper in I86I assuming that the monumental researches of Harvey, Malpighi, Wolff, Dutrochet, Coste and even Purkinje and von Baer have now only an historic interest. The folly of this will appear from what follows. These workers, unhampered by our elaborate technical methods, studied this macroscopic egg with the thoroughness of studious leisure and then wrote of it in a manner that must arouse the wonder and admiration of any embryologist today. The neglect which Purkinje has suffered can be explained at least in part, but the oblivion in which v. Baer's work still languishes is incomprehensible.

The findings reported here are significant not alone in illuminating the nature and causes of the variability in the relations of the axes of bilaterality. They have also a direct bearing upon all descriptive studies of the earliest stages of the bird's egg and they must especially be taken into account in the interpretation of experimental studies of stages preceding the appearance of the primitive streak.

In order to discuss the literature it will be necessary to begin with a general statement of our knowledge concerning the axes of the bird's egg, working backwards from the incubated egg to the ovarian oöcyte.

After the appearance of the primitive streak the bird's egg presents two obvious axes of symmetry; one a general axis of the egg as a whole, the principal axis, the other the axis of the embryo itself. Both of these are more or less apparent in other eggs, especially the highly meroblastic eggs of reptiles and selachians, but so far as is known it is only in birds that these two axes are definitely related to one another. The fact that they are related indicates that they are expressions of the same (bilateral) symmetry of the organism-a thesis for which I brought forth abundant evidence in I9I2. Unfortunately we 
have few data as to the relation of the two axes in birds other than the hen and pigeon but such observations as we do have indicate that many if not all birds' eggs show the same general relations. Duval in 1884 assumed this to be true but he never published any evidence.

The principal egg axis is defined by the form of the secondary egg envelopes. In addition to the obvious difference between the two ends of the shell, the ends of this axis are differentiated by even more constant characters like the position of the air space, pigment distribution in certain forms, and less dependable

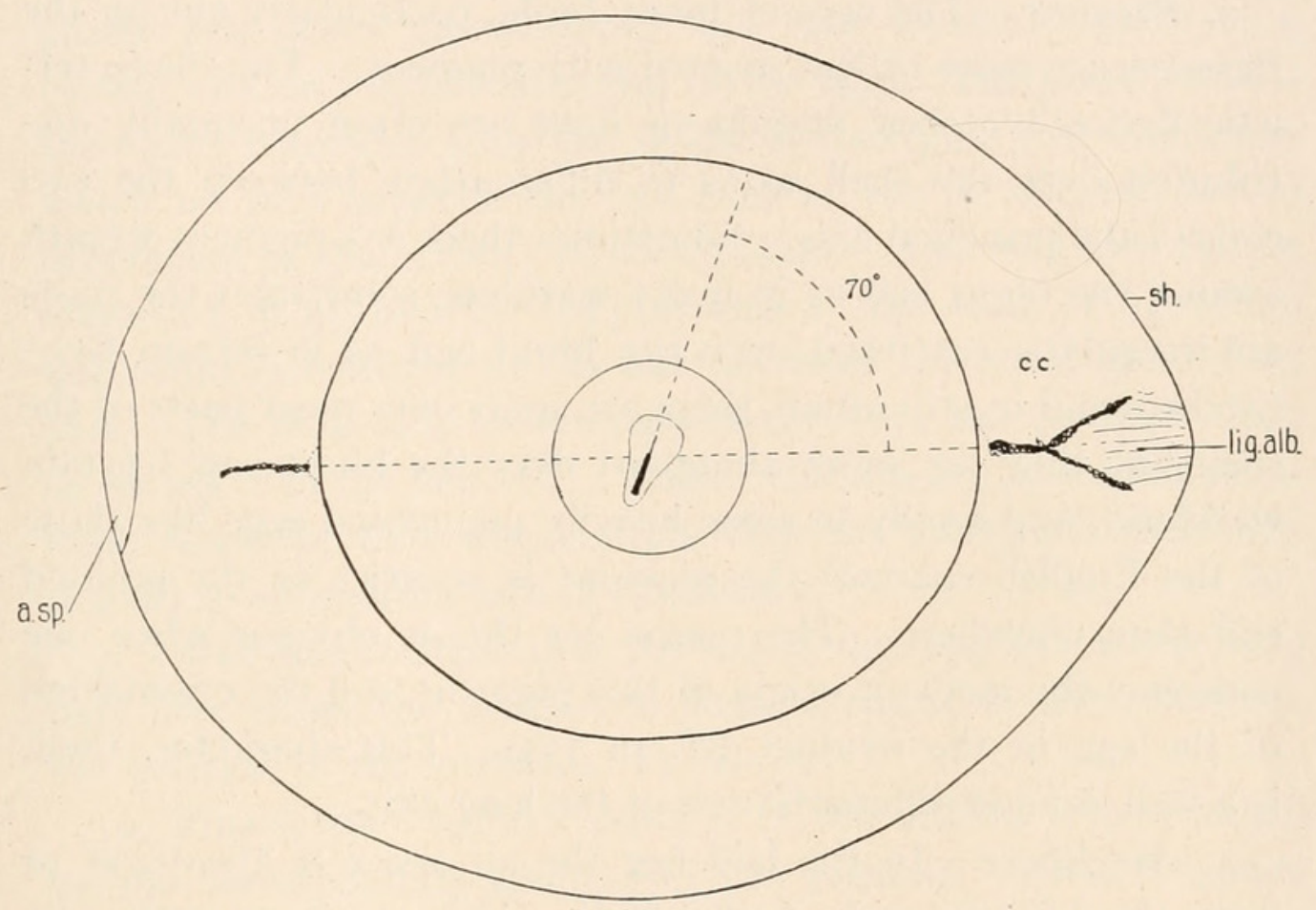

FIG. I. A diagrammatic polar view of an entire pigeon's egg showing the relation between the embryonic axis and the various features of the principal egg axis. The right side of the embryo is nearer the end of the egg which passed first down the oviduct, $i$. e., the pointed end of the shell. In the "uterus" the pointed end of the shell is directed toward the cloaca, the blunt end with the air space toward the infundubulum of the oviduct. The principal egg axis, ( $-(-)$ is marked by the major axis of the shell, the air space (a.sp.), the ligamentum albuninis (lig.alb.), the chalazal axis (c.c., cloacal chalaza), and the long axis of the ovum.

characters such as the size differences between the chalazæ. All of them are expressions of the structure and activity of the oviduct and their relations are constant because the egg is definitely oriented in the oviduct. As this point of view is new 
it is necessary to call to mind these characters and their relations to one another.

The two ends of the principal egg axis are differentiated by the following characters:

I. The relation of the embryo to the principal axis is such that its right side is nearer one end of this axis, its left side nearer the other.

2. Shape of Shell.-The two ends of the shell differ from one another in the eggs of most birds so that we may usually speak of a blunt and a pointed end.

3. Pigment.-The eggs of many birds, particularly among the Passeres are more or less spotted with pigment. The characteristic flecks, blotches, streaks or lines are often unequally distributed over the shell so as to differentiate between the two ends of the principal axis. Sometimes there is a pigment wreath around the blunt end as in many warblers, sometimes the spots are irregularly scattered over the blunt end as in certain flycatchers and in still others there are spots over most parts of the shell but they are more abundant over the blunt end (certain warblers), and finally in some heavily pigmented eggs like those of the English sparrow the pigment is scantier at the pointed end than elsewhere. The reason for this is obvious when one considers the mode of origin of this pigment and the orientation of the egg in the oviduct (cf. p. 333). This character, then, is a well-defined differentiation of the long axis.

4. Air Space.-In the laid egg the air space is always at or near the blunter end of the shell. This is an exceptionally constant character.

5. Chalaza.-The chalazæ are normally attached to the yolk in the line of the principal axis so that the chalazal axis is merely another expression of this axis. Furthermore, one often finds that one chalaza is larger and more distinct than the other. It is almost invariably the one at the pointed end of the shell. During incubation the blunt end chalaza is more likely to become detached or to disappear entirely; that is to say it reverts more readily to the sol phase.

6. Ligamentum Albuminis.-The second or thicker albumen is more or less firmly attached to the inner shell membrane, 
usually at both ends of the shell but this prolongation through the outer thin albumen is more marked at the pointed end in the laid egg. This prolongation Tredern fancifully called a "ligament."

7. Long Axis of Yolk.-The striking fact that the yolk (ovum) is not a sphere has been generally overlooked. One of its axes is greater than either of the other two and this axis is perpendicular to the polar axis and coincides with the principal axis.

8. The Oviducal Orientation.-All of our evidence points unmistakably to the conclusion that the pointed end of the egg passes first down the oviduct. We may therefore speak of a cloacal and an infundibular end of the egg. The principal axis therefore, coincides with the oviducal axis and the differences which we find between the two ends of the former are due to differences in the activity of the oviduct. The long axis can be identified in all ovarian oöcytes and at the time of ovulation the ovum is oriented in the oviduct with reference to its long axis. The long axis accordingly determines the principal axis as we see it in the laid egg. These relations are of fundamental importance for they demonstrate that the embryo is definitely related to an ovarian axis of symmetry.

9. I was able to show that the end of the long axis which is to pass first down the oviduct is predetermined in the ovary by the position of the latebra of Purkinje.

I0. Finally the eccentric position of the latebra is determined by the corresponding position of the germinal vesicle in young oöcytes.

In view of these facts we may express the relation between egg and embryo thus: The right side of the embryo is nearer that end of the principal egg axis which is predetermined in the ovary to pass first down the oviduct. This holds of course only for stages previous to the turning of the embryo on its side. To state the case in the more usual way we should say: If the end of egg which is predetermined to pass first down the oviduct be held to the observer's right the head of the embryo will be directed away from him. The presence of an axis of symmetry in the ovarian oöcyte so definitely related to the embryonic axis naturally led me to look for morphological evidences of the embryonic axis 
itself. The evidences I found in ovarian and oviducal eggs were enumerated in my I9I2 paper and I hope soon to publish the details of these observations.

\section{Historical Review.}

A. The Principal Axis of the Egg.-Aristotle devoted much attention to the hen's egg and he speculated at length upon the difference between the two ends of the shell. The Aristotelian doctrine, which is to be found elaborated even in some relatively recent papers may be stated as follows: The ovum drops into the oviduct as an apple from the tree; the ovarian pedicle of the oöcyte becomes the pointed end chalaza which passes last down the duct and the theca folliculi becomes the shell membrane. The pointed end is the "principium ovi, where the first rudiments of the egg are fashioned." This philosophy was based chiefly upon two observations of Aristotle's: The ovarian stalk or pedicle is characteristically long in the hen's oöcyte and the blunt end of the egg is laid first. Harvey's account of the early development is the first clear and accurate one for he understood the nature and destiny of the "cicatricula." He was able therefore to correct the error concerning the "principium ovi" as well as many others which his predecessors had made. However much he chuckled over the blunders of others, Harvey was always at some pains to explain or extenuate the errors of the Great Master. His discussion of Aristotle's statement that the shell does not harden until it reaches the outer air is well worth reading (I65I, Exercitatio XI.).

B. The Air Space.-Harvey was the first to observe the air space carefully; he found it at or near the blunt end of the hen's egg and he cites a common belief that if it is at the center of the blunt pole a male will be produced. He describes it as very small at laying, growing larger as incubation advances. v. Baer (I828) was the first to note that it is not present at all in oviducal eggs nor at the moment of laying. Coste ( 1847 , p. 306) is the only one apparently, who has seriously considered the problem of the air space. He confirmed v. Baer's observations and showed that as the egg cools after laying atmospheric air enters through the shell and forms the space between the two layers 
of the shell membrane. He did this by killing a hen that was about to lay, ligațing the uterus at either end and immersing the whole in a dish of oil. The uterus was then removed and the next day an oil-filled cavity was found in the place of the air space. But why should this space always arise at the blunt end? Coste was able to produce it under any part of the shell by a modification of his procedure. If, instead of removing the uterus under oil he clipped a window in it (thus exposing any given area of the shell) he obtained a typical oil-filled cavity under the window between the shell membranes. He was not able to explain why it normally forms where it does. Valentin (I835, p. 30) had previously attributed the formation of the air space to the puckering of the oviducal walls at the junction of "isthmus" and "uterus." He cites Purkinje to this effect but I have not found any mention of the matter in either edition of his paper. The region of the shell where the space forms is obviously more porous, quite possibly for the reason which Valentin gives. I have made some preliminary tests and am inclined to think that the shell cuticle is concerned in this localization.

It would be interesting to know whether there is any connection between the position of the air space and the fact noted by Murray (I826) that the temperature of the albumen at the blunt end is higher than that of the other.

All birds' eggs which I have examined have the air space at or near the blunt end of the shell. This holds for all pigeons' eggs in which a more pointed end is distinguishable. Some pigeons' eggs, as Coste noted, have equally rounded ends. In such eggs we find the head of the embryo turned away when we hold the air space end to our left. The practical importance of this for the present study is obvious (see p. 34I).

C. Shell Pigment.-See discussion on p. 333.

D. The Chalaze.-v. Baer says (1837, p. I8), "ueberhpaut ist nichts im Ei so wechselnd als die Hagelschnüre." Previous to I 850 this variability gave occasion for much study and controversy concerning chalazæ. The earliest workers were quite in the dark as to their nature. Aristotle was the first to refer to them and he thought one of them identical with the stalk of the 
ovarian ovum as has been said. The echoes of this opinion did not die out until quite recently; witness the belief that the inner shell membrane is identical with the theca folliculi interna of the oöcyte, an idea advanced by Pander (I8I8), Meckel v. Hemsbach (I85I), Mayer (I865), Nathusius (I885) and others. Needless to say none of these workers had any accurate knowledge of the oviducal egg of any bird. The theory was however not conclusively refuted until I884 when Tarchanoff succeeded in inserting an amber bead into the oviduct of a laying hen and twenty-four hours later found it surrounded by albumen, shell membrane and shell (cf. Curtis, I9I4).

Aldrovanus considered the chalazæ to be the sperm of the cock and Fabricius ab Aquapedente (I625) had a similar idea for he supposed that they were added at the time of fertilization. He considered one of them as the first rudiment of the embryo and drew excellent figures of chalazæ which have a ludicrous resemblance to chick embryos of the fourth day. Wolff in 1764 confesses to having made the same error in his own juvenile studies of the hen's egg. Harvey was the first to give a correct account of the nature and functions of the chalazæ. However he says that the chalaza at the blunt end of the egg is greater and longer than the other, differing in this from all subsequent observers.

A word should be said at this point concerning the various layers of albumen found in the bird's egg. Immediately surrounding the yolk and intimately fused with the vitelline membrane is the chalaziferous albumen which is continuous with the chalazæ. Around this is a layer of fluid albumen which makes possible the independent rotation of the yolk. Next follows the dense albumen which at laying is attached to the shell membrane at either end of the shell (ligamentum albuminis) so that the chalazæ are surrounded by the dense albumen. The space between this layer and the shell membrane is filled for the most part by a very fluid albumen which runs out as soon as the shell is opened. The inner thin albumen is difficult to identify in the laid egg of the hen (cf. Curtis and Pearl, I9I2, p. I02) but Doctor Blount tells that this albumen is very obvious in the "uterine" egg of the pigeon. This is obviously an egg in which the origin of the chalazæ can be most readily studied. 
The development of the chalazæ was first described by Dutrochet (I8I8-I9). His work was confirmed and extended by Purkinje (I825), v. Baer (I 828 and 37) and Berthold (I829) among others. The albumen which at first surrounds the newly escaped ovum forms a thin but dense layer over its surface. This albumen is probably secreted according to Curtis (I9I5) in the infundibulum and neck of the duct. It coagulates into the membrana chalazifera Dutrocheti and is shortly so firmly united with the vitelline membrane that they cannot be separated. "The tendency, says v. Baer, of albumens in contact with solids to coagulate is well known." The chalaziferous membrane is directly continuous with strands of albumen which were secreted into the lumen of the oviduct above and below the ovum. These strands, attached as they are to the ovum, become the chalazæ. According to Coste (I 847 , p. 29I) the ovum is not free to orient itself with reference to gravity until a fluid layer forms between the chalaziferous albumen and the inner dense albumen probably during the period of shell formation in the "uterus." This might happen while the thin solution of albumen is passing through the developing shell as described by Pearl and Curtis (I9I2). While in the uterus the egg is constantly being turned on its long axis and the ovum is constantly tending to orient itself with reference to gravity since the animal pole is specifically lighter than the yegetal. Consequently the chalazal strands attached to the yolk become twisted in opposite directions and as a result there is a partial coagulation of the chalazal albumen resulting in the "hailstones."

The stage at which the yolk is first free to rotate independently of the surrounding thick albumen and the time when the chalazæ as such become visible have not been satisfactorily determined. The nature of the space, too, between the chalaziferous albumen and the inner albumen which makes the rotation possible is most obscure. The suggestion of Taschenberg (1885), that the twisting of the chalazæ takes place before the egg enters the uterus is highly improbable. Not infrequently in the hen and pigeon at least, there is more chalazal albumen below the ovum than above it as Purkinje first noted (I825) and consequently the cloacal chalaza is larger than the other. This condition may play 
a part in the differentiation of the two ends of the shell. I have records of 14 oviducal pigeon eggs which had more albumen cloacally of the ovum but no instance of the converse. Many observers have noted for the hen that the pointed end chalaza may be larger than its mate in the laid egg. Thus: Maitre Jan (I722, p. I6), Leveille (I 799, p. 53), Vicq d'Azyr (I805) who says that the chalaza at the pointed end is "ordinairement" greater than the other, as well as Purkinje (I830, p. I8), v. Baer (I828), Berthold (I829) and Coste (I847, p. 293). Occasionally the infundibular chalaza is wanting in the incubated egg or is represented by a small button or cap of denser albumen (cf. Dutrochet (I8I8), Purkinje, I 830, p. I8). My own observations for these points are tabulated on p. 354. Since any difference in size or distinctness of the chalazæ is practically always in favor of the cloacal (pointed end) chalaza, we may say that a difference in the chalazæ is a frequent differentiation of the principal axis.

E. Ligamentum Albuminis.-Tredern's original description of the ligamentum albuminis occasioned much interest and controversy soon after its publication in $\mathrm{I} 808$ but recent generations seem to have forgotten it entirely. It is familiar to all who have opened fresh eggs at home with a view to strict economy. It should be said that usually it cannot be made out in stale or incubated eggs; there is in fact the same reversal from gel to sol phase in the denser albumen which may occasionally be observed in the chalazæ. This tendency is much more marked in the sparrow's than either the hen's or the pigeon's egg so far as my observations go.

F. The Long Axis of the Ovum.-There are two opinions as to the shape of he yolk of the bird's egg. One is the common traditional view, namely, that it is a sphere. Thus Harvey, transcribing his discussion of the yolk largely from Aristotle describes its shape as "perfectè rotundus." Likewise Haller (I758) and Vicq d'Azyr (I805) refer to "la forme spherique du jaune." Pander is one of the careful observers who makes a similar statement and even in Coste's beautiful figures (I 847), the outline of the yolk is always a circle. Purkinje himself seems to intimate that the yolk in the laid hen's egg is spherical as his collaborator Valentin (I835) did and as most moderns do, to 
judge from their diagrams. Other workers seem to have doubted this tradition. Bonnet ( $\mathrm{I} 762$ ) says, "La jaune est un grand sac, a peu pres rond" and Home (I 822) comments upon the "oval shape of the yelk." The figures in Tredern's paper and in Duval's Atlas (I 888) show the long axis. Now far from being spherical the yolk has not only a longest axis perpendicular to the polar axis but it is usually somewhat flattened at the animal pole so that the polar is its shortest axis. von Baer was the first to describe accurately and understand the significance of the shape of the yolk. Two passages are particularly worth quoting. They were written soon after the appearance of the first part of his great "Ueber die Entwickelungsgeschichte der Thiere" in I 828 although they were not published until i 837 . Thus on page I4 he says: "Ihre (der Dotterkugel) Form ist nicht völlig kugelig, sondern ellipsoidisch, indem ihre längste Axe wie die längste Axe des Eies gerichtet ist." Again, page 29, "Da die Dotterkugel im Eierstocke so liegt, dass die Keimschicht fast immer dem Stiele des Kelches zugekehrt ist, da ferner die trichterförmige Mündung des Eileiters den Kelch von der Seite umfasst, so tritt die Dotterkugel in solcher Lage in den Eileiter ein, dass die Keimsicht nicht vorn oder hinten ist, sondern an der Seite. Vorzüglich wird aber diese Stellung dadurch bedingt und mehr gesichert, dass diejenige Axe, die von der Keimsicht durch den Mittelpunkt des Dotters geht, auffalend kürzer ist als die senkrecht auf dieser Axe stehende. ${ }^{1}$ Letztere wird daher bald in die Längenrichtung des Eileiters gestellt werden, wie auch der Dotter eingetreten seyn mag.

This remarkable description, which may be confirmed by anyone who will make careful measurements, has been almost universally ignored. While $\mathrm{v}$. Baer was the first to see that the ovum orients itself with reference to its long axis in the oviduct-

\footnotetext{
${ }^{1}$ Hiernach wird es auch verständlicher, warum die Keimschicht, wenn sie nicht in der Nähe des Stieles vom Kelche ist, sich zuweilen in der Narbe zeigt. Sie bleibt nämlich im Kleinsten Kreise des Dotters. In ganz kleinen Eiern von der Grösse eines Hirsekornes habe ich diese längliche Gestalt nicht mit Sicherkeit zu erkennen vermocht. Sollte sie schon da seyn, so könnte man vielleicht sagen, dass das Keimbläschen gegen die nächste Stelle der Oberfläche des Eies sich bewegt und eben deshalb die Centralhöhle, als urpsringlicher Sitz des Keimbläschens, der Keimschicht (einer Wirkung des Keimbläschens) näher liegt, als der entgegengesetzten Seite. (See Bartelmez, I912, pp. 287 and 295.)
} 
he thought after ovulation, it must nevertheless be remembered that practically every objective drawing of an entire ovarian oöcyte shows a well-defined long axis. Pfeil describing a mature oöcyte of the hen in I823 says ". . . vitello in sacco scilicet rotundo, globoso" and Purkinje in I 825 (p. I) mentioned the 'somewhat oblong' shape of the young oöcytes. He saw also the elongate shape of the mature oöcyte but thought it was due to the pressure of the oviduct (see pp. 9 and 20, I830 edition).

Allen Thompson (I839) and Balfour (I874) completely confirmed von Baer's description while several workers have described the long axis in ovarian oöcytes of the hen without recognizing its significance. The following may be mentioned: His (I868), Nathusius (I868), Sonnenbrodt (I908) and Riddle (I9I I).

The observations of Haswell ' I 887) are particularly significant in this connection. With $\mathrm{v}$. Baer's description in mind he studied the egg of the emu, found the yolk measuring $70 \times 75 \mathrm{~mm}$., the long axis coinciding with the principal axis and the relations of the embryo as they are in the hen. He found the yolk ovoid rather than oval in shape, the more pointed end corresponding to the pointed end of the shell. I have occasionally seen the same condition in the pigeon's egg, but in this form attached no particular significance to it, as in some such cases the more pointed end was directed toward the blunt end of the shell.

In the pigeon the yolk is more markedly elliptical than in the hen and since it does not lose its shape through imbibition of albumen during the first two days of incubation as the hen's egg is apt to do, the long axis can hardly escape notice. It averages ten per cent. longer than the other axes of the yolk (see p. 342). It was a matter of no small gratification to find three years after writing it that I had almost duplicated v. Baer's description of the orientation of the hen's egg in my account of the pigeon's egg (I9I2). In his day the problems of bilaterality had not yet come to the fore and so he did not take the next logical step and point out the significance of the fact that the embryonic axis is definitely related to the ovarian long axis.

In most pigeon's eggs we find the polar axis the shortest; that is, in addition to being shorter than the long axis, it is usually shorter than the axis perpendicular to these two - which I term the transverse axis (Bartelmez, I9I2, p. 290 and p. 342 
below). Haller made mention of this in $175^{8}$ and Féré (1897) has called particular attention to it.

G. The Oviducal Orientation.-How does the egg lie in the oviduct? What is the relation of the principal egg axis with its differentiations to the axis of the oviduct? This has always been a matter of interest and it has been very naturally associated with the question as to which end of the egg is laid first. Aristotle says the blunt end is laid first and his whole argument concerning the "principium ovi" seems to assume that this end passes first down the oviduct. Purkinje published the data for the understanding of this matter in I 825 (see especially pages $2 \mathrm{I}$ and 22 of the 1830 edition) and he was fully confirmed by von Baer (I828-I837) and Coste (I847), but this was all forgotten and the question was discussed in the seventies and eighties to little purpose. It was finally put to rest by Wickmann in $\mathrm{I} 895$.

It should be said first that all observers who have made extensive studies of oviducal stages in birds agree that the pointed end passes first down the oviduct. For the hen the following may be cited: Purkinje (I 825 ), von Baer (I 828), Coste (I 847 , p. 293), Kütter (I878), Taschenberg (I885), Wickmann (I895) and Patterson (I9I0). In the pigeon the pointed end when recognizable was always found to be cloacal by Blount (I909) and Patterson (I909), each of whom studied about I50 oviducal eggs, and this has been my own experience. The same conditions have been reported for a hawk by Kütter (I878), the canary and various other birds by Wickmann (I895). It may be said in passing that Meckel von Hemsbach announced in $185 \mathrm{I}$ that it was a mathematical necessity for the blunt end to pass first down the oviduct! J. A. Ryder (I893) has also worked out the mechanics of shell formation on this basis.

There are however numerous observations which leave no doubt but that the blunt end of the hen's egg is usually laid first as Aristotle said. Nathusius gathered data in I885 and obtained only a single authentic record of the pointed end having been laid first. Landois (I877), König-Warthausen (I 885), Jasse (I886) and Erdmann (I886) all gave evidence from direct observations or from the direction in which the blood streaks of pullet's eggs were rubbed, that the blunt end is laid first. Nathusius (1885) reported a series of observations by Frau A. Ernst 
in Caracas upon 48 eggs laid on coal soot. It was clear that in every case the blunt end had been laid first.

It was assumed by these writers that the egg is forced out of the uterus in the act of laying by a simple peristalsis and hence that the blunt end passes first down the oviduct. Wickmann (1895) made direct observations upon the laying of eight hens and found that in most cases the blunt end is laid first; one hen however laid five successive eggs with the pointed end first. If the bird is taken some time before an expected laying the egg is always found with the pointed end cloacal, but, as both Purkinje and v. Baer noted, if she is killed near the time of laying either end may be directed toward the vagina. Purkinje suggested that during "labor" the egg was turned about its long axis until its position became "comfortable." He figured the oviduct of a hen with an egg in the "uterus" (Tab. II., Fig. I9), which shows the pointed end so held in a diverticulum of the duct that it is to the right and below the opening of uterus into vagina. Consequently the constant peristaltic movements of the duct rotate the egg without tending to drive it into the vagina. Wickmann (1895) was the first to analyze the whole process of laying. He demonstrated in a striking manner that in laying the egg is rotated about its shortest axis so that one end or the other lies opposite the opening into the vagina. Usually it is completely rotated so that the blunt end comes to be cloacal, occasionally there are birds in which the rotation is slight and the pointed end remains cloacal. Now a surprising thing happens. The egg is not simply forced out through the vagina as a mammal is born. The uterus still enveloping the egg is prolapsed through the vagina and the egg is laid without having touched the walls of either vagina or cloaca. Which end is laid first then depends upon chance or the peculiarities of the individual oviduct. There is then nothing to militate against the evidence that the end of the egg corresponding to the pointed end of the shell passes first down the oviduct and we may accordingly refer to this end as the cloacal end of the egg. Taschenberg (I894) states that certain individuals of Corvus frugilegus are apt to lay eggs with the pigment wreath at the pointed end of the shell, instead of the blunt end and that eggs may be found lying 
inverted in the "uterus" of this species. In such cases it is probable that the egg is rotated late in its uterine history.

Shell Pigment.--The unequal distribution of the pigment can now be discussed. While the method of distribution has been worked out satisfactorily, the origin of the pigment still remains obscure. As this field is terra incognita to most embryologists and ornithologists it is worth a digression. Wicke in 1858 laid the foundation for the understanding of the matter. He discovered that the pigment spots which are various shades of red or green, are closely related to or identical with the blood pigments bilirubin and biliverdin. Leuckart (I853) suggested that they might be derived from blood extravasated from the hyperæmic oviducal vessels. Kütter (I878) made the first direct observations on the subject. He found in the "uterus" of a Falco tinnunculus an unpigmented egg, although the eggs of this species are normally deeply pigmented. Scattered over the surface of the oviduct were small red-brown masses presumably passing down, for in other oviducts he found similar masses being incorporated into the outer layers of the shell. He suggested that these pigment masses were secreted in the upper part of the duct. In I 885 Taschenberg confirmed these observations and showed that there are no pigment glands in the oviduct, confirming Nasse's (I 862) previous observations. He concluded therefore that the pigment must be derived from the follicle at the time of ovulation. He pointed out for the first time the significance of the greater massing of pigment at the blunt end with reference to the passage of the pigment down the duct and the normal position of the egg in the uterus. It is obvious therefore that the unequal distribution of the pigment clearly marks the principal egg axis and shows that in all cases where there is unequally distributed pigment, the egg is oriented as it is in the hen and pigeon. In I 893 Wickman published a monograph on the pigment of the shell dealing with numerous species, confirming Kütter and independently reaching conclusions similar to those of Taschenberg. He did not however obtain any conclusive evid nce for the origin of the blood pigment from the ruptured follicle. This is an opportunity for an exceedingly interesting study involving also the nature of the oxidations of the blood pigments. 
The Oviducal Orientation.-We have seen that one end of the principal axis may differ from the other in regard to the shape and pigmentation of the shell, the position of the air space, the ligamentum albumenis, in the size and character of the chalazæ, and the relation of the egg to the oviduct. The vital link in the evidence for the thesis that the principal axis is an expression of an ovarian axis of symmetry was obtained when it was found that the end of the long axis of the yolk which is to pass first down the oviduct is predetermined in the ovary (Bartelmez, I9I2, p. 292 ss). In the pigeon at least, the latebra of Purkinje is, like the blastodisc, lighter than the mass of yellow yolk. Purkinje (I830, p. 7) believed the converse for he was much struck by the resemblance of his "fluid-filled cavity" to a plummet and did not make any tests. He did know however that the contents of the latebra have the same histological structure as the white yolk about the blastodisc. His figure (Tab. I., Fig. I6) of a median section of the yolk of a hen's egg shows the center of the latebra nearer the animal pole than the vegetal. This is still more marked in the pigeon's egg (see Bartelmez, I9I2, figs. 38 and 39). This specifically lighter latebra is nearer one end of the long axis than the other end and so one end of the ovum gravitates toward the cloaca and is received first into the oviduct as was described in my I9I 2 paper. It is worth noting that in three clearly objective drawings in the literature the latebra is shown nearer one end of the long axis of the hen's ovum; they are v. Baer's Figs. I and 2, Plate III. (I 828) and Duval's Fig. 2I (I889). This observation can be made with certainty only on oöcytes during the final growth period or shortly after ovulation. Eggs taken subsequently show more or less diffusion between latebra and surrounding yolk so that accurate measurements are usually impossible (cf. my figures just mentioned). Purkinje made mention of this fact in 1825 . It will be remembered in this connection that the yolk increases in weight as it passes down the oviduct, taking up water from the surrounding albumen during its progess (cf. Curtis, I9II).

Since I was able to show that the position of the latebra nearer one end of the long axis is determined by the corresponding position of the germinal vesicle in earlier stages it is possible to trace the principal axis with one end morphologically different 
from the other, to the youngest oöcytes in the ovary. These facts have been confirmed by my subsequent observations and the complete demonstration for the pigeon requires only experimental evidence.

H. The Relation of the Embryo to the Principal Egg Axis (Axis Angle).-Who was the first to describe this remarkable relation? No one has ever tried to find out. Duval (I 884) has often been given credit for it, but he was only one of the few who have published concrete data on the subject. These data and the use he made of them are largely responsible for the deeply rooted tradition of today that the embryo in the hen's egg lies at right angles to the principal egg axis. It speaks volumes for the mighty influence which the classic "Atlas d'Embryologie" has had upon all of us. Duval himself gives the credit to Balfour and Kölliker as Kionka also does in I894, but neither of these appears to have mentioned the matter except incidentally in their text-books. Dareste (I89I) and Rabaud (I908) attribute it to v. Baer. v. Baer wrote one of the best and most complete accounts that has ever appeared in the 1828 edition of his epochmaking work. It is difficult to understand how this discussion has come to be so completely forgotten. But v. Baer himself speaks of the relation as a matter of common knowledge at the time. The earliest mention I have succeeded in finding is in Pander's thesis (I8I7). In the German edition illustrated by D'Alton which immediately followed the original he says (p. 9): "Sobald die Längenpole des Embryo, welche nicht dem Längensondern dem Querdurchmesser des Eyes entsprechen gesetzt sind, entsteht zwischen den beiden Falten (des Primitifstreifens) der Länge nach, ein zartes, oben rundlich, unten lanzettförmig breiter Streifen, das Rudiment des Rückenmarkes." The casual nature of the statement leads me to think that he was merely stating an accepted fact which was not particularly significant for the matter in hand. As many workers before the day of physiological salt solution opened the egg at the broad end by way of precaution it may not have been discovered much before this time.

It is possible that Malpighi (I672) noticed the variability between the principal egg axis and the embryonic axis. In all of his figures the embryo is drawn with the head $u p$ on the page and in most it is parallel to the sides of the page. In certain 
young ones however (Tab. I., Figs. 2, 3, 5, 6 and 7 and Tab. II $a$, Fig. I) the long axis of the embryo is inclined to the vertical. In all but one of these the angle is less than $90^{\circ}$. As it is probable that he drew all the younger blastoderms in situ on the yolk, it may be that they had been oriented with reference to the chief shell axis. I did not find any reference to this point in the text.

The relation is best summed up in the words of v. Baer (I828, p. I2):

"Lage des Embryo.-Um die vierzehnte oder fünfzehnte Stunde tritt das erste Rudiment des Embryo auf. Dieses besteht keinesweges in den beiden Primitivfalten Pander's, sondern in einem mittlern Streifen, der etwa I I $/ 2$ Linie lang ist, und den ich Primitivstreifen nenne. Er ist der Vorläufer der Wirbelsaule und liegt in der Längenachse des durchsichtigen Fruchthofes. Die Längenachse des Fruchthofes entspricht aber nicht der Längenachse des Eies, sondern der Querachse desselben, und zwar liegt der Kopf des zukünftigen Embryo, der in dem ersten dunklen Streifen schon durch ein etwas dickeres Ende angedeutet wird, nach links, das Schwanzende nach rechts, wenn man das $\mathrm{Ei}$ in seiner Längenachse so vor sich stellt dass das stumpfe Ende dem Beobachter zu- und das spitze Ende abgekehrt ist, der Keim aber nach oben liegt. Hiernach ist die linke Seite des Embryo nach dem stumpfen Ende des Eies gerichtet, die rechte nach dem spitzen Ende. Indessen ist diese Lage nicht immer so bestimmt, dass die Längenachse des Embryo mit der Längenachse des Eies genau einen rechten Winkel bildete, der Winkel weicht vielmehr so ab, dass die erstere bald auf der einen, bald auf der anderen Seite sich mehr der letztern nähert, so dass, freilich in sehr seltenen Fällen, beide Achsen fast zusammenfallen können, wobei dann der Kopf des Embryo bald dem stumpfen, bald dem spitzen Ende des Eies zugekehrt ist. Nur einmal fand ich den Embryo umgekehrt liegen, so dass sein Kopf in der Hälfte des Eies lag, in der das Schwanzende hätte liegen sollen."

The first writer who gave statistics on axis angles is Dalton (I88I). He made observations on Ioo hen's eggs holding the pointed end of the shell to the right and noting in which octant the head lay; in other words he grouped his observations in $45^{\circ}$ classes. I have transposed his data so that they may be directly compared with my own. 


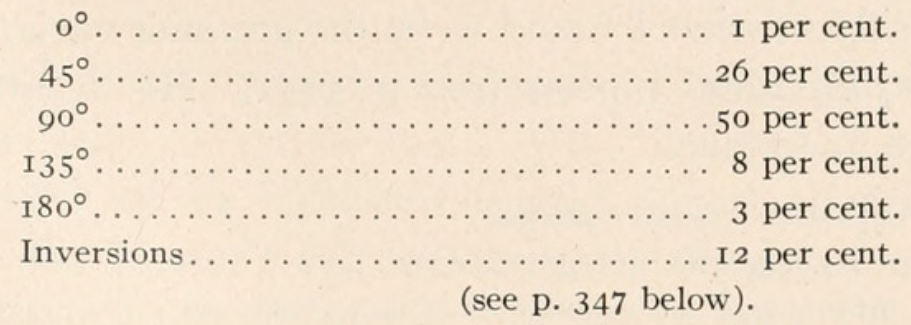

Dalton also took cognizance of the relation between the ovum and the embryo for he suggests that the position of the embryo on the yolk may be due to the way in which segmentation takes place in the "cicatricula"-referring to Kölliker's suggestion regarding the eccentricity of cleavage. He then remarks that variation in the relation of the embryo to the shell may be due to the manner in which the yolk is received and transported through the oviduct. He at least, had not failed to read v. Baer.

Duval (I884) who does not seem to have ever seen "Ueber die. Entwickelungsgeschichte der Thiere" and who speaks of "la loi énoncée par Balfour," was the first to make practical use of the axis angle. He saw that it afforded a means of orienting stages previous to the appearance of the primitive streak and accordingly made a "petite statistique" upon I66 hen's eggs incubated 39 hours. He observed the angle between embryo and shell and to judge from his diagrams grouped them in the following classes:

$\begin{array}{rrrr}90^{\circ} & \text { I } 24 \text { eggs } & 76 \text { per cent. } \\ \text { circa } 65^{\circ} & \text { I3 “ } & 8 \text { per cent. } \\ \text { circa } 110^{\circ} & 26 “ & \text { I } 6 \text { per cent. } \\ 180^{\circ} & 2 \text { “ } & \text { I per cent. } \\ \text { (Inversion) } 270^{\circ} & \text { I egg } & \text {. } 6 \text { per cent. }\end{array}$

The large number of cases at or very near $90^{\circ}$ may be due partly to the personal equation for which there are many loopholes in his method of measurement, partly perhaps to his having obtained his eggs from a small flock of hens.

Féré (1900) published the most extensive data that have appeared on the hen's egg, in connection with his demonstration that such experimental eggs as develop normal embryos have no more variation in the axis angles than the controls do. His results are tabulated as percentages of "deviations." He considers all cases which show a variation of $45^{\circ}$ or more from the "norm," as "deviations." Expressed in my terms this means there is a normal variation of $90^{\circ}$, from 45 to $\mathrm{I} 35^{\circ}$ which corre- 
sponds exactly to what I found to be the greatest variation in the eggs of an individual pigeon (see p. 347). His results may be summarized as follows:

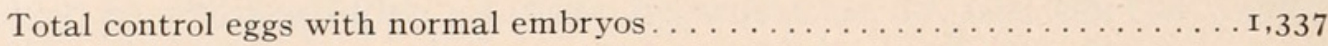

Total experimental eggs with normal embryos . . . . . . . . . . 588 Percentage of normal eggs with deviation of more than $45^{\circ} \ldots \ldots 2$ I.39 per cent. Percentage of experimental eggs with deviation of more than $45^{\circ} \ldots 28.82$ per cent.

In 1908 Rabaud published an exceedingly interesting study upon variation of axis angles in the hen's egg. He determined first from a series of I05 eggs taken at random that as much variation might be met with normally as was reported by Féré, Blanc, and Ferret et Weber in their experimental series. This is shown in the following tabulation of his results:

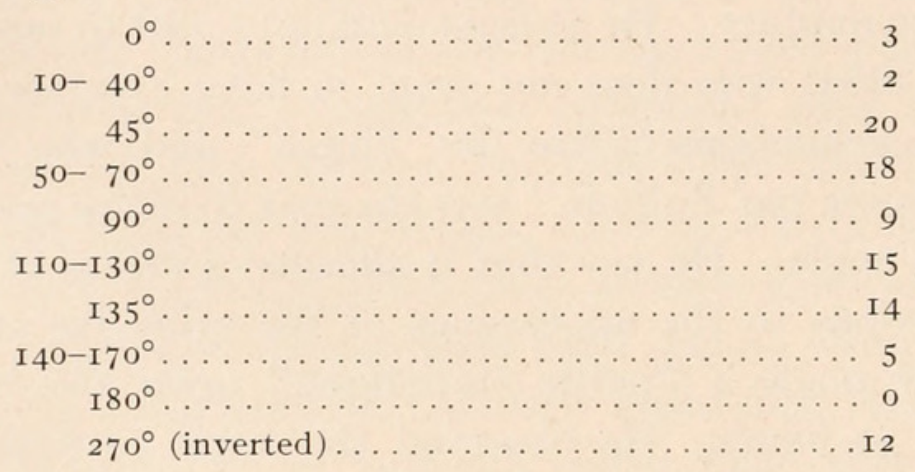

Rabaud showed also by a series of observations on over Ioo eggs with windows in the shell that in the course of the first five or six days' incubation the axis angle does not change.

For the pigeon Patterson (I909) gives the usual axis angle as $45^{\circ}$ (see my I9I2 paper, p. 300), whereas Blount (I909) mentions variations such as $60^{\circ}$ and $150^{\circ}$, but regards these as "comparatively rare." My own results which showed much greater variability for the pigeon's eggs and indicated less variability for the eggs of a given bird are discussed on page 347 below.

The only other reports on the relation of embryo to egg in birds are those of Haswell (I887) for the emu and Féré (I 896) for the duck. The former found all the relations described by v. Baer for the hen's egg. The embryo was "usually at right angles" but "not infrequently oblique though never longitudinal" to the principal egg axis. Féré (I 896) compared the axis angles in the duck with the hen and found they agreed except that the duck showed greater variability. In a series of 74 eggs of each kind, 75 per cent. of the duck eggs showed a 
"deviation" of $45^{\circ}$ or more as compared with 30 per cent. of the hen's eggs.

In a clutch of six sparrows' eggs I found all the relations typical of the pigeon's egg including the long axis of the yolk and the ligamentum albumenis. In two of these the axis angle could be measured and was found to be $45^{\circ}$ in one, and about I $25^{\circ}$ in the other.

\section{Axis Angles.}

Before considering the relations found in the eggs of the individual birds it is necessary to consider the normal range of variability in the pigeon's egg. The curve, Fig. 2, shows that the variability is great, in fact, one may meet with almost any angle from $o$ to $\mathrm{I} 80$ degrees. The extremes met with were 3 and $\mathrm{I} 80^{\circ}$ both of them in eggs which had abnormal chalazæ and were therefore not included in the curve. The latter is unique as there were no cases found between $135^{\circ}$ and $\mathrm{I} 80^{\circ}$. All similar cases in which the absence of well marked long and chalazal axes made it impossible to measure the angle accurately were omitted, thus eliminating about 7 per cent. of the eggs studied. As is indicated in the curve, the maximum variation was $127^{\circ}$ in normal eggs; there were two cases at I 35 and one at $8^{\circ}$, all three of them perfectly normal typical eggs in other respects.

The curve of axis angle variability which I published previously (p. 303) shows four modes. These seemed to indicate that a flock of birds could be divided into groups laying eggs with similar angles. In plotting the present more extensive data the curve (Fig. 2) has been compressed by making Io instead of 5 degree classes and it suggests another interpretation. It shows a resemblance to a curve of normal variability with its mode at $70^{\circ}$ and were there several thousand instead of a trifle over five hundred cases I believe the resemblance would be much more striking. It suggests in other words that the actual angle between embryo and principal axis is a matter of chance. It should be noted that 85 per cent. of all cases lie between 45 and $90^{\circ}$. This means that in the pigeon egg the right side of the embryo is practically always (98 per cent.) directed toward the pointed end of the shell, but that in addition the head is usually inclined in the same direction. Obviously Patterson (I9I0) was correct as to the essential relation between the pigeon embryo 
and the chalazal axis but the axis angle is usually greater than he believed. We cannot be more specific concerning the axis angle in the pigeon than to say that in the great majority of eggs

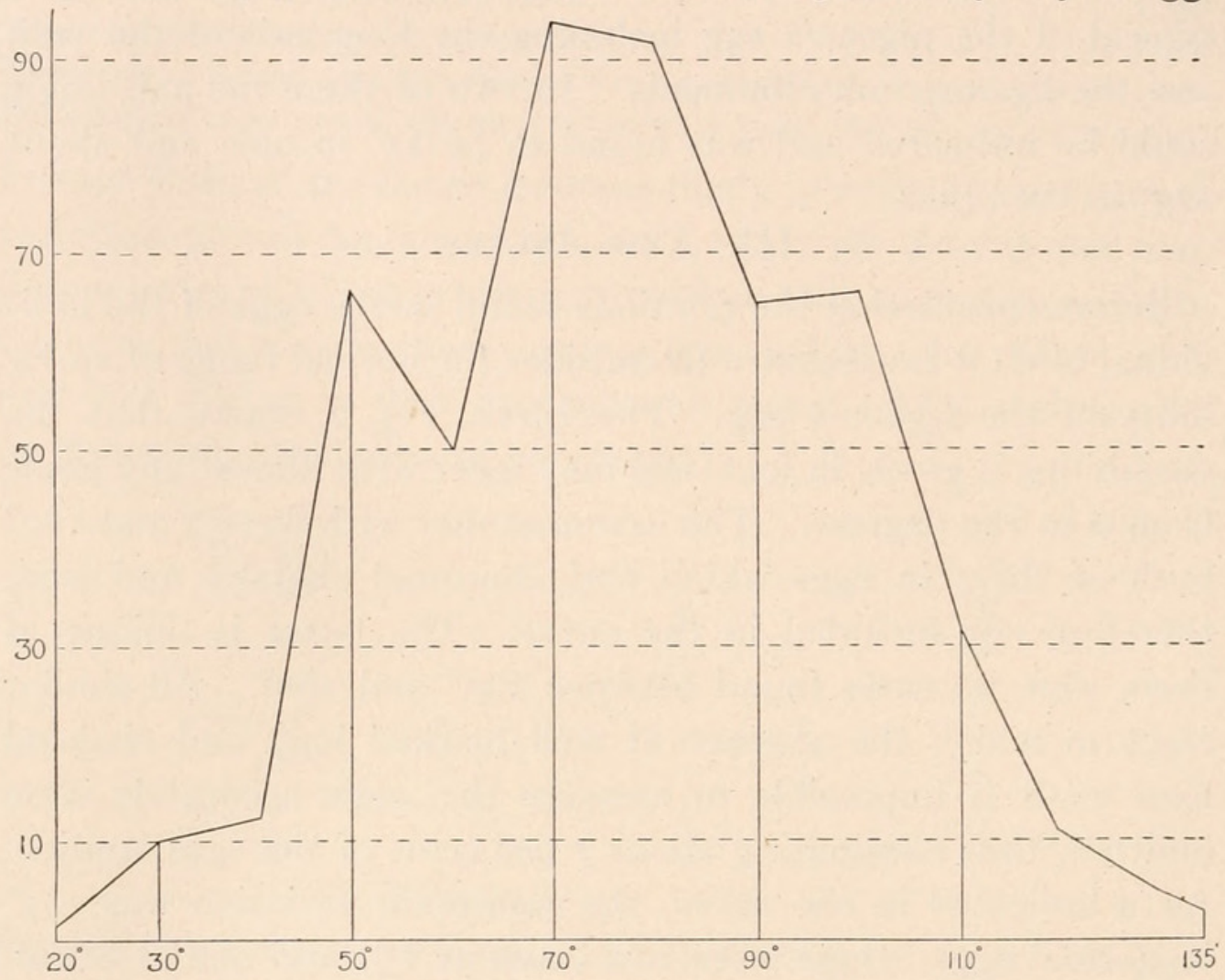

FIG. 2. Curve of variability in axis angles plotted from observations on 506 eggs from 90 different birds. The angles could be measured accurately to $5^{\circ}$. The eggs were grouped in $10^{\circ}$ classes and the number of cases in each class plotted as ordinates, the angles as abscissæ. The resemblance to a symmetrical curve of normal variability is apparent.

the head of the embryo lies in the second octant of the (animal) polar hemisphere.

\section{The Axis Angles of Individual Birds.}

My previously published data indicated that the eggs of a given bird show less variation in axis angles than do the eggs of different birds. The following birds were studied for four years, certain of their young mated and their eggs likewise observed. All the birds were the mongrel "homers" of the dealers. The original pairs were given me by Professor Whitman in I9Io. They had the freedom of a large attic room where they were free from disturbance, could choose their mates, build their nests and keep comparatively happy throughout the year. At the time I thought there might be some relation between sex 
and axis angle variation so in view of Professor Whitman's results the layings were not forced (see Riddle, I9I4). When the eggs were removed dummies were left in their places for about two weeks until the birds recognized the deceit or the futility of further incubation and made preparations for another laying. From time to time each pair was permitted to hatch and rear young. Under these conditions the average number of clutches per year was I6, a figure which has been considerably lowered by inclusion of the records of the old birds at the end of their active laying period. The spring was the most prolific season, the autumn the least so, as Pearl and Surface (I9I I) observed for the hen.

The angles were measured as described in I9I2. As some pigeon eggs show little difference between the two ends of the shell the position of the air space was always noted; its end of the shell is readily seen when the egg is placed in the salt solution since it floats up higher than the other. The blunt or air space end of the shell was held to the left, the other end removed with forceps and the contents drawn out. Thus any possible confusion between the two chalazæ was avoided. Except during the first year the eggs were left under the birds for two to three and one half days. As pigeons are usually very lax about incubating until the second egg has been laid the embryos varied from the five to the twenty somite stages. During this period the embryonic axis can be accurately observed and there is normally not enough yolk digestion or absorption of albumen to interfere with the identification of the long axis of the yolk.

Pigeon No. 3.- This was an old bird at the outset to judge from her subsequent activity. The first egg was laid March I6, I9I0, the last January I4, I9I2; ten weeks later she was killed and a normal resting ovary found. During these 22 months she laid 29 clutches without a single abnormal or infertile egg.

TAble J. (Pigeon No. 3.)

\begin{tabular}{|c|c|c|c|c|c|c|c|c|}
\hline Year. & $\begin{array}{l}\text { Normal } \\
\text { Eggs. }\end{array}$ & $\begin{array}{l}\text { Inver- } \\
\text { sions. }\end{array}$ & $\begin{array}{l}\text { Only } \\
\text { One } \\
\text { Egg in } \\
\text { Clutch. }\end{array}$ & $\begin{array}{c}\text { Infertile } \\
\text { Eggs. }\end{array}$ & $\begin{array}{c}\text { Abnor- } \\
\text { mal Em- } \\
\text { bryo. }\end{array}$ & $\begin{array}{l}\text { Eggs } \\
\text { Incu- } \\
\text { bated. }\end{array}$ & $\begin{array}{l}\text { Eggs } \\
\text { Lost. }\end{array}$ & Totals. \\
\hline I $\ldots \ldots \ldots \ldots$ & 25 & o & 0 & o & o & IO & I & 36 \\
\hline II $\ldots \ldots \ldots \ldots$ & $2 \mathrm{I}$ & o & I & o & o & 2 & o & 23 \\
\hline $\begin{array}{l}\text { Entire period of ac- } \\
\text { tivity I yr. Io mos.. }\end{array}$ & 46 & 0 & I & 0 & 0 & I 2 & I & 59 \\
\hline
\end{tabular}


All of the twelve eggs that were incubated to hatching produced normal young.

The only irregularity during almost two years was the laying of one clutch with a single egg. This is usually due to the failure of the first or second egg to enter the oviduct at ovulation or to its escape soon after. More rarely only a single ovum matures at a time.

The range of variability (Fig. 3,3 ) is striking as it ranges from 90 to I 30 degrees, whereas it is uncommon in the pigeon to find the angle greater than 90 degrees. The actual variability is small, and while this might be attributed to the small number of cases I am inclined to think the small number of extreme variants is to be correllated with the exceptionally well marked long axis and the uniformly normal chalazæ. Clutch 395 may serve as an example of the size relations of the axes of the ovum:

First egg (primitive streak embryo) $21.8 \mathrm{~mm}$. (long axis), $19.5 \mathrm{~mm}$. (transverse axis), $18.0 \mathrm{~mm}$. (polar axis).

Second egg (Io somites) $20.7 \mathrm{~mm}$. (long axis), I7.6 mm. (transverse axis), I8.0 mm. (polar axis).

We have in this case then a clue to the amount of variability which we must expect in eggs of a single bird where the ovum is normal and there are no irregularities in the functioning of the oviduct. That is to say, in this case the variations due to imperfect orientation in the oviduct and errors of observation due to abnormal chalazæ have been practically eliminated.

Pigeon No. 4.- This bird and her mate had recently paired when first observed. The first egg was laid January 4, I9I0. After sixteen clutches had been laid during thirteen months the male was killed by a Diener. Two months later no. 4 mated again and continued laying for the'next three years. A similar experiment was made purposely with no. 6 in order to see whether any difference could be observed between the eggs laid during the two matings. During the next two years no. 4 laid 29 clutches; and six during her last year; none of these last could have hatched as the table shows. She was killed March 2I, I9I4, when an abnormal egg was found in the "uterus," although ovary and oviduct appeared normal. The abnormality in the last year may have been due to the sperm although the male was apparantly normal and younger than his mate. 
Table II. (Pigeon No. 4.)

\begin{tabular}{|c|c|c|c|c|c|c|c|c|}
\hline Year. & $\begin{array}{c}\text { Normal } \\
\text { Eggs. }\end{array}$ & $\begin{array}{l}\text { Inver- } \\
\text { sions. }\end{array}$ & $\begin{array}{c}\text { Only One } \\
\text { Egg in } \\
\text { Clutch. }\end{array}$ & $\begin{array}{c}\text { Infertile } \\
\text { Eggs. }\end{array}$ & $\begin{array}{l}\text { Abnormal } \\
\text { Embryo. }\end{array}$ & $\begin{array}{c}\text { Incubated } \\
\text { Eggs. }\end{array}$ & $\begin{array}{l}\text { Eggs } \\
\text { Lost. }\end{array}$ & Totals. \\
\hline $\begin{array}{l}\text { I } \ldots \ldots \\
\text { II } \ldots \ldots \\
\text { III } \ldots \ldots \\
\text { IV } \ldots \ldots\end{array}$ & $\begin{array}{r}27 \\
\text { I } 5 \\
27 \\
0\end{array}$ & $\begin{array}{l}0 \\
\text { I } \\
\text { I } \\
\text { o }\end{array}$ & $\begin{array}{l}\mathrm{I} \\
2 \\
4 \\
\mathrm{I}\end{array}$ & $\begin{array}{l}\mathrm{I} \\
2 \\
\mathrm{I} \\
4\end{array}$ & $\begin{array}{l}2 \\
0 \\
3 \\
\mathrm{I}\end{array}$ & $\begin{array}{l}2 \\
8 \\
3 \\
0\end{array}$ & $\begin{array}{l}\text { I } \\
2 \\
0 \\
0\end{array}$ & $\begin{array}{r}32 \\
27 \\
29 \\
6\end{array}$ \\
\hline 4 years .. & 69 & 2 & 8 & 8 & 6 & I3 & 3 & 94 \\
\hline
\end{tabular}

This record doubtless includes the bird's entire period of activity. The falling off during the second year was due to the period between matings (the active months of February and March) and the hatching of four clutches later in the spring. As it was she laid 5 I clutches in the course of four years; I2 per cent. of the eggs were abnormal but most of these latter were laid during the last year.

The curve of variability (Fig. 3,4 ), has a single mode when $10^{\circ}$ classes are used but with five degree classes there is one mode at $70^{\circ}$ another at $85^{\circ}$. There is a total variation of $53^{\circ}$ from $5^{2}$ to $105^{\circ}$. 72 per cent. of the eggs measured fall between 65 and $85^{\circ}$. Of the twelve eggs which diverged most widely from the mean 9 showed irregularities in the chalazæ, the others were quite typical. One egg which showed an angle of $35^{\circ}$, twenty degrees lower than any other egg of this bird, was not included in the data plotted, as the long axis was obliterated by yolk digestion. Another egg which showed no well defined long axis had an angle near the other extreme of variation, namely $95^{\circ}$. The long axis was distinct in all the other eggs of no. 4, as may be seen from two examples:

Egg 399 (I I somites) 2I mm. (long axis), $19.0 \mathrm{~mm}$. (transverse axis), $19.0 \mathrm{~mm}$. (polar axis).

Egg 479 (primitive streak) $22.0 \mathrm{~mm}$., $19.4 \mathrm{~mm}$. (transverse axis), $18.0 \mathrm{~mm}$. (polar axis).

Two curves plotted from the eggs laid during the first and second matings are almost identical and so this case affords no evidence that the male has any effect upon the relation of embryo to principal egg axis.

The records of the remaining three pairs are more complete as they were the offspring of the above pairs. Their relationships are as follows: 

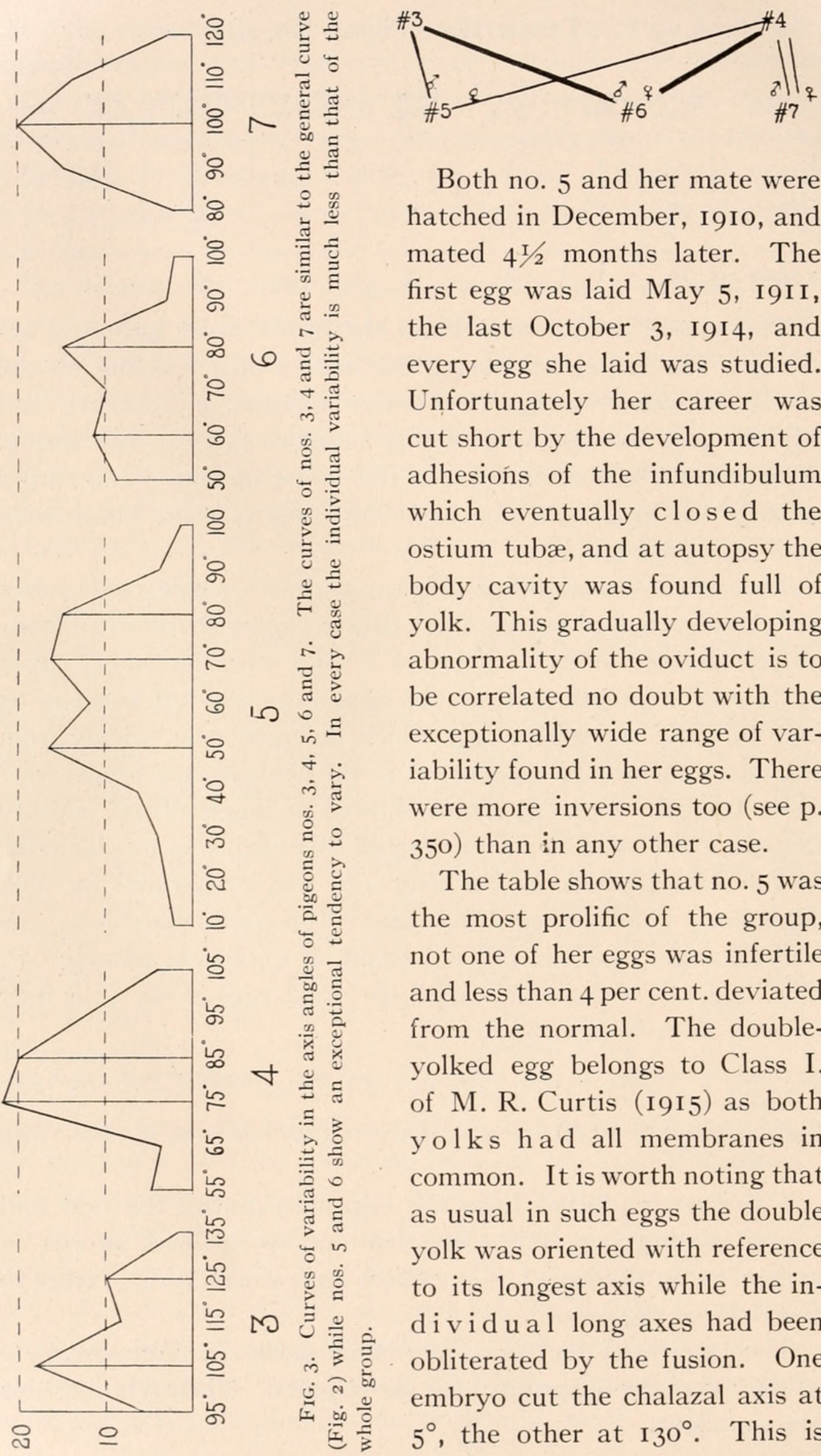

Both no. 5 and her mate were hatched in December, I9Io, and mated $4 \frac{1}{2}$ months later. The first egg was laid May 5, I9II, the last October 3, I9I4, and every egg she laid was studied. Unfortunately her career was cut short by the development of adhesions of the infundibulum which eventually closed the ostium tubæ, and at autopsy the body cavity was found full of yolk. This gradually developing abnormality of the oviduct is to be correlated no doubt with the exceptionally wide range of variability found in her eggs. There were more inversions too (see p. $350)$ than in any other case.

The table shows that no. 5 was the most prolific of the group, not one of her eggs was infertile and less than 4 per cent. deviated from the normal. The doubleyolked egg belongs to Class I. of M. R. Curtis (1915) as both yolks had all membranes in common. It is worth noting that as usual in such eggs the double yolk was oriented with reference to its longest axis while the individual long axes had been obliterated by the fusion. One embryo cut the chalazal axis at $5^{\circ}$, the other at $130^{\circ}$. This is 
Table III. (Pigeon No. 5.)

\begin{tabular}{|c|c|c|c|c|c|c|c|c|}
\hline Year. & $\begin{array}{c}\text { Normal } \\
\text { Eggs. }\end{array}$ & $\begin{array}{l}\text { Inver- } \\
\text { sions. }\end{array}$ & $\begin{array}{l}\text { Only } \\
\text { One } \\
\text { Egg in } \\
\text { Clutch. }\end{array}$ & $\begin{array}{c}\text { Infertile } \\
\text { Eggs. }\end{array}$ & $\begin{array}{c}\text { Abnormal } \\
\text { Eggs. }\end{array}$ & $\begin{array}{l}\text { Eggs } \\
\text { Incu- } \\
\text { bated. }\end{array}$ & $\begin{array}{l}\text { Eggs } \\
\text { Lost. }\end{array}$ & Totals. \\
\hline I. & 32 & o & 2 & o & I & 5 & 5 & 42 \\
\hline II $\ldots \ldots \ldots \ldots$ & 29 & 2 & o & 0 & $\begin{array}{l}\text { I (double- } \\
\text { yolked egg) }\end{array}$ & 4 & 0 & 32 \\
\hline \multirow{2}{*}{$\begin{array}{l}\text { Last five } \\
\text { months...... }\end{array}$} & I9 & 3 & I & o & 2 & 3 & I & $2 \mathrm{I}$ \\
\hline & 7 & I & I & 0 & 0 & 0 & o & 7 \\
\hline 3 yrs. 5 mos... & 87 & 6 & 4 & 0 & 4 & I 2 & 6 & 102 \\
\hline
\end{tabular}

further evidence that extremes of variation in the axis angles are due to the failure of an ovum to orient itself in the oviduct with reference to its long axis. The nine extreme variants of this bird showed irregularities in the development of the chalazæ or other abnormalities. The long axis was well marked in all but three eggs. Clutch $6 \mathrm{I} I$ is typical;

First egg (7 somites ) $21.3 \mathrm{~mm}$. (long axis) $19.5 \mathrm{~mm}$. (transverse axis), I9.0 mm. (polar axis).

Second egg (4 somites) 2 I.0 mm. (long axis) $19.8 \mathrm{~mm}$. (transverse axis), I8.0 $\mathrm{mm}$. (polar axis).

Although only three of this bird's eggs had abnormal embryos and all twelve eggs that were incubated hatched, yet her eggs showed the greatest variability (Fig. 3, 5), a fact which, as has been said, is to be correlated with the abnormal oviduct. One extreme observed was $5^{\circ}$, this was a very abnormal egg as the chalazæ were not attached to the yolk at all but to the outside of the dense albumen. The greatest variation was $84^{\circ}$ among the normal eggs.

Pigeon No. 6.- This bird was hatched January 30, I9I I, but did not mate until eight months later. The first egg was laid October 29, I9II. Since there were 7 infertile eggs in the next I 3 clutches, the male was killed and five months later she mated again with the bird indicated on page 343 . In the following two years and two months 24 clutches were laid. The observations had to be discontinued before she ceased to lay, but as she was four years old at the time and had begun to lay numerous abnormal and infertile eggs this record represents practically all her reproductive activity. The high percentage of infertile eggs during the first year was undoubtedly due to her first mate; nevertheless her layings were very irregular and could never be predicted. The curve (Fig. 3, 6 ) shows that the axis angles varied 
TABle IV. (Pigeon No. 6.)

\begin{tabular}{|c|c|c|c|c|c|c|c|c|}
\hline Year. & $\begin{array}{c}\text { Normal } \\
\text { Eggs. }\end{array}$ & $\begin{array}{l}\text { Inver- } \\
\text { sions. }\end{array}$ & $\begin{array}{c}\text { But One } \\
\text { Egg in } \\
\text { Clutch. }\end{array}$ & $\begin{array}{c}\text { Infertile } \\
\text { Eggs. }\end{array}$ & $\begin{array}{c}\text { Abnormal } \\
\text { Eggs. }\end{array}$ & $\begin{array}{l}\text { Incu- } \\
\text { bated } \\
\text { Eggs. }\end{array}$ & $\begin{array}{l}\text { Eggs } \\
\text { Lost. }\end{array}$ & Totals. \\
\hline $\begin{array}{l}\text { I } \ldots \ldots \cdots \\
\text { II } \ldots \ldots \cdots \cdots \\
\text { III } \ldots \ldots \ldots\end{array}$ & $\begin{array}{l}22 \\
\text { I } 2 \\
2 \mathrm{I}\end{array}$ & $\begin{array}{l}0 \\
0 \\
0\end{array}$ & $\begin{array}{l}0 \\
I \\
2\end{array}$ & $\begin{array}{l}7 \\
2 \\
4\end{array}$ & $\begin{array}{c}0 \\
0 \\
3 \text { (one was } \\
\text { yolkless) }\end{array}$ & $\begin{array}{l}0 \\
8 \\
\text { I }\end{array}$ & $\begin{array}{l}I \\
0 \\
2\end{array}$ & $\begin{array}{l}30 \\
19 \\
30\end{array}$ \\
\hline 3 years 5 mos. & 53 & 0 & 3 & I3 & 3 & 9 & 3 & 79 \\
\hline
\end{tabular}

in a typical manner, the extremes in normal eggs being $43^{\circ}$ and $98^{\circ}$. The most extreme variations were here clearly due to imperfect orientation in the oviduct. Thus two eggs which had no long axis showed angles of $105^{\circ}$ and $180^{\circ}$ respectively. Most of her eggs had a well-defined long axis; e. g., no. 497, 21.9 mm. (long axis), I $8.0 \mathrm{~mm}$. (transverse axis), $17.5 \mathrm{~mm}$. (polar axis). There was no difference to be found in the angles of the eggs laid during the first and second matings.

Pigeon No. 7.- The egg from which this bird was hatched was laid only five days after the last egg of the previous clutch. As it is very rare for a pigeon to lay a second clutch in less than eight days after a first, it seemed possible that the egg might have been laid in no. 4's nest by another bird. However all the active females in the flock had laid within seven days of this date so it seems unnecessary to speculate on the possibility of the parent birds having failed to guard their nest long enough for another bird to lay in it. No. 7 was hatched April 20, I9I2, her mate the middle of the following August and they mated in November. The first egg was laid December 2, I9I2. The 34 clutches laid during the following two and a quarter years when the work was stopped do not nearly represent the whole active period of this bird.

Table V. (Pigeon No. 7.)

\begin{tabular}{|c|c|c|c|c|c|c|c|c|}
\hline Year. & $\begin{array}{l}\text { Normal } \\
\text { Eggs. }\end{array}$ & $\begin{array}{l}\text { Inver- } \\
\text { sions. }\end{array}$ & $\begin{array}{l}\text { But One } \\
\text { Egg in } \\
\text { Clutch. }\end{array}$ & $\begin{array}{c}\text { Infertile } \\
\text { Eggs. }\end{array}$ & Abnormal Eggs. & $\begin{array}{l}\text { Incu- } \\
\text { bated } \\
\text { Eggs. }\end{array}$ & $\begin{array}{l}\text { Eggs } \\
\text { Lost. }\end{array}$ & $\begin{array}{l}\text { Totals } \\
\text { for } \\
\text { Year. }\end{array}$ \\
\hline $\begin{array}{l}\text { I } \ldots \ldots \ldots \\
\text { II } \ldots \ldots \ldots \\
\text { Last three } \\
\text { months. . . }\end{array}$ & $\begin{array}{l}20 \\
26\end{array}$ & $\begin{array}{l}0 \\
0\end{array}$ & $\begin{array}{l}0 \\
0\end{array}$ & $\begin{array}{l}\text { I } \\
\text { I }\end{array}$ & $\begin{array}{c}\text { I } \\
\text { I (double- } \\
\text { yolked egg) } \\
\text { I }\end{array}$ & $\begin{array}{l}2 \\
5\end{array}$ & $\begin{array}{l}2 \\
\mathrm{I}\end{array}$ & $\begin{array}{l}26 \\
32\end{array}$ \\
\hline 2 yrs. 3 mos.. & 56 & o & 0 & 2 & 3 & 7 & 3 & 68 \\
\hline
\end{tabular}


The table shows few peculiarities. The range of variability was low (from 75 to $\operatorname{II} 7^{\circ}$ ). There were five eggs which had no well-marked long axis; three of them had extreme angles $\left(70^{\circ}\right.$, II $7^{\circ}$ and $\left.124^{\circ}\right)$, the other two from a single clutch, were $95^{\circ}$ and $96^{\circ}$. In this case (clutch 629) the ova measured as follows:

First egg $2 \mathrm{I} .2 \mathrm{~mm}$. (chalazal axis) $2 \mathrm{I} .2 \mathrm{~mm}$. (transverse axis) $\mathrm{I} 9.3 \mathrm{~mm}$. (polar axis). Second egg $19.2 \mathrm{~mm}$. (chalazal axis) $19.0 \mathrm{~mm}$. (transverse axis) $19.0 \mathrm{~mm}$. (polar axis).

\section{Discussion.}

A. Variability of the Axis Angles.-The data presented here are the most complete that have been gathered with reference to the axis angles of any bird's egg and they show that while the actual angle may vary considerably, the relation between the head of the embryo and the principal egg axis is very constant. What I have called "inversions" (see p. 349) occur in less than I per cent. of the cases. The embryo may lie in almost any position compatible with the general relation between the two axes. If we omit eggs that were not normal as to embryo or chalazæ (circ. Io per cent. of all), and include only those which could be measured accurately, the extreme axis angles are 8 and $\mathrm{I} 35^{\circ}$. If we compare this maximum with the maximum found for any single bird, namely, $127^{\circ}$ as compared with $86^{\circ}$, it is obvious that a given bird's eggs will show less variability than the eggs from a flock. The difference between the two is not fully appreciated until we realize that the maximum variability in the other four birds of the group studied was 40,42 , 53 and $55^{\circ}$ respectively; the average maximum variability then for a single bird's eggs is about two thirds of the total variability observed. We may predict that a given pigeon's eggs will show the embryo lying in a quadrant the center of which is usually between 45 and $95^{\circ}$ according to the particular bird. In other words the embryonic axis will cut the principal egg axis at an angle which may vary $25^{\circ}$ on either side of a mean. The variation we find in an individual bird's eggs makes it clear that the axis angle is no mathematically constant one like the angles of a crystal. There are various mechanical factors operating during ovarian and oviducal stages which undoubtedly contribute to the variability of the axis angle. Thus it is easy to see how 
during the growth of the oöcyte the original long axis might be changed more or less, particularly during the final rapid growth period. The oöcyte is free to rotate within its follicle at this time and if it cannot hang down into the body cavity so that attached and animal poles coincide exactly, the long axis of the follicle may not coincide with the original long axis of the ovum. At this time the embryonic axis is already established and so the original relation between long and embryonic axes may be changed (cf. Bartelmez, I9I2, p. 288).

The fact that all the most extreme variations were found in eggs with irregular chalazæ or poorly defined long axes makes it certain that difficulties of orientation in the oviduct at ovulation are important factors in axis angle variability. Further, if the chalazæ are not normally attached it is impossible to make accurate measurements. Eleven out of sixteen eggs which had no long axis or very irregular chalazæ were extreme variants for the bird that laid them. It is of course obvious that these factors may partly neutralize each other. This will not explain all the variations observed. We must assume a certain amount of spontaneous variability in the eggs of an ovary.

The first compilations seemed to show that there are always two modes in the curve of individual variation. These appear in Fig. 3, 3, 5 and 6 , and the same grouping about two modes can also be seen in the case of the eggs of no. 4. It was natural to expect that this might be correlated with the heterozygous nature of the bird's egg (see Riddle, I9I2, I9I4). That is to say, the larger, female-producing, eggs might vary about one mean, the smaller, male-producing, eggs about the other. The data from the 58 young hatched in the course of the study gave no evidence that the first egg was more frequently male-producing and Dr. Riddle tells me that this condition is found only in pure races of pigeons. Since also the size and weight of incubated yolks varies greatly from the absorption of albumen this possibility could not be tested out.

It is however a matter of great practical importance to see what the chances are that the first and second eggs will have about the same angles. In collecting early stages we usually determine the stage of the second egg from the time of laying of 
the first and so the first is available for a measurement of the axis angle. The following table shows the results.

\begin{tabular}{|c|c|}
\hline $\begin{array}{c}\text { Normal Range of } \\
\text { Variability. }\end{array}$ & $\begin{array}{l}\text { Percentage of Clutches in which } \\
\text { Both Eggs have the Same } \\
\text { Axis Angle. }\end{array}$ \\
\hline No. $3,40^{\circ}$ (from 90 to $\left.130^{\circ}\right)$ & $\ldots \ldots 45$ per cent. \\
\hline No. $4,53^{\circ}$ (from 52 to $\left.105^{\circ}\right)$ & $\ldots \ldots 46$ per cent. \\
\hline No. $5,84^{\circ}$ (from 8 to $92^{\circ}$ ). & .30 per cent. \\
\hline No. $6,55^{\circ}$ (from 43 to $\left.98^{\circ}\right)$. & .45 per cent. \\
\hline No. $7,42^{\circ}$ (from 75 to $\left.\operatorname{II} 7^{\circ}\right)$ & $\ldots 5^{6}$ per cent. \\
\hline
\end{tabular}

The average of these is 43 per cent. of coincidence, but if the very irregular no. 5 be omitted it is $5^{8}$ per cent.

It should be said further that there is no evidence that the eggs of a mother and daughter tend to resemble each other as to axis angles nor that there is any noticeable difference in the eggs of a bird during a first and second mating or during the early or later parts of her laying period.

We may say in conclusion that two sets of factors contribute toward extreme variation; irregularities in the laying down of the yolk during the final rapid growth period and irregularities in the functioning of the oviduct during the passage of the ovum. Aside from this we must expect normal spontaneous variation to the extent of at least 20 degrees on either side of a mean. This estimate of $40^{\circ}$ as the probable maximum spontaneous variation is based upon the records of no. 3 the eggs of which showed no signs of ovarian or oviducal irregularities. Accordingly, if we wish to determine the embryonic axis at a stage when it is not clearly differentiated morphologically, we can distinguish the cephalic from the caudal end of blastodisc or blastoderm in 99 out of Ioo cases. The axis angle however, can only be approximated. If the utmost possible accuracy is desired it is necessary to first measure a series of clutches, approximate the mode, eliminate such birds as show great variability, and use this mean angle. It is not likely to be more than $20^{\circ}$ wrong in any given egg. Nevertheless, the possibility of even greater variation must be considered in the interpretation of the results.

B. Inversions.-By inversions I mean those instances in which the head of the embryo is directed toward the observer when the egg is held in the usual manner (Figs. I and 4). Von Baer, (I828, 
p. I2) as he was the first to discuss axis angles was the first to record an inversion. He observed only one and suggested that it might have resulted from the cracking of the shell before incubation. It is evident from this that he did not appreciate the fundamental nature of the relation between embryo and principal egg axis. Subsequent workers, perhaps on this hint of v. Baer's, have presented evidence that the axis angle may be changed by experimental means. Thus Blanc (I892), Féré (I897 and later), Ferret et Weber (1904) and others have reported not only an increase in the number of extreme variations but also an increase in the number of inversions after poisoning the embryo or after interference with the secondary envelopes. While it is possible that an injured embryo may grow irregularly and so change the original direction of its axis (Féré, I900) it is highly improbable that it could become inverted. Most of these workers have not adequately determined the normal range of variability of their material. As has been said, the variability may in certain cases be much greater in the hen than in the pigeon. Professor A. P. Mathews tells me that as a student he planned similar experiments but abandoned them when he realized the extent of the normal variation in the hen's egg.

It is interesting to note in this connection that the earlier editions of Foster and Balfour's text-book gave the relations here termed "inversions" as the normal ones for the hen. As Balfour wrote this section of the book it may have been based upon his own observations or it may have merely been an accidental error. Dalton (I88I) reported I2 hen's eggs inverted out of Ioo while Duval (I884) found only one among I66, Rabaud (1908) I 2 in 98 and the writer 33 in Ioo. For the pigeon on the other hand I reported (I9I2, p. 30I), four cases among over 600 observations by Drs. Blount, Patterson and myself. The present study has thrown some new light on the question.

Inversions are very rare in pigeon eggs. I have studied eggs from about 90 pigeons; while many of them came from the five birds mentioned above, between two and twenty have been obtained from each of the others. Among all these only two birds, no. 4 and no. 5 laid inverted eggs. No. 4 laid two among 94 , no. 5 six among I02 eggs. In pigeon no. 5 the axis angles was 
exceptionally variable. The other three birds laying an aggregate of 204 eggs had no inversions. This gives a clue to the reason for the great difference in the number of cases reported for the hen. We are again dealing with a matter of individual variation. It is manifest that we should exclude from our studies involving axis angles all birds which show a tendency to vary over $25^{\circ}$ from a mean.

How are we to interpret the phenomenon when it does occur? Is it due to an inversion of relations in the ovary or is it more or less accidental? It is always possible that a normal ovum may be unable to orient itself with reference to gravity before ovulation owing to pressure from neighboring ova, adhesions of the

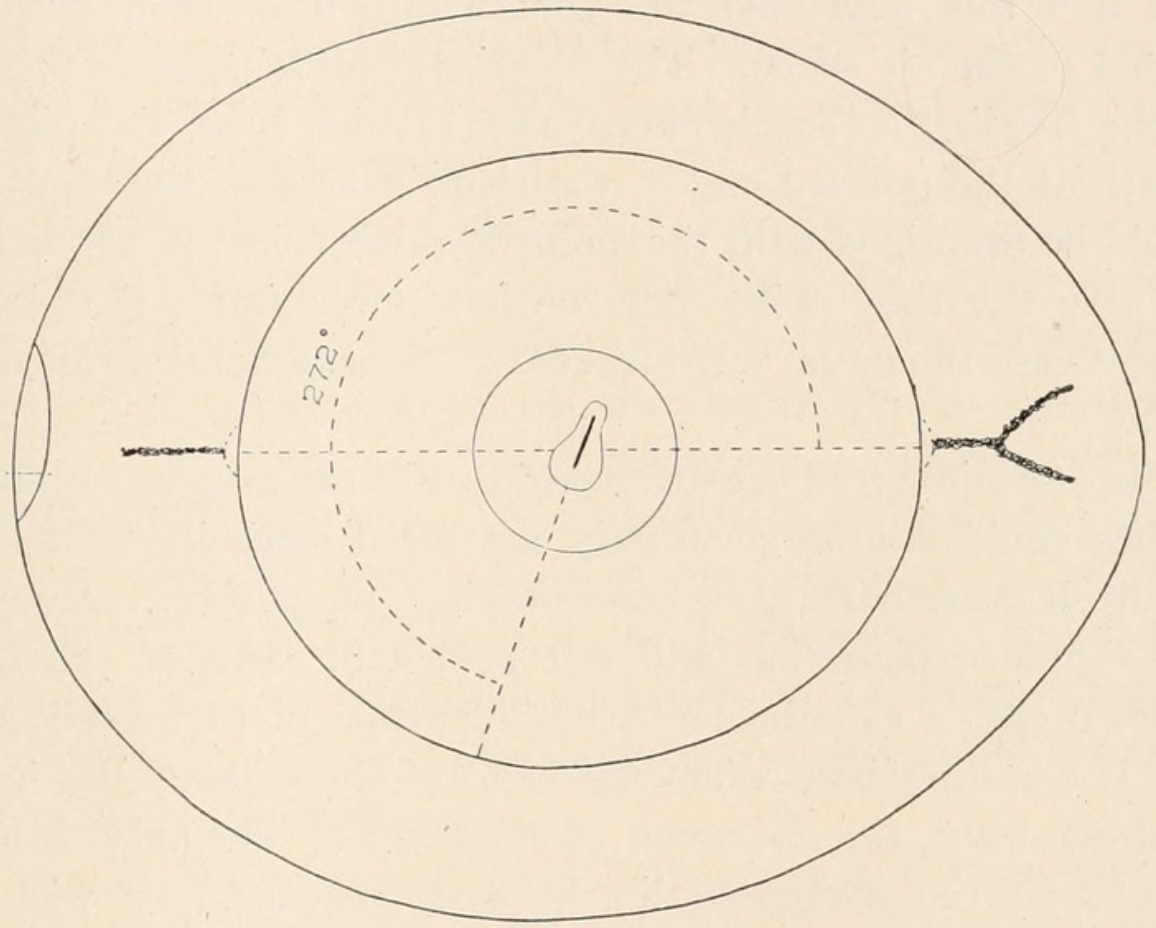

FIG. 4. A diagrammatic polar view of a pigeon's egg showing an "inverted" embryo. This type of inversion can be explained (egg $479^{\prime}$ of no. 4). In this particular case the inversion was very probably due to the fact that the end of the long axis of the yolk which should have entered the oviduct first, entered last.

oviduct, etc., and so the end of the long axis which should have entered first enters last. It may also have fallen in to the cœlom at first and have subsequently entered the duct inverted. Since we have complete records of no. 4 and no. 5 , the only birds I ever had which laid inverted eggs there is a basis for something more than speculation. When I opened egg $479^{\prime}$ of no. 4 and 
found the relations shown in Fig. 4 it was clear that if the egg were turned about the polar axis through $180^{\circ}$ we would have the usual axis angle for this bird, as 75 per cent. of her eggs had angles between 65 and $85^{\circ}$. Now if the normal orientation of the oöcyte had been accidentally inverted the latebra should be found nearer the cloacal chalaza than the other (vide p. 334 supra). It was poached, cut through the long and polar axes and the latebra was found I. $3 \mathrm{~mm}$. nearer the cloacal end of the long axis (toward the pointed end of shell) the reverse of the usual condition. It is always possible that the egg was not inverted until after it had entered the "uterus" but before the shell had been laid down (cf. Taschenberg, I 894, p. 308), but I am inclined to think that had this happened the yolk would have been normally related to the air space. The occasional birds' eggs as those of Corvus frugilegus (Taschenberg, I 894) which have the pigment wreath at the pointed end of the shell instead of the blunt end should be examined with this point in mind (vide, p. 332 supra). We may say then, with some degree of certainty, that in the present case the ovum was inverted at or near the time of ovulation.

The other inverted eggs were studied in the same way but the latebra could not be accurately measured since its boundaries usually become hazy even before laying (see p. 334). However this simple explanation will not suffice for any of the other inverted eggs I examined. A consideration of Fig. 4 will show that it can only hold when the head of the embryo lies in the third quadrant, i.e., between $\mathrm{I} 80$ and $270^{\circ}$. The axis angles of the other seven inversions lies between 285 and $325^{\circ}$ with the head therefore in the fourth quadrant. If, in these cases, we are to get the relations of embryo and long axis characteristic of the bird we must turn the ovum through $\mathrm{I} 80^{\circ}$ about the long axis and view the embryo from the vegetal pole as if the yolk were transparent. Obviously this means a reversal of polarity. There is a period in oögenesis when this might happen but I do not see how it could be demonstrated. At the beginning of my "period of differentiation" namely, (I9I2, p. 286), when the nucleus is nearer the center of the oöcyte than at any other time, it is possible especially in oöcytes with the animal pole nearer the 
periphery of the ovary, that the yolk might be so laid down that the nucleus would approach the original vegetal instead of the animal pole. Thus inversion would be accomplished. It should be noted also that three of the inverted eggs of no. 5 were the first eggs of three successive clutches and a fourth was laid soon after, all of them dating from the last six months before the ostium was closed by adhesions.

It is clear from these data that inversions are exceedingly rare in pigeons' eggs, and that only certain individuals ever lay such eggs. There are two types: those which are due to an inversion of the long axis of the ovum at ovulation and those which may be explained by assuming an inversion of the polarity of the oöcyte. It might be expected in such a case that one should find situs inversus viserum but this was not noted in the one instance in which the embryo was far enough developed to reveal it (cf. Conklin, I903).

C. Variations in the Chalaze. - The most accurate and convenient method of measuring the axis angle in an egg is to determine the relation between the chalazal and embryonic axes. Patterson (I909) was, I believe, the first to use the chalazæ for this purpose and I found it by far the most satisfactory method. It is important therefore, to see exactly how variable the chalazæ are and especially how frequently the chalazal axis deviates from the long axis of the ovum which determined it as well as other characters of the principal egg axis. A similar series of observations should be made on the hen's egg where there seems to be much more irregularity.

Typically one finds the chalazæ attached to the chalaziferous albumen at the ends of the long axis of the ovum. As the animal pole flattens out more and more during incubation the points of attachment seem to approach the animal pole, still remaining in the greatest circle of the elliptical ovum. It is rare to find this condition in the pigeon during the first two days of incubation. One often finds a cap or button of clear chalaziferous albumen at the point where each chalaza is attached. Usually when the infundibular (i.e., blunt end) chalaza lies free in the albumen or has become invisible this button marks the corresponding end of the chalazal axis. Again there are eggs which show both 
chalazæ unattached and in these there is no chalazal axis. The two chalazæ are frequently unequal in size or form, as was said above (p. 327). Thus only the cloacal chalaza may be forked at the end, or it may be merely longer or stouter than the infundibular one. On the other hand, the two may be indistinguishable. The following table shows the absolute and relative frequencies with which these were encountered and it gives also the frequencies of various kinds of abnormal eggs.

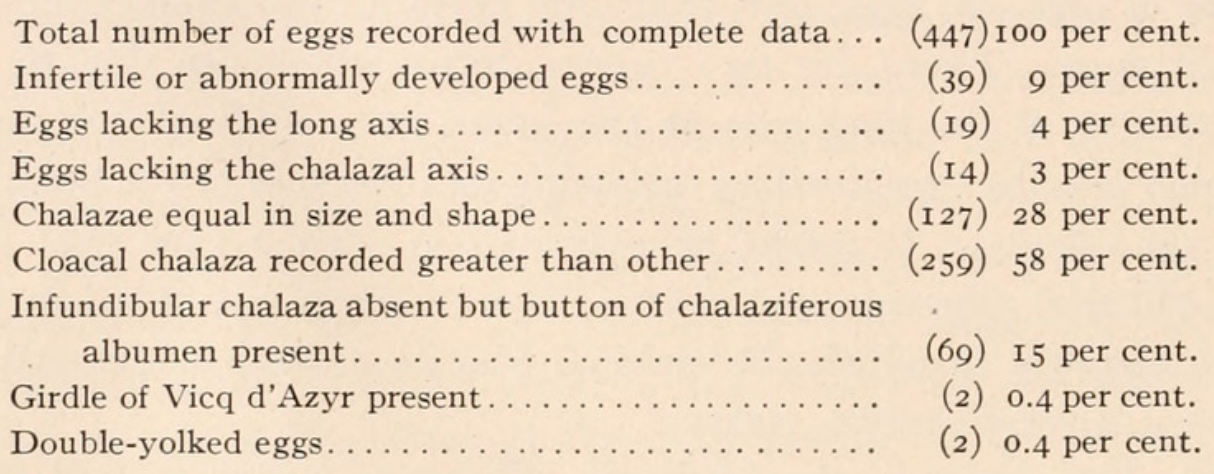

It should be said that of the I9 cases which had no long axis 5 were either infertile or had abnormal embryos. This was true of 3 which lacked the chalazal axis. On the other hand, irregular chalazæ are much more frequent. Patterson (1909) reported 8 per cent. such eggs, including those which lacked one chalaza. If we make a similar category in the present records, including those eggs which have only a button at the infundibular end of the long axis and those with accessory and unattached chalazæ we get 9I cases (20 per cent.). I have records of only two eggs which had both long and chalazal axes abnormal; approximate measurements of the axis angle can be made in 98 per cent. of normal pigeons' eggs and accurate measurements can be made in 88 per cent. of cases. When the long and chalazal axes do not coincide, as occurs in 2 per cent. of the eggs, they may diverge from 4 to $20^{\circ}$, very rarely more. Most of these were otherwise normal and it should be borne in mind that the same is true of most eggs which lack long or chalazal axes. This emphasizes the fact that this relation is an effect, not a cause; it is simply the morphological expression of the presence of certain axes of bilaterality. The embryo may develop normally whether this expression is perfect or not.

We may say then, that in the pigeon's egg the chalazæ vary 
considerably, although extreme irregularities are rare (3 per cent.). Since the two chalazæ were indistinguishable in only 28 per cent. of cases we may say that in the majority of eggs more albumen is secreted below the ovum than above it when it first enters the duct and consequently the cloacal (pointed end) chalaza is frequently larger than the other. Unfortunately I have recorded only $\mathrm{I} 4$ of the instances when this was found to be the case in early oviducal eggs.

\section{General Conclusions.}

I. The older literature on the bird's egg has been grossly neglected by recent students of this subject.

2. The bilaterality of this egg finds expression in two axes of bilateral symmetry: the embryonic axis and the principal egg axis which is defined for the most part by characters of the secondary egg envelopes.

3. These axes are definitely related to each other in such a way that the right side of the embryo is nearer one of the ends of the principal axis than the other.

4. This holds for the eggs of all the species that have been examined with this relation in mind: viz., the domestic fowl, the common pigeon, the emu, the duck and perhaps the sparrow.

5. The actual angle between the two axes (axis angle) is subject to great variation.

6. Conclusions from observations on the pigeon's egg.

(a) The axis angle was found to vary almost $180^{\circ}$ but 85 per cent. of the cases fell between 45 and $90^{\circ}$.

(b) Eggs obtained from a single bird vary much less, the maximum variation being from 32 to 68 per cent. of that found in eggs from the entire flock.

(c) Extreme variations of the axis angle are probably due to imperfect orientation of the ovum in the oviduct, to abnormalities in its action or to irregularities during the final growth period of the oöcyte. Such eggs usually show irregularities either of long axis or chalazæ.

(d) The angle in normal eggs of a given bird, while usually restricted to a range of $45^{\circ}$ is apparently determined within this range by the laws of chance during oögenesis. 
(e) In about one half the clutches studied the angles of the first and second eggs agreed closely. This is a matter of great practical importance in the study of ovarian and oviducal eggs.

$(f)$ Inversions are due either to the reversal of the long axis of the ovum at about the time of ovulation or they may be due to the reversal of the polarity of the oöcyte early in oögenesis.

(g) The long axis could be identified in 96 per cent. of the eggs studied, the chalazal axis in 97 per cent. The two coincided in 98 per cent. of normal eggs.

(h) The chalazae were found abnormal in only 3 per cent. of cases but more or less atypical in 20 per cent. of cases.

(i) In $5^{8}$ per cent. of the eggs the cloacal (i.e., pointed end) chalaza was strikingly larger than the other.

I am indebted to the Librarians of the Surgeon General's library and of the Harvard Library for the loan of several of the older works mentioned and to Miss E. Dickenson of the University of Chicago Library for help in tracing many of the earlier references.

\section{BIBLIOGRAPHY.}

The titles marked with an * do not appear or are inaccurately cited in the bibliography of Keibel und Abraham's Normentafel or the corresponding work of Grosser und Tandler.

Aldrovanus, U.

I646 Opera Omnia Lib. I-III. Bononiæ, I646.

Aristotle (324-322 B.C.)

De generatione animalium. Translated by A. Platt. Oxford, I9Io.

v. Baer, C. E.

I828-'88 Ueber die Entwickelungsgeschichte der Thiere-Beobachtung und Reflexion. I. Theil, I828; II. Theil, no. I, I837; II. Theil, no. 2, I888 (Ed. L. Stieda). Leipzig.

\section{Barry, M.}

I838 Researches in embryology, Ist Series. Philosophical Transactions, p. 301. London.

Balfour, F. M.

See Foster \& Balfour.

Bartelmez, G. W.

1912 The Bilaterality of the Pigeon's Egg. Jour. Morph., Vol. 23, p. 269.

Berthold, A. A.

1829 Ueber die Bildung und den Nutzen der Hagel (Chalazæ) im Vogeley. Isis, I 829 , p. 404.

Blanc, L.

I8́92 Note sur l'influence de la lumière sur l'orientation de l'embryon dans l'œuf de poule. Compt. Rend. Soc. Biol., T. 44, p. 774. 


\section{Blount, Mary}

r909 The Early Development of the Pigeon's Egg with Especial Reference to Polyspermy and the Origin of the Periblast Nuclei. Jour. Morph., Vol. 20, p. I.

*Bonnet, C.

I762 Considérations sur les corps organisés. Genéve (from Collection complete des œuvres. T. VI., p. 4I2).

Conklin, E. G.

I903 The Cause of Inverse Symmetry. Anat. Anz., Bd. 23.

Coste, M.

I847 Histoire général et particulière du développement des corpes organisés. Paris.

Curtis, M. R.

I9r I An Accurate Method for Determining the Weight of the Parts of the Eggs of Birds. Maine Ag. Exp. Stat. Annual Report, I9I1, pp. 93-II2.

I9I4 Factors Influencing the Size, Shape and Physical Constitution of Eggs. Arch. f. Entwkm., Bd. 39, p. 217.

I9I5 The Relation of Simultaneous Ovulation to the Production of Double Yolked Eggs. Jour. Ag. Research, Vol. 3, p. 376.

Dalton, J. C.

I88 I The Position of the Embryo in the Fowl's Egg. Medical Record, v. 20, p. 589 .

Darest, C.

I89I Recherches sur la production artificielle des monstrosities. Ed. II., Paris.

*Dutrochet, $\mathbf{H}$.

I8r9 Histoire de l'oeuf des oiseaux avant la ponte. Jour. de Physique, Chem., Hist., Nat., etc., T. 88, p. I70. Review: Deut. Arch. Physiol., Bd. 6, p. 379 .

Duval, M.

r884 De la formation de blastoderme dans l'œuf des oiseaux. Ann. des Sc. nat. Zoöl., Ser. 6. T г8. p. I.

r889 Atlas d'Embryologie. Paris.

*Erdmann

I886 Briefliches über Eierlegen. Jour. f. Ornith., Bd. 34, p. 406.

Fabricius ab Aquapedente, Hier.

1625 De formatione ovi et pulli. (From opera omnia Anat. et Physiol., I738 ed., B. S. Albini.)

Féré, Chas.

r894 Note sur l'influence des enduits partiels sur l'incubation de l'œuf de poule. C. R. Soc. Biol., I894, p. 65.

I896 Note sur l'orientation et sur l'allure du développement de l'embryon de canard. C. R. Soc. Biol., I 896.

I897 Note sur le développement et la position de l'embryon du poulet dans les œufs a deux jaunes. C. R. Soc. Biol., I897, p. 858 .

I897 Note sur les changements de position et de forme du jaune de l'œuf de poule pendendant l'incubation. C. R. Soc. Biol., I897.

$\mathbf{9 0 0}$ Note sur la multiplicité des causes des variations de l'embryon du poulet. Jour. Anat. Physiol., Ann. 36, p. 2 I0. 


\section{Ferret et Weber}

r904 Influence de la piqûre des enveloppes secondaires de l'oeuf de poule sur l'orientation de l'embryon. Ar. zoöl. exp. gén., Sér. 4, T. 2. Notes et Revues, p. lx.

Foster, M., and Balfour, F. M.

I874 The elements of embryology. London.

Galeb, O.

I879 De l'oeuf dans la série animale. Paris.

Grosser, O., und Tandler, J

I909 Normentafel zur Entwicklungsgesichte des Kiebitzes (Vanellus cristatus). Jena.

Haller, Alb.

I758 Sur la formation du coeur dans le poulet. Lausanne.

Harper, E. H.

I904 The Fertilization and Early Development of the Pigeon's Egg. Am. Jour. Anat., Vol. 3, p. 349

Harvey, William

I65 I Exercitationes de generatione animalium. London.

Haswell, W. A.

r887 Observations on the Early Stages in the Development of the emu (Dromæus novæ hollandiæ). Proc. Linn. Soc. New South Wales, II. series, Vol. 2, p. 577 .

\section{Hertwig, O.}

I906 Handbuch der vergleichenden und experimentellen Entwicklungs-

His, W. geschichte der Wirbelteire. Bd. I, Jena.

I868 Untersuchungen über die erste Anlage des Wirbeltierleibes. Die erste Entwicklung des Hünchens im Ei. Leipzig.

Home, E.

I822 On the Changes the Egg Undergoes During Incubation. Phil. Trans., Vol. II2, p. 339. London.

*Jasse, J.

I886 Aus Bericht der Ornith. Ges., Jour. f. Ornith. Bd. 34 p. I24.

Jörg, J.

I8I5 Die wieblichen Zeugungsorgane und das Ei in den verschiedenen Thierklassen. Leipzig.

Keibel, F., und Abraham, $\mathrm{K}$.

I900 Normentafel zur Entwicklungsgesichte des Huhnes. Jena.

Kionka, H.

I894 Die Furchung des Hühnereies. Anat. Hefte, Bd. 3, p. 429.

Kölliker, A. v.

I86I Die Entwicklungsgeschichte des Menschen und der höheren Wirbelthiere. Leipzig.

*König-Warthausen, $\mathrm{R}$.

I885 Die Gestalt der Vogeleier und deren Monstrositäten.

*Kutter, $\mathbf{F}$.

r878 Betrachtung über Systematik und Oölogie vom Standpuncte der Selectionstheorie. II. Teil, Jour. f. Ornith., Bd. 26, p. 300.

r880 Bermerkungen über einige oölogische Streitfragen. Jour. f. Ornith., Bd. 28 , p. I57. 
Landois, H.

I877 Missbildungen bei Hühnereiern.

Langly, W.

I674 Observationes quædam de generatione animalium. Amsterdam.

Leuckart, $\mathbf{R}$.

I853 "Zeugung" in R. Wagner, Handwörterbuch der Physiologie.

Léveillé, J. B. F.

I799 Dissertion physiologique sur la formation des foetus dans les mammifères

Lillie, F. R

et dans les oiseaux. Jour. de Physique, Ann. 7 (de la Republique), p. 386.

I908 The Development of the Chick. New York.

Locy, Wm

I908 The Makers of Biology. New York.

Maitrejean, A

I722 Observations sur la formation du poulet. Paris.

Malpighi, $\mathbf{M}$

I672 De formatio pulli in ovo dissertatio.

I675 Anatome plantarum, cui subjungitur appendix iteratus et auctas ejusdem auctoris de ovo incubato observationes continens. From Opera Omnia, R. Scott, London, I686.

Marshall, A $\mathbf{M}$

I893 Vertebrate Embryology. London.

*Mayer, F J C.

r865 Ueber das Ei der Vögel und Reptilien. Nova Acta Acad. Nat. Curios. Dresden, Bd. 32.

Meckel, H. von Hemsbach

I85I Die Bildung der für die partielle Furchung bestimmte Eier der Vögel im Vergleich mit den Graafschen Follikel und die Decidua des Menschen. Zeit. f. Wiss. Zoöl., Bd. 3, p. 420.

Mertens, $\mathbf{N}$.

I830 Beiträge zur Kenntniss der Fetushüllen im Vogelei. Meckel's Ar. f. Anat. u. Physiol., I830.

M urray, J.

r826 On the temperature of the egg of the hen, in relation to its physiology. Edinb. Philosoph. Jour., no. 27.

* Nasse, $\mathrm{O}$.

I862 Die Schleimhaut der inneren weiblichen Geschlechtsteile im Wirbelthierreich. (Inaug. Diss.) Marburg.

Nathusius, W. v.

I868 Ueber die Hüllen welche den Dotter des Vogeleis umgeben. Zeit. f. Wiss. Zoöl., Bd. I8, p. 225.

I893 Die Entwicklung der Schale und Schalenhaut des Hühnereies im Oviduct. Ibid., Bd. 55 , p. 576 .

I885 Besteht eine ausnahmslose Regel über die Lage der Pole des Vogeleies im Uterus im Verhältnis zur Kloakenmündung? Zoöl. Anz., Bd. 8, p. 4I5.

I885 Ueber die Lage des Vogeleies im Uterus. Ibid., Bd. 8, p. 7 I3.

Pander, Ch.

I8I7 Historia metamorphoseos, quam ovum incubatum prior quinque diebus subit. Wiresburgi. The same in German and illustrated.-Beiträge zur Entwicklungsgeschichte des Hühnchens im Eye. Würzburg, I8I 7 . 
*Paris, J. A.

I8I I Some Remarks on the Physiology of the Egg. Trans. Linn. Soc. London, Vol. 10, p. 304.

Patterson, J. T.

I909 Gastrulation in the Pigeon's Egg. Jour. Morph., Vol. 20, p. 65.

I9 Io Studies on the Early Development of the Hen's Egg, Pt. I. Jour. Morph., Vol. 2I, p. IOI.

Pearl, R., and Surface, F. M.

I9II A Biometrical Study of Egg Production in the Domestic Fowl, Pt. II. Seasonal Distribution.

I9I4 Pt. III. Variation and Correlation in the Physical Characters of the Egg. U. S. Dept. Agricult. Bureau of Animal Industry, Bull. I Io.

Pearl, R., and Curtis, M. R.

I9I2 Studies on the Physiology of Reproduction in the Domestic Fowl, Pt. V. Data Regarding the Physiology of the Oviduct. Jour. Exp. Zoöl., v. I2, p. 99 .

I9I4 Pt. VIII. On Some Physiological Effects of Ligation, Section or Removal of the Oviduct. Ibid. v. I7, p. 394.

Petit, Mme.

I9oo Sur la sexualité des embryons de poule en rapport avec la forme de l'œuf. C. R. Assoc. Fr. Adv. Sc., Sess. 28, p. 276.

Pfeil, C.

I823 De evolutione pulli in ovo incubato. Dissert. Berolini.

Purkinje, J. E.

1825 Observata nonnulla ad ovi avium historiam ante incubationem.

1830 Symbolæ ad ovi avium historiam ante incubationem. Lipsiæ. (This is an enlarged second edition of the above with improved illustrations.)

Rabaud, E.

1908 La position et l'orientation de l'embryon de poule sur le jaune. Ar. Zoöl. Ex. Gen., 4e Sér., T. 9, p. I.

Riddle, $O$.

I9I I On the Formation, Significance and Chemistry of the White and Yellow Yolk of Ova. Jour. Mroph., v. 22, p. 455.

1912 Preliminary Chemical Studies on Male and Female Producing Eggs of Pigeons. Science, N. S., Vol. 35, p. 462.

I9I4 The Determination of Sex and Its Experimental Control. Bull. Am. Acad. Med., Vol. I5, No. 5 .

Ryder, J. A.

I893 The Mechanical Genesis of the Fowl's Egg. Proc. Am. Philos. Soc., v. 3I, p. 201.

Samter, J.

I853 Nonnulla de evolutione ovi avium donec in oviductum ingrediatur. Dissert. Halis.

\section{Sonnenbrodt,}

I908 Die Wachstumsperiode der Oöcyte des Huhnes. Ar. f. Mik. Anat., Bd. 72 , p. 4I 5 .

\section{Spangenburg, G.}

I813 Disquisitio inauguralis anatomica circa partes gentiales fœmineas avium. Goettingen. 


\section{Tarchanoff, J R.}

I884 Ueber die Verschiedenheiten des Eiereiweisses bei gefiedert geborenen (Nestflüchter) und nackt geborenen (Nesthocker) Vögeln u. s. w. Ar. f. d. ges. Phys., Bd. 33, p. 303.

\section{Taschenberg, $\mathrm{O}$.}

I885 Zur Frage über die Entstehung der Färbung der Vogeleierschalen. Zoöl. Anz., Bd. 8, p. 243.

* I894 Die Entstehung der Färbung der Vogeleier. Zoöl. Anz., Bd. I 7, p. 304. Thompson, Allen

I839? Article "Ovum," Cyclopedia of Anatomy and Physiology. I839-I847. Tredern, L. S. ab.

I808 Dissertatio inauguaralis medica sistens ovi Avium historiæ et incubationis prodromum. Jenæ.

Valentin, G.

r835 Handbuch der Entwickelungsgeschichte des Menschen u. s. w. Berlin.

Vicq d'Azyr

I805 Oeuvres (recueillies par J. L. Moreau) T. IV., p. 388 ss. “Fragmens sur l'anatomie et la physiologie de l'œuf."

*Wicke

Ueber das pigment in den Eischalen der Vögel. Naumannia.

Wickmann, $\mathrm{H}$.

*1893 Die Entstehung der Färbung der Vogeleier. Münster.

I895 Die Lage des Vogeleis vor und während der Geburt. Jour. f. Ornith., Bd. 44 , p. 8 I.

Wolff, C. F.

I764-1766 De formatione Intestinorum.

I8I 2 Ditto übersetzt von J. F. Meckel. 


\title{
STUDIES ON THE BIOLOGY OF PARA- COPIDOSOMOPSIS.
}

\author{
IV. The Asexual Larve. ${ }^{1}$
}

J. T. PATTERSON.

I. INTRODUCTION.

In 1906 Silvestri $^{2}$ reported in his paper on the development of Litomastix truncatellus the discovery of a curious type of larva, which he regards as asexual. According to Silvestri, the egg of Litomastix produces a thousand or more sexual larvæ and a variable number of these so-called asexual larvæ. The sexual larva undergoes metamorphosis and produces the adult male or female insect. The asexual larva, which dies without undergoing metamorphosis, is characterized by the absence of certain important organs, including the reproductive system.

Silvestri has suggested the possibility that these larvæ may be asexual because of the absence of germ cells. In studying the eggs of two monembryonic species he found that the so-called nucleolus is distributed to the germ cells alone, thus serving as a "keimbahm-determinant." The nucleolus is also present in the egg of Litomastix. In the early cleavage stages the nucleolus is included in one of the first four blastomeres, where it breaks down and its contents becomes evenly scattered throughout the cytoplasm. The presence of the nucleolar material retards the subsequent divisions of this blastomere. However, Silvestri was unable to follow the history of this particular cell beyond two divisions, that is, four cells. He suggests that during the course of the development of the polygerm, embryos which receive descendants of the single blastomere possessing the nucleolar

1 Contribution from the Zoölogical Laboratories of the University of Texas, No. 140.

${ }^{2}$ Silvestri, F., I906, “Contribuzioni alla conoscenza Biologica degli Imenotteri Parassiti. I., Biologia del Litomastic truncatellus." Ann. d. Regia Scuola Superiore di Agricoltura di Portici, Vol. VI., pp. I-5I. 
material become sexual larvæ, while those failing to receive such descendants become asexual larvæ.

Various suggestions have been offered to account for the presence of the so-called asexual larvæ in Litomastix. Some have suggested that they may not arise from the egg of Litomastix at all, but are larvæ belonging to an entirely different species. Thus Wheeler ('Io, p. 406) ${ }^{1}$ expresses doubt as to Silvestri's interpretation in the following language: "First, the asexual larvæ figured and described by this investigator are suspiciously like certain very young ichneumonid larvæ, and as their development is not satisfactorily traced to the same cellmasses from which the sexual Copidosoma larvæ arise, it is not improbable that the two larval forms really belong to two very different parasites. In other words, Silvestri's Plusia caterpillars were probably infested with ichneumonid in addition to Copidosoma larvæ. Second, I have been unable to find any larvæ of the asexual type in a number of American Plusia gamma caterpillars which were heavily infested with Copidosoma truncatellum. Third, as in many species of Chalcididæ larvæ of Silvestri's sexual type are able by their own endeavors to break down and assimilate the tissues of their host, it seems improbable that a single species should have developed a peculiar sexless and moribund larva for this particular purpose."

The subject clearly needs reinvestigation. In studying the biology of Paracopidosomopsis I have found the same sort of larvæ as those described by Silvestri for Litomastix. An opportunity is thus afforded to restudy the question. In the present paper only a brief history of the asexual larvæ will be given. As soon as sufficient material can be secured a detailed account of the cytology and embryology of both types of larvæ will be published.

The material used has been collected here at Austin during the last three years. The species, Paracopidosomopsis floridanus Ashmead, is very similar to Litomastix truncatellus. It lay its egg in the egg of the common cabbage looper, Autographra brassica. The parasitic egg develops in the body cavity or tissues

1 Wheeler, W. M., I9ro, "The Effects of Parasitic and Other Kinds of Castration in Insects," Jour. of Experimental Zoölogy, Vol. 8, pp. 377-438. 
of the Autographra caterpillar. By the time the caterpillar reaches the stage for pupation, the larval parasites consume its entire contents, leaving only the skin of the host which later hardens to form the mummified carcass containing the parasitic pupæ. Since the parasites readily emerge in the laboratory the species is very favorable for experimental studies.

Whenever the infection is heavy an abundance of material can be secured from the field. But in order to avoid the possibility of the host egg or larva becoming infected by a species other than Paracopidosomopsis, I have used almost exclusively material reared in the laboratory under experimental control. The only exception in this paper is Fig. I2, Plate II.

In all of the experiments the moth eggs have been protected from parasites by having the moths lay their eggs under a belljar. The fresh eggs thus obtained are then parasitized. The female parasite has been permitted to make but a single oviposition in each moth egg. The parasitized eggs and the larvæ developing from them have been protected from subsequent infection by keeping them in a closed vessel from which all parasites were scrupulously excluded. Under these conditions of protection, I find that the parasitic egg produces asexual as well as sexual larvæ. These curious larvæ develop irrespective of whether or not the female parasite laying the egg is virgin or impregnated.

From the standpoint of experimental work, the material presents one difficulty. In a previous paper, I have shown that the female, in about two cases out of three, deposits two instead of one egg at a single oviposition. It is frequently difficult, especially in late stages, to determine in a given parasitized caterpillar whether one is dealing with a case involving the product of one or of two parasitic eggs. In early stages this difficulty seldom presents itself, because if two polygerms are present they nearly always lie some distance apart in the tissues of the host.

The age of any stage, referred to in this paper, is based upon the time of oviposition. There is, however, considerable variation in the rate of development of different eggs. Furthermore, temperature greatly influences the rate of development. In August and September about 28 to 30 days elapses between the 
laying of the egg and the emergence of the adult insects; whereas in the cooler months of October and November, it takes about 40 to 45 days.

\section{The Early Polygerm Stage.}

It will be sufficient, for the purposes of this paper, to give only a brief statement concerning the early development of the egg. The freshly deposited egg is a pear-shaped structure, with a large conspicuous nucleus situated toward the anterior or narrower end, and a deeply staining nucleolus lying at the posterior or broad end. Immediately after the egg is deposited, the nucleus undergoes the typical maturation divisions. The first polar body nucleus divides simultaneously with the second maturation division. There is thus produced an egg nucleus and three polar-body nuclei. The former then moves to the broad end of the egg, and whether fertilized or not, produces the cleavage cells. One of the first four blastomeres receives the nucleolus, the presence of which somewhat retards the subsequent divisions of this particular cell. By the time the other three blastomeres have produced about twenty-four cells, the one containing the nucleolar substance has produced but four. Beyond this point its history can not be followed. All of these early blastomeres constitute the embryonic cells. They occupy the posterior twothirds of the egg.

In the meantime, the polar-body nuclei fuse to form a single polar nucleus, which continues to divide until the protoplasm of the anterior end of the egg is filled with nuclei. The anterior third of the egg thus becomes syncytial in character, and may be called the polar region. In slightly later stages the polar region completely surrounds the mass of embryonic cells, and in stages still more advanced, it forms a nucleated membrane.

About seventy hours after oviposition, the nucleated membrane begins to invade the embryonic cells by the formation of trabeculæ, which divide the embryonic cells into several groups, or primary masses (Fig. I). During the formation of these masses, or very shortly thereafter, the young polygerm elongates in the direction of the long axis of the egg (Fig. 2). In addition to the nucleated membrane, each primary embryonic mass develops a 
second envelope, which lies just inside the nucleated membrane. Apparently, this inner envelope is formed from the peripheral layer of cells of the embryonic mass (Fig. 3). The primary embryonic masses produce secondary masses by fission. A very clear case of division is seen in Fig. 8, on the right.

\section{Origin of the Asexual Larve.}

The first sign of asexual larvæ appears in young polygerms between seventy-five and eighty hours old. One of the youngest stages observed is shown in Fig. 3. An asexual embryo lies at the upper end of the figure, and is distinguishable from the primary masses by two features of its organization. First, the asexual embryo is composed of a large number of relatively small, closely packed cells, whereas a primary mass is composed of a few large cells, showing no definite arrangement. Second, the inner of the two envelopes surrounding the embryo is decidedly hicker than the corresponding membrane of a primary mass. Both of these features become more evident in slightly older stages, such for example, as that shown in Fig. 4. In this specimen the asexual embryo stands in striking contrast to the rest of the polygerm. Furthermore, the constriction of the nucleated membrane, or outer envelope, has all but cut off the embryo from the primary masses. A similar condition is seen in Fig. 5 .

At this point it will be well to recall Silvestri's account of the origin of the asexual larvæ in Litomastix. The polygerm of Litomastix, soon after the nucleated membrane is established, begins to show differentiation into two distinct regions. The anterior region is made up of large and small cells, while the posterior region is composed of small cells only. A constriction appears in the nucleated membrane, which finally separates these two regions. Silvestri names the anterior region the massa germinigena, and the posterior the massa monembrionale. The latter subsequently differentiates into a single asexual larva. In the course of further development, the massa germinigena gives rise to a few secondary monembryonal masses, which differentiate into asexual larvæ, and to a large number of other masses. This is accomplished by constrictions in the polygerm. The masses continue to multiply by constrictions, and may from 
time to time produce a few asexual embryos; but a large majority of them differentiate into sexual embryos.

Some phases of the development of Paracopidosomopsis are directly comparable to certain stages of Litomastix. The formation of the primary masses and their subsequent mode of multiplication is very similar to the history of the massa germinigena. The chief difference is the early formation of a monembryonal mass in Litomastix, for which there is no counterpart in Paracopidosomopsis. According to Silvestri the young polygerm always differentiates into a monembryonal mass and the massa germinigena. In the American species a single asexual embryo may be found at an early stage (Figs. 3, 4, 5), but this is by no means the universal rule. In Figs. 6, 7, 8 are shown three well-developed polygerms in which no asexual embryos have as yet appeared. It is not certain whether such polygerms later produce asexual larvæ, although the evidence seems to indicate that at least some of them do. In some cases two or more asexual embryos may develop simultaneously in the very young polygerm. The specimen on the right of Fig. 9 has two such embryos, and Fig. II illustrates a similar case. The polygerm shown in Fig. I3 has given rise to four asexual embryos, all in the same stage of development, but situated in different parts of the mass.

These facts indicate clearly that the polygerm of Paracopidosomopsis may give rise to one or more asexual embryos at a very early stage of differentiation, but there is no such regularity in the formation of a single monembryonal mass as reported by Silvestri for Litomastix.

\section{Dissociation of the Polygerm.}

We have already mentioned the fact that the primary masses divide to produce the secondary masses. An early phase of this process is seen in Fig. 6. The primary mass at the extreme left and the one lying on the lower side has each undergone several divisions. There are at least four secondary masses visible in the median section of each primary center. In a still younger stage, Fig. 8 , the primary mass on the right is just completing the first division. At this stage of development each secondary mass consists of one or more large central cells and an indistinct 
peripheral layer of smaller cells. Surrounding the mass is a thin envelope formed from the trabeculæ of the nucleated membrane. The large central cells are clearly the embryonic cells proper.

The multiplication of secondary masses to produce other masses continues for a long period, at the close of which the final products of division develop into embryos. However, during the course of development, usually early in the period of multiplication, the polygerm fragments or dissociates, the secondary masses becoming widely scattered throughout the body cavity of the caterpillar. The point at which dissociation takes place varies greatly in different cases. It may occur at the close of the third day, or it may be delayed until as late as the tenth or eleventh day. Indeed, in some cases, the polygerm does not completely dissociate until the larvæ are ready to be set free in the body cavity of the host. Apparently, the dissociation is in part controlled by the relation of the polygerm to the host tissues. If the polygerm lies free in the body cavity, or in loose tissue, dissociation will occur very early; but if it is imbedded in fat or other dense tissue, the dispersal of the secondary masses may be greatly delayed.

The polygerm on the left of Fig. 9, although only seventyseven hours old, has already begun to fragment. Several secondary masses lie some distance from the main body of the polygerm. Two of these appear in the photograph. The polygerm seen in Fig. $\mathrm{I}_{3}$ is ninety-five hours old, and lies free in the body cavity. Dissociation is well advanced, and secondary masses are widely dispersed. In addition to the secondary masses, it has formed four asexual embryos at as many different points. The polygerm in Fig. I I is eleven days old. It was dissected from the fat tissue of the host. It contains a large number of secondary masses, some of which are beginning to break loose from the main mass, and two conspicuous asexual embryos. These few cases will serve to show the variation in the time at which dissociation begins.

V. Development and Fate of the Asexual Larve.

While some polygerms produce asexual embryos at a very early stage (Figs. 3, 4, 5, 9, I3), nevertheless the majority of such 
embryos do not appear until after dissociation has taken place. The production of asexual larvæ in a given polygerm is not confined to a single period of development, but is a continuous process, extending from the third to about the fifteenth day. Sections of practically every polygerm from twelve to fourteen days old will show asexual individuals in various stages of development, from young embryos to fully developed larvæ.

The method of their development in the American species is very similar to that for Litomastix as described by Silvestri. The main difference is that they frequently appear in groups, instead of arising singly from certain of the secondary masses. This is also true for some of the early cases (Figs. 9, II). Fig. I4 is a section passing through a group of asexual embryos imbedded in adipose tissue. In the upper right-hand corner of the figure is a group of secondary masses about on the point of developing into sexual embryos. They are easily distinguishable from the asexual embryos by their comparatively small size. Several other series show this same condition. Single embryos or small groups of two or three do, however, appear in some of the series.

After the period of multiplication of secondary masses is closed, that is in stages fourteen or fifteen days old, the body cavity of the host contains many groups of asexual embryos (Figs. I5, I6, I2) as well as groups of young asexual larvæ. In each of two series a group of ten or twelve individuals was found. There are also found free asexual larvæ (Figs. 20, 21, 22), and some that are on the point of being set free from the capsule (Fig. I8). That single asexual larvæ may develop in conjunction with a group of sexual embryos is clearly evident in two instances. In Fig. I7 a young asexual larvæ is closely associated with a group of sexual embryos, and in Fig. I9 a large asexual larvæ, just freed from its capsules, is still attached to a mass of embryos.

The frequent appearance of asexual embryos or larvæ in groups suggests that, like the sexual embryos, the individuals of a group have a common origin, probably arising through the division of a single secondary mass.

Since one cannot follow the course of development of a single egg, but must depend upon series of sections, it is impossible to determine whether every polygerm eventually produces asexual 
larvæ. Dissections of a large number of infected caterpillars, twelve to fifteen days old, reveal the presence of asexual larvæ in nearly every case. It is probable that in a few cases no asexual larvæ are developed. It is also difficult to determine the exact number of asexual larvæ produced by a given egg. This is due to the fact that these larvæ are formed continuously from ths third to the fifteenth day, and those first developed degenerate before the last ones appear. The smallest number of larvæ found was one, the largest fifteen. Careful dissections of a series of infected caterpillars reared in the laboratory gave the following data on asexual embryos and larvæ:

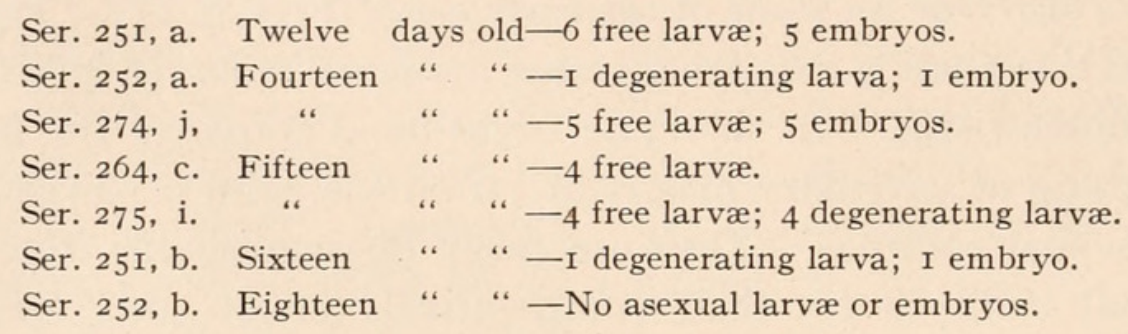

These data indicate that not more than twelve to fifteen asexual larvæ are produced by a single egg. They also show the period in which these larvæ are developed. The youngest stage containing free larvæ was twelve days old, while the oldest was sixteen days. The asexual larvæ have all degenerated by the eighteenth day. This conclusion has been verified by an extensive study of infected caterpillars from the field. No asexual larvæ have been found in caterpillars whose size indicated that they were eighteen days or older.

The general appearance of the fully developed asexual larva is shown in Figs. 20-22. I have not worked out the details of their organization, but it is clear from a study of entire mounts and sections that the reproductive system is absent. Whether, as in Litomastix, the respiratory system, circulatory system, and malpighian tubules are absent, I have not determined.

The asexual larvæ apparently do not live more than a very few days after being set free in the body cavity, probably not over three days. Free larvæ first appear on the twelfth day, and degenerating specimens are found on the fifteenth day. The last larvæ escape from their envelopes on the sixteenth day, and disappear on the eighteenth day. Without exception all asexual 
larvæ degenerate. The beginning of degeneration is marked by a foreshortening and twisting of the body (Figs. 23-25). The larva then becomes immobile and soon disintegrates (Fig. 26). So far as I can observe, the larvæ perform no function. There is no evidence that they break down the tissues of the host in preparation for assimilation by the sexual larvæ. They disappear at least a week before the sexual larvæ become free agents.

Whatever may be the underlying cause of the development of these non-viable larvæ, there is certainly no doubt as to the fact that they are formed from the egg of Paracopidosomopsis. This fact is established by the results obtained from controlled experiments in which all other parasitic species have been excluded, and by tracing their origin back to the beginning of their development in the young polygerms.

Austin, Texas,

June 20, I9I 8. 


\section{Explanation of Plate I.}

FIG. I. A median longitudinal section of a young polygerm. The egg from which this polygerm developed was about 73 hours old. The egg was laid by a fertilized female. $\times 385$.

FIG. 2. From the same lot as the preceding, but slightly more advanced in development. $\times 379$.

FIGS. 3-I0. All from sections of larvæ on the point of hatching. About 77 hours old. The eggs were laid by fertilized females. $\quad \times 389$.

FIG. 3. Longitudinal section of polygerm, showing a young asexual embryo at upper end.

FIG. 4. Same as preceding, with asexual embryo at lower end.

FIG. 5. A polygerm with asexual embryo on the right.

FIG. 6. A polygerm showing no axesual embryo.

FIG. 7. Transverse section of polygerm, showing no asexual embryo.

FIG. 8. Same as preceding. On the right is seen an embryonal mass in the act of dividing.

FIG. 9. Two polygerms in tissue of host. The one on the left has undergone partial dissociation, while the one on the right has not yet dissociated. The latter shows two asexual embryos at the upper end.

FIG. Io. Part of a dissociated polygerm, showing a well-developed asexual embryo and four embryonal masses. 


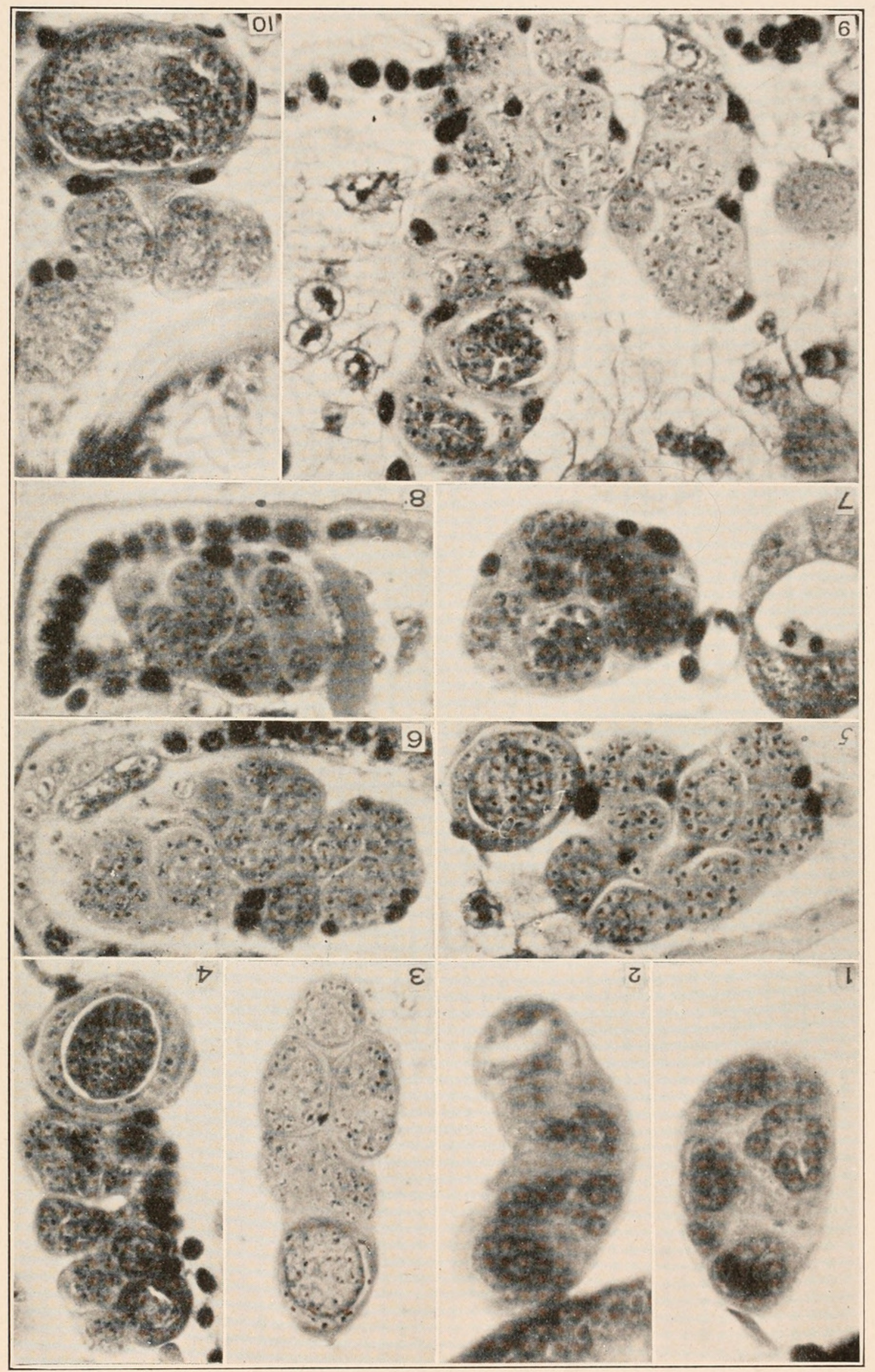






\section{Explanation of Plate II.}

FIG. II. Longitudinal section of an advanced polygerm removed from the adipose tissue of a I2-mm. caterpillar. The polygerm is II days old. The egg was laid by a fertilized female. Two large asexual embryos are shown in the upper end of the figure. $\times$ I48.

FIG. I2. A mass of sexual embryos. One of several masses removed from the body cavity of a $30 \mathrm{~mm}$. caterpillar taken from the field. $\times 4 \mathrm{I}$.

FIG. I3. Part of a longitudinal section of a polygerm in the body cavity of $5 \cdot 5$ $\mathrm{mm}$. caterpillar. The polygerm has undergone almost complete dissociation. One of the four asexual embryos present in this polygerm is seen at the right. Egg laid by fertilized female. 95 hours old. $\times 490$.

FIG. I4. Part of a dissociated polygerm, showing a group of seven asexual embryos, and a group of embryonal masses in the upper right-hand corner. All are embedded in fat tissue. The polygerm is 9 days and 23 hours old. $\times 136$. 


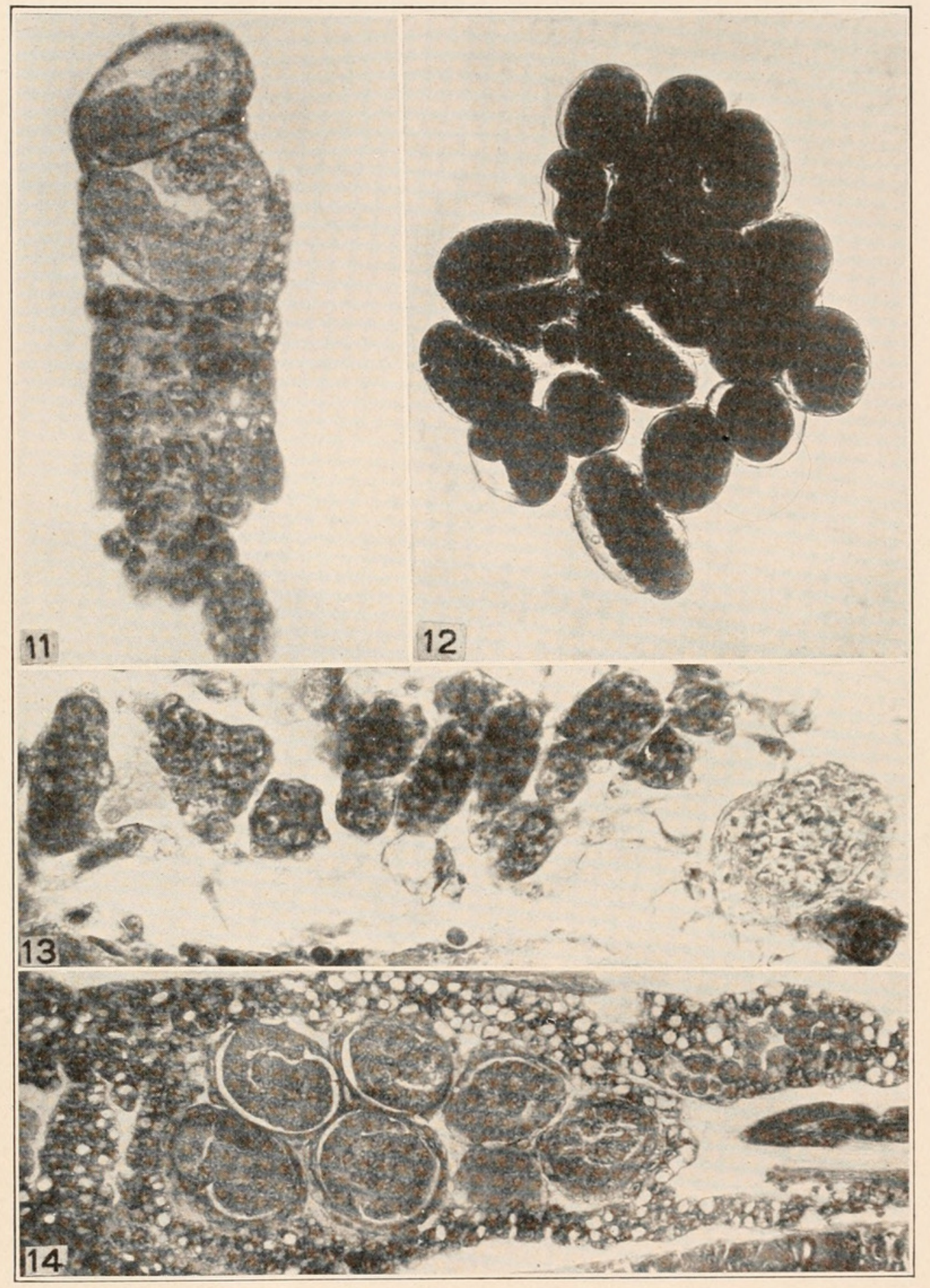

J. T. PATTERSON. 




\section{Explanation of Plate iII.}

Figs. I5, I6, I9, 22-26 are from eggs (or egg) laid by an unfertilized female. The specimens were taken from the body cavity of a half-grown caterpillar I5 days after the eggs had been deposited. The body cavity contained 4 normal and 4 degenerate asexual larvæ, in addition to many masses of sexual embryos. Figs. I 7, I 8,20 and 2I are from eggs (or egg) laid by a fertilized female. The specimens were removed from the body cavity of a $20-\mathrm{mm}$. caterpillar, I4 days after the eggs had been deposited. There were found in the body cavity of the caterpillar 6 free asexual larvæ and 4 still enclosed in their membranes, besides many masses of sexual embryos.

Figs. 15, I6. Two masses of sexual embryos. $\times$ ioo.

FIG. I7. Mass of sexual embryos with asexual embryo in capsule. $\times$ Ioo.

FIG. I8. Asexual larvæ in capsule. $\times$ ıоo.

FIg. I9. Asexual larva free from capsule but still adhering to mass of sexual embryos. $\times 88$.

FIGS. 20-22. Three asexual larvæ. $\times 88$.

FIGS. 23-26. Four degenerating asexual larvæ. $\times 88$. 


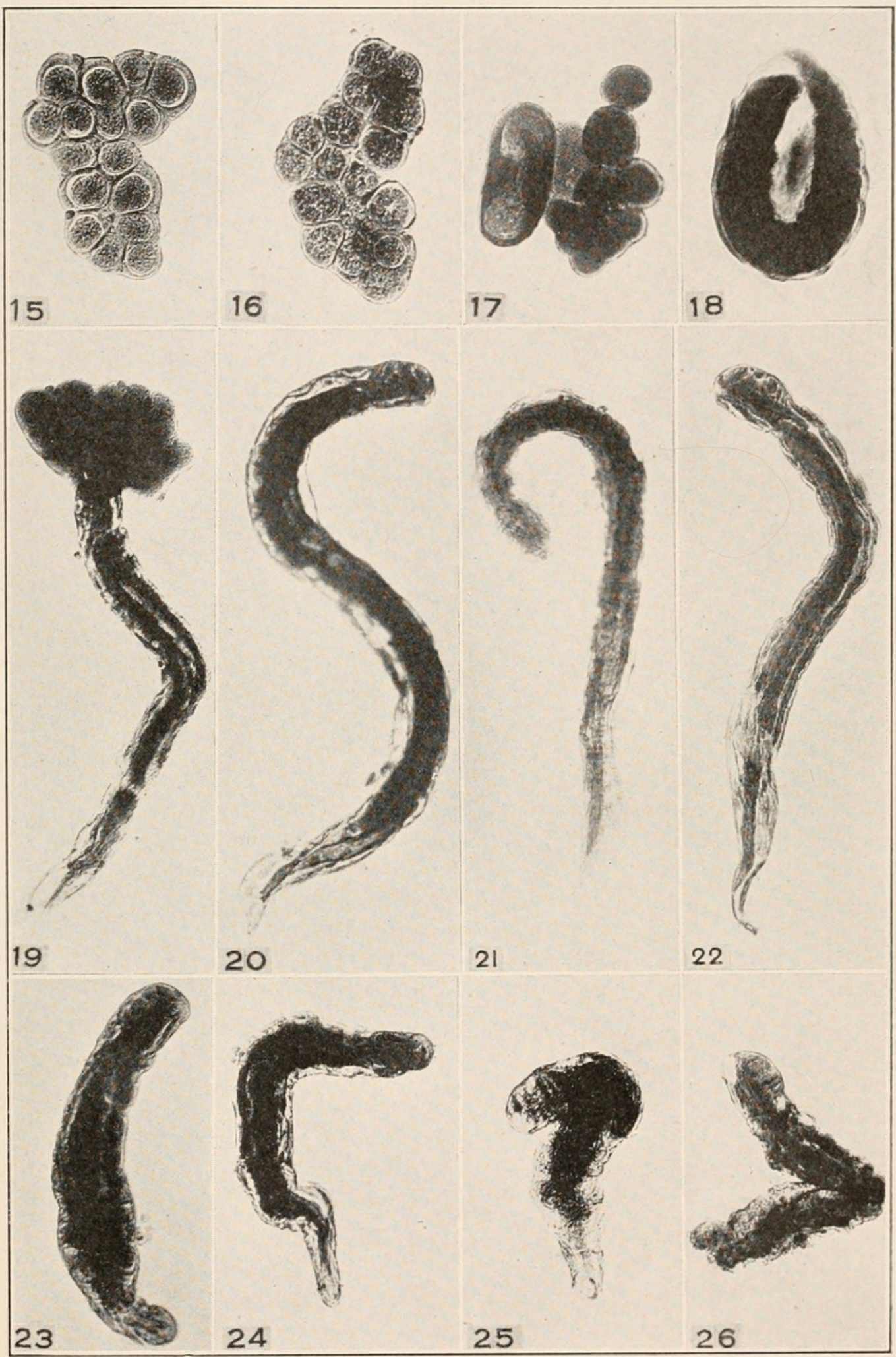

J. T. PATTERSON. 





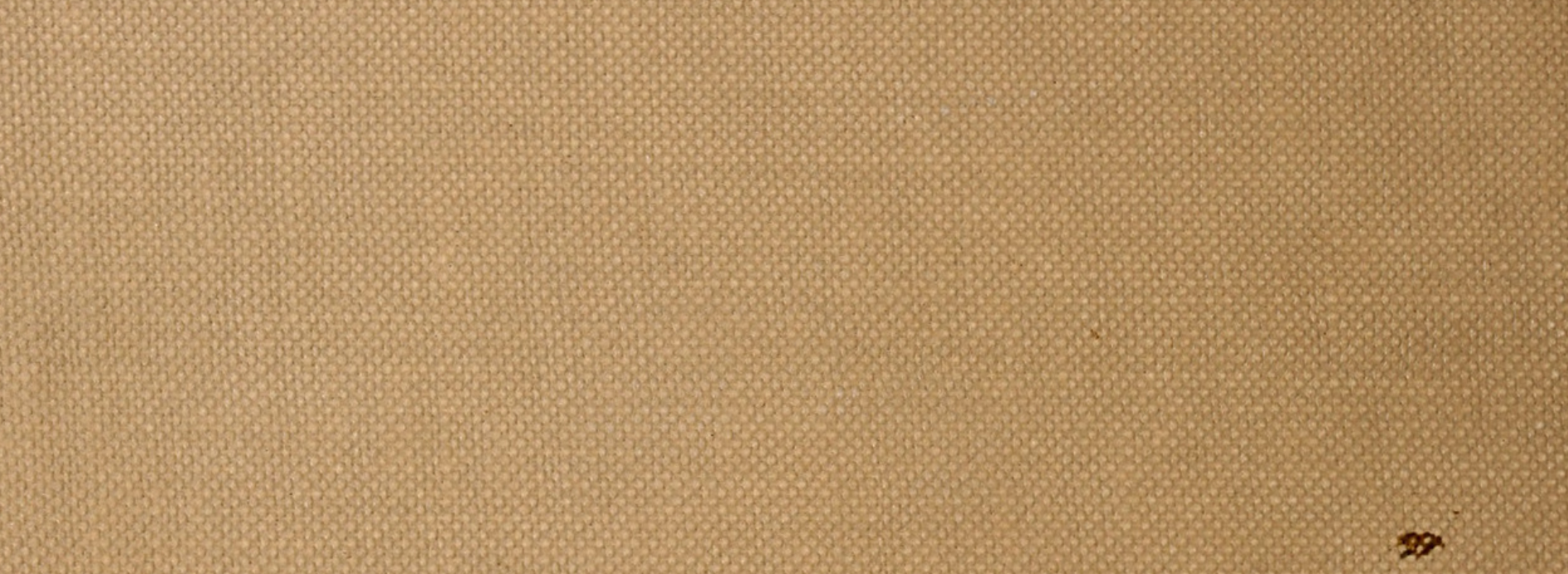
88 


\section{$2 \mathrm{BHL}$ Biodiversity Heritage Library}

Hoskins, Margaret Morris. 1918. "FURTHER EXPERIMENTS ON THE EFFECT OF HEAT ON THE EGGS OF CUMINGIA." The Biological bulletin 35, 260-276. https://doi.org/10.2307/1536293.

View This Item Online: https://www.biodiversitylibrary.org/item/16928

DOI: https://doi.org/10.2307/1536293

Permalink: https://www.biodiversitylibrary.org/partpdf/13789

\section{Holding Institution}

MBLWHOI Library

\section{Sponsored by}

MBLWHOI Library

\section{Copyright \& Reuse}

Copyright Status: NOT_IN_COPYRIGHT

This document was created from content at the Biodiversity Heritage Library, the world's largest open access digital library for biodiversity literature and archives. Visit BHL at https://www.biodiversitylibrary.org. 